DOI https://doi.org/10.25045/k.nurubay.portalhiper

ISBN 9789952536096

ORCID iD https://orcid.org/0000-0001-6958-5412

\title{
CORRAHIYYO SEMINARLARI
}

\section{Nuru Yusifoğlu BAYRAMOV}

\section{PORTAL HIPERTENZIYA}

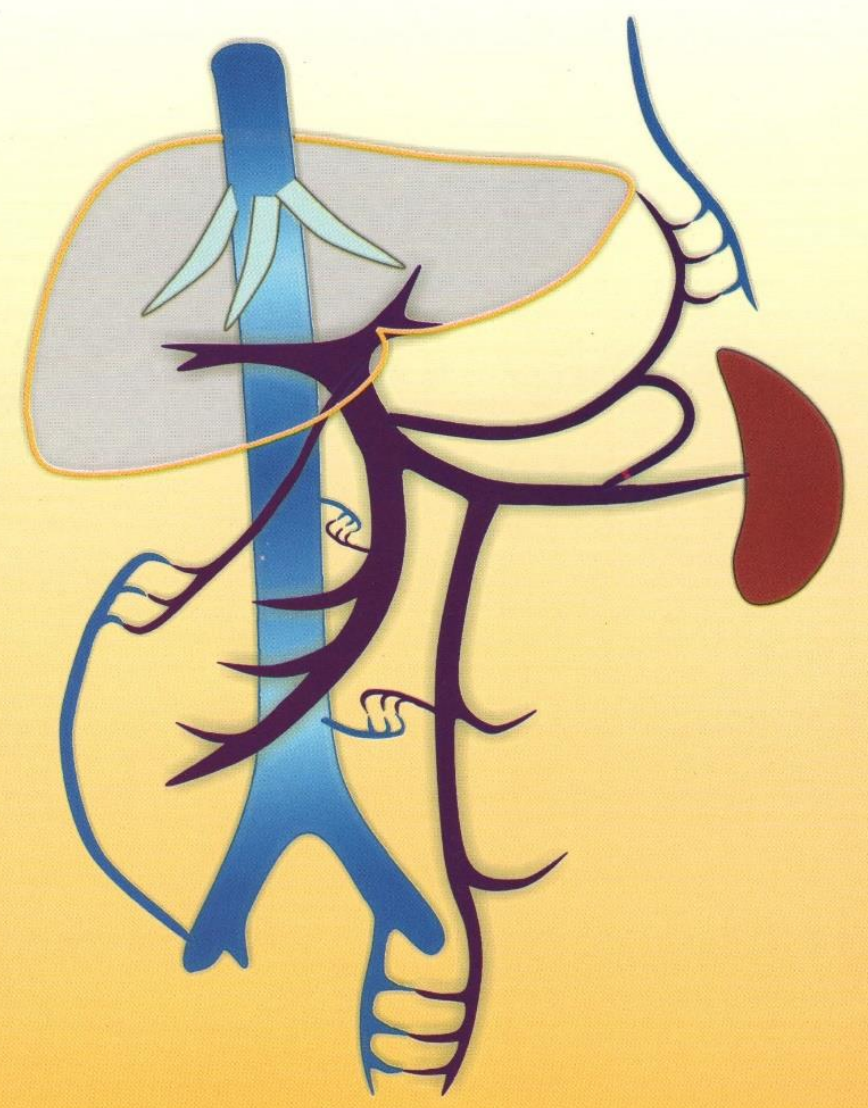

\section{BAKI-2007}




\title{
Corrahiyya Seminarlart
}

\section{PORTAL HIPERTENZIYA}

\author{
Tibb Elmlori Doktoru, Professor \\ Nuru Yusifoğlu BAYRAMOV
}

Web site www.bck.az

DOI https://doi.org/10.25045/k.nurubay.portalhiper

ISBN 9789952536096

ORCID iD https://orcid.org/0000-0001-6958-5412

\author{
BAKI 2007 \\ ISBN: 978-9952-536-09-6
}


Rəyçi: Prof. S.I.Hadıyev

Tibb Elmlari Doktoru, Professor Nuru Yusifoğlu Bayramov

Corrahiyyo Seminarlart: Portal hipertenziya

Prof. Dr. Nuru Yusifoğlu Bayramov

Cerrahi Seminerleri: Portal hipertenzion

MD, PhD, MsD, Prof.Dr. Nuru Yusifoğlu Bayramov

Seminars on Surgery: Portal Hypertension

Доктор медицинских наук, Профессор Нуру Юсифоглу Байрамов.:

Семинары по хирургии: Порталная гипертензия

\section{(C) Nuru Yusifoğlu Bayramov}

Corrahiyyə Seminarları: Portal hipertenziya. Elektron nəşr - ISBN: 978-9952-536-09-6

Cərrahiyyə və hepatologiyanın vacib mövzularından biri olan portal hipertenziyaya həsr olunan bu kitabda portal hipertenziyanın etiologiyası, patogenezi, diaqnostika və müalicəsi haqqında müasir məlumatlar yer almışdır. Portal hipertenziyanın ağırlaşmalarının, xüsusən, varikoz və qanaxma, assit, hepatorenal sindrom və hepatik ensefalopatiyanın patogenezi, diaqnostika və müalicəsi haqqında məlumatlar verilmişdir. Bu patologiyaların diaqnostik və müalicə taktikaları aydın şəkildə təqdim edilmişdir. Portal hipertenziyaya səbəb olan bir çox xəstəliklərin müalicə xüsusiyyətləri də ayrıca verilmişdir. Mövzuların asan qavranılması üçün orjinal olaraq 28 şəkil və sxem, 13 cədvəl, 47 izahlı və 31 test sualları hazırlanmışdır. Kitabda 195 yerli və xarici ədəbiyyatdan istifadə edilmişdir. Kitab tədqiqatçılar, gənc carrahlar va qastroenteroloqlar, müallimlar va talabəlar üçün nazərda tutulmuşdur. 
Type Book

Title Portal hipertenziya

\section{Editor}

Edition

Authors Bayramov Nuru Yusifoğlu

Experts Hadıyev S.

Year 10.06. 2007

Pages $\quad 138$

Abstract Cərrahiyyə və hepatologiyanın vacib mövzularından biri olan portal hipertenziyaya həsr olunan bu kitabda portal hipertenziyanın etiologiyası, patogenezi, diaqnostika və müalicəsi haqqında müasir məlumatlar yer almışdır. Portal hipertenziyanın ağırlaşmalarının, xüsusən, varikoz və qanaxma, assit, hepatorenal sindrom və hepatik ensefalopatiyanın patogenezi, diaqnostika və müalicəsi haqqında məlumatlar verilmişdir. Bu patologiyaların diaqnostik və müalicə taktikaları aydın şəkildə təqdim edilmişdir. Portal hipertenziyaya səbəb olan bir çox xəstəliklərin müalicə xüsusiyyətləri də ayrıca verilmişdir. Mövzuların asan qavranılması üçün orjinal olaraq 28 şəkil və sxem, 13 cədvəl, 47 izahlı və 31 test sualları hazırlanmışdır. Kitabda 195 yerli və xarici ədəbiyyatdan istifadə edilmişdir. Kitab tadqiqatçılar, ganc carrahlar va qastroenteroloqlar, müallimlar va talabalar üçün nazarda tutulmuşdur.

Keywords Portal, vena, hipertenziya, varikoz, assit, hepatorenal, ensefalopatiya, sarılıq, sindrom, sirroz, Baddi-Kiari, veno-okluziv, xəstəlik, tromboz, şunt, yanyol, yan-yol, porto-kaval, tromboz, 
qaraciyər, transplantasya, rezeksiya, əməliyyat, distal, proksimal, dərslik, portal hypertension

City Baku

Publisher Print- Qismet, Elektron-Azerbaycan Tibb Universiteti

Language Azerbaijani

Type of Textbook

work

URL

Web site www.bck.az

DOI https://doi.org/10.25045/k.nurubay.portalhiper

ISBN 9789952536096

ORCID iD https://orcid.org/0000-0001-6958-5412 


\section{ÖN SÖZ}

Portal hipertenziya qaraciyərin və qaraciyərdən kənar bir çox xəstəliklərin nəticəsi kimi ortaya çıxan və bir çox hallarda xəstələrin həyatını təhlükə altında qoyan ağırlaşmadır. Son illər cərrahi və terapevtik hepatologiyada bu sahədə bir çox inkişaf istiqamətləri ortaya çıxmışdır. $\mathrm{Bu}$ məlumatların ümumiləşdirilməsinə və praktik faydalı şəkildə təqdim olunmasına ölkəmizdə də böyük ehtiyac var idi. Bu baxımdan təqdim olunan kitab dəyərli sayıla bilər.

Digər tərəfdən, təqdim olunan kitab portal hipertenziyayanın etiopatogenezi, diaqnostika və müalicəsini müasir səviyyədə əks etdirən və Azərbaycan dilindəki ilk monoqrafiyadır.

Kitabda portal hipertenziyanın etiologiyasına, patogenezinə, müalicə üsulları və prinsiplərinə müasir yanaşma diqqəti cəlb edir. Xüsusən, son iki onillikdə portal hipertenziya və ağırlaşmaların müalicəsi ilə əlaqədar dünya təcrübəsində yer alan transplantasiya, endoskopik və intravaskulyar tədbirlərə kitabda geniş istinad edilmişdir. Təqdim edilən orjinal illustrasiyalar və cədvəllər təqdim olunan məlumatların asan qavranılmasina imkan verir və oxucunu yormur.

Kitabda təqdim edilən müalicə taktikaları və protokollar praktik həkimlər üçün çox faydalı vəsait hesab oluna bilər. İzahı suallar və test sualları gənc cərrahlar və tələbələrin kitabdan istifadəsinə böyük imkan yaradir.

Ümumiyyətlə, təqdim edilən kitab tədqiqatçılar, cərrahlar, hepatoloqlar və tələbələr üçün yaralı monoqrafiya, rəhbərlik və ya dərslik hesab oluna bilər.

Azorbaycan Tibb Universiteti

II corrahi xastaliklor

kafedrasinin professoru

Tibb Elmlori Doktoru, Omokdar Hokim

S.İ Hadiyev 


\section{IÇINNDӘKILӘR}

Ön söz

İçindəkilər

Qisaltmalar

Seminar 1. Portal hipertenziyanin etiologiya vo 3 patogenezi

Seminar 2. Portal hipertenziyanin

diaqnostikası və müalicəsi

Seminar 3. Sirroz 35

Seminar 4. Varikoz və Qanaxma 45

Seminar 5. Assit 71

Seminar 6. Hepatik Ensefalopatiya 81

Seminar 7. Hepatorenal sindrom 91

Seminar 8. Splenomeqaliya vo portal 99

hipertenziv qastropatiya

Seminar 9. Anadangəlmə hepatik fibroz 105

Seminar 10. Baddi-Kiari sindromu 111

Seminar 11. Veno-okluziv xəstəlik və 121

durğunluq hepatopatiyası

Seminar 12. Portal vena trombozu 127

İzahlı suallar 133

Test sualları 151

\section{TEST SUALLARININ DOĞRU CAVABLARI}

Bu cavablar test suallarının sonunda veriləcək

$\begin{array}{llllllllllllll}1 b & 2 c & 3 d & 4 b & 5 a & 6 c & 7 b & 8 a & 9 c & 10 & 11 & 12 c & 13 & 14 \\ & & & & & & & & & \text { a } & \text { b } & & \text { d } & \text { b } \\ 15 & 16 & 17 & 18 & 19 & 20 & 21 & 22 & 23 & 24 & 25 & 26 & 27 c & 28 \\ \text { c } & \text { a } & \text { d } & \text { a } & \text { b } & \text { a } & \text { c } & \text { a } & \text { d } & \text { b } & \text { b } & \text { b } & & \text { d }\end{array}$


$\begin{array}{lll}29 & 30 & 31 c\end{array}$

c $\mathbf{a}$ 
Seminar 1

\section{PORTAL HIPERTENZIYANIN ETIOLOGIYYA VO PATOGENEZI}




\section{QARACIYOR QANLANMASININ XÜSUSIYYYOTLəRİ}

Qaraciyər (Qc) orqanizmdə ən böyük parenximatoz orqan olub, humoral homeostazın təminində mərkəzi rol oynayır ki, bu da əsasən zərərli və artıq maddələrin kənarlaşdırılması (təmizləmə - detoksikasiya funksiyası) və vacib maddələrin istehsalı və tutulması (tənzimləmə - sintez, depolama və s. funksiyası) sayəsində həyata keçirilir.

Qc humoral homeostazla yanaşı hemodinamik vo sekretor funksiya da yerinə yetirir. Hemodinamik funksiya splanxik sistemdən çıxan venoz qanın ümumi qan dövranına tökülməsini təmin etməkdən və müəyyən miqdarda ( $400 \mathrm{ml})$ qanın depolanmasından ibarətdir.

Qc qan dövranı qarındaxili orqanların qan dövranı ilə sıx əlaqədardır. Ona görə də, əvvəlcə splanxik orqanların qan dövranı xüsusiyyətlərinə qısaca nəzər salmaq düzgün olardi.

\section{Həzm orqanlarının qan təhcizatı xüsusiyyətləri}

Qarındaxili həzm orqanları əsasən 5 arteriya - günəş kötüyü (ümumi qaraciyər arteriyası, sol mədə arteriyası, dalaq arteriyas1), yuxarı və aşağ 1 çöz arteriyası, sağ və sol daxili qalça arteriyaları vasitəsi ilə təhciz olunurlar. Venoz qan isə qapı venasına tökülür. Qapı venası dalaq venası və yuxarı çöz venasının birləşməsindən əmələ gəlir və Qc arteriyası ilə birlikdə qaraciyərə daxil olaraq pay, sektor, seqment və paycıq şaxələrinə ayrılır (Şəkil 1).

Qaraciyərdə arteriya və qapı venası şaxələri sinusoid adlanan kapilyarlarda birləşirlər. Sinusoidlər isə, mərkəzi venaya tökülürlər ki, bunlar da qaraciyər venalarına keçirlər. Qarındaxili həzm orqanlarının qan təhcizatının bəzi özünəməxsus xüsusiyyətləri var (Codval 1).

Birincisi, bu orqanların arteriyaları spazma və genişlənməyə çox həssasdırlar və bu xüsusiyyətinə görə yalnız dəri damarlarından geri qalırlar. Həzm vaxtı arteriyalar genişlənir ki, bu da orqanların həzm funksiyalarını (sekresiya, peristaltika, sorulma) təmini üçün vacibdir. Sirrotik xəstələrdə arteriyaların genişlənməsi və qan gəlimin artması qeyd edilir. 


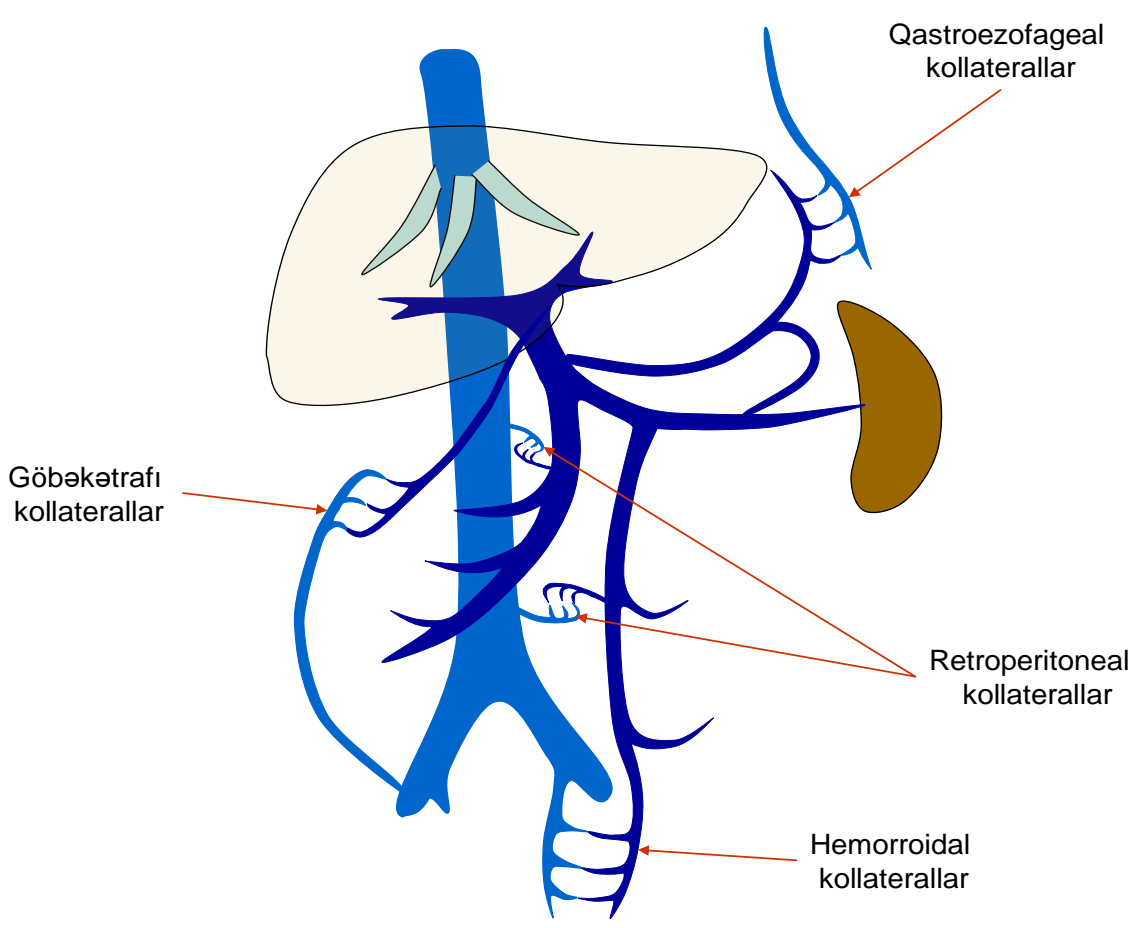

Şəkil 1. Portal qan dövranı və kollaterallar

Hipovolemik vəziyyətlərdə ilk mərhələdə qan dövranını kompensasiya etmək üçün dəri ilə bərabər splanxik damarlar yı̆̆ılaraq qangəlimini azaldırlar. Qarındaxili damarların yığılması anesteziya və laparotomiya vaxtı da meydana gəlir və qangəlimini 30-40\% azalda bilir. Belə vəziyyət uzun müddət davam edərsə (məsələn, müalicə olunmayan şok) bağırsaq və orqanlarda işemiya, hətta nekroz baş verə bilər (mədə xoraları, mədə-bağırsaq qanaxmaları, kəskin daşsız xolesistit, pankreatit, işemik hepatit və s.).

Splanxik qan dövranının ikinci xüsusiyyəti venoz qanın birbaşa ümumi venoz sistemə yox, qaraciyərə daxil olmasıdır. Bu orqanlardan çıxan venoz qan (mədə və bağırsaqlar, dalaq, mədəaltı vəzi) qapı venasında toplanaraq qaraciyərdə ikinci kapilyar tora daxil olur.

Venoz qanın ürəyə qədərki yolda ikinci dəfə kapilyara daxil olması halı yalnız qapı sistemində və nefronda mövcuddur. Qaraciyər sinusoidlərinə daxil olan qap1 venoz qanı həm zərərli maddələrdən təmizlənir, həm də əhəmiyyətli maddəlrin səviyyəsi tənzimlənir ki, bu da humoral homeostazın təmin edilməsinə şərait yaradır. 


\section{Codval 1. Splanxik orqanların qan tohcizatının xüsusiyyotlori}

\begin{tabular}{|c|c|}
\hline Xüsusiyyət & Fizioloji vo klinik əhəmiyyəti \\
\hline $\begin{array}{l}\text { Arteriyaları spazma çox } \\
\text { həssasdır }\end{array}$ & $\begin{array}{l}\text { Yemək vaxtı genişlənərək həzmi təmin edirlər } \\
\text { Dəri arteriyalarından sonra spazma ən həssas } \\
\text { sistemdir və hipovolemiyada önəmli } \\
\text { kompensator reaksiyadır. } \\
\text { Hipovolemiyada, peritona müdaxilədə } \\
\text { (laparotomiyada), anesteziyada yığılaraq } \\
\text { qangəlimini } 30-40 \% \text { azalda bilir. }\end{array}$ \\
\hline $\begin{array}{l}\text { Venoz qan ümumi sistemə } \\
\text { yox, Qc-ə gedir }\end{array}$ & $\begin{array}{l}\text { Həzm sistemi və dalaqdan gələn qanın tərkibi Qc- } \\
\text { də təmizlənir və tənzimlənir. } \\
\text { Qc xəstəlikləri vaxtı qan axını çətinləşərək portal } \\
\text { hipertenziyaya səbəb ola bilir }\end{array}$ \\
\hline $\begin{array}{l}\text { Qapı venoz sistemi ilə } \\
\text { ümumi venoz sistem } \\
\text { arasında embrional } \\
\text { kollaterallar var }\end{array}$ & $\begin{array}{l}\text { Normada yox dərəcəsində fəaliyyət göstərən } \\
\text { kollaterallar portal hipertenziyada açılaraq təzyiqi } \\
\text { kompensasiya edir. } \\
\text { Kollaterallar genişlənərək qanaxmaya səbəb ola } \\
\text { bilərlər. } \\
\text { Kollaterallar ensefalopatiyaya səbəb olurlar. }\end{array}$ \\
\hline
\end{tabular}

Qarındaxili orqanların qan dövranının üçüncü xüsusiyyəti qapı venoz sistemi ilə ümumi venoz sistem arasında kollateralların olmasıdır. Kollaterallar 4 yerdə mövcuddur: qastroezofageal, göbəkətrafi, düz bă̆ırsaqda və retroperitoneal sahədə. Qastroezofageal kollaterallar mədə və dalaq venası ilə aziqos venası arasında, göbəkatrafı kollaterallar göbək venası ilə aşağı epiqastrik vena (xarici qalça venasına) arasında, düz bağırsaq kollateralları aşağı çöz venası ilə aşağı düz bağırsaq venası və daxili qalça venası arasında, retroperitoneal kollaterallar isə dalaq venası və çöz venası ilə böyrək, böyrəküstü vəzi, bel venaları arasında əlaqə yaradırlar. Bu kollaterallar embrional mövcuddurlar və bunların normal halda fəaliyyətləri yox dərəcəsindədir. 
Kollateralların fəaliyyəti portal sistemdə və ya qarşı tərəfdə təzyiq artıqda ortaya çıxır və təzyiqi azaltmaq, venoz axını kompensasiya etmək məqsədi daşıyır.

Kollaterallar ən çox portal hipertenziyada ortaya çıxır və qapı qanını birbaşa ümumi venoz sistemə daşıyır. Bəzən ümumi sistemin bir bölgəsində təzyiq artarsa bu kollaterallar qanı portal sistemə daşıya bilirlər. Məsələn, aşağı boş vena qaraciyəraltı nahiyədə tutularsa və ya aziqos sistemində tutulma olarsa portal sistem köməkçi rol oynaya bilir. Kollateralların ikinci xüsusiyyəti genişlənmələr və qanaxma törədə bilmələridir. Qastroezofageal və göbəkətrafı venaların genişlənməsi portal hipertenizyanı göstərən əlamətlərdir. Qanaxma isə, ən çox qastroezofageal və hemorroidal varikozlardan baş verir. Göbəkətrafı varikozlar (meduza başı) zədələnmə olarsa qanaxma törədilir, retroperitoneal damarlardan qanaxma isə çox nadirdir. Kollateralların üçüncü cəhəti odur ki, portal hipertenziya nəticəsində qapı qanının bir hissəsi qaraciyərdə təmizlənmədən ümumi sistemə keçir ki, bu da toksikoza (ensefalopatiya, hepato-pulmonal sindrom və s.) səbəb olur.

\section{Qc qanlanmasının xüsusiyyətləri}

Qc qan dövranının bəzi özünəməxsus xüsusiyyətləri var (Cədvəl 2).

Birincisi, Qc ikili qan təchizatına malikdir, həm arterial həm də venoz qanla təhciz olunur. Qc-ə dəqiqədə $1 \mathrm{ml} / \mathrm{q},(\sim 1200 \mathrm{ml})$ qan gəlir ki, bu da ürək atımının 20-25\%-ni təşkil edir. Gələn qanın 1/3-ni arterial qan 2/3-sini isə splanxik orqanlardan ç1xan venoz qan təşkil edir. Bununla belə Qc-in oksigen ehtiyacının yarısı arterial qan vasitəsi ilə ödənilir. Arterial və venoz qan qaraciyərin paycıqlarında ümumi kapilyara - sinusoidlərə tökülürlər. Bir neçə sinusoid isə qaraciyər venalarının başlanğıcı hesab olunan mərkəzi venulalara açılır.

Íkinci xüsusiyyəti, qapı venası ilə Qc arteriyası arasındakı sıx funksional əlaqənin olmasıdır ki, bu da «qoruyucu arterial refleks» adlanır. Qap1 venasından gələn qan artıqda arterial qangəlimi azalır, qapı qanı azaldıqda isə, arteriyalar genişlənərək qangəlimi artırır. Bu refleksin sayəsində Qc sinusoidlərində qan axını sabit saxlanılır. Məsələn, yemək vaxtı qapı qangəlimi artdığı üçün arterial qangəlimi azalır.

Üçüncü xüsusiyyəti, qaraciyər kapilyarları sayılan sinusoidlərdə bazal membranın olmaması və divarlar endotelində böyük dəliklərin olmasıdır.

\section{Codvəl 2. Qaraciyər qan təhcizatının xüsusiyyətləri}




\begin{tabular}{|c|c|c|}
\hline Xüsusiyyat & İzah & Ohomiyyati \\
\hline İkili qan təhcizatı & $\begin{array}{l}\text { Qc arteriyas1 (qanın 1/3) }+ \\
\text { qap1 venas1 (qanın 2/3) } \rightarrow \\
\text { sinusoid } \rightarrow \text { mərkəzi vena } \rightarrow \\
\text { Qc venas1 }\end{array}$ & $\begin{array}{l}\text { Qc-in oksigen təlabatının } \\
50 \% \text { arterial, } 50 \% \text { isə, venoz } \\
\text { qanın hesabına ödənilir. } \\
\text { Splanxik sistemdən gələn } \\
\text { qan Qc-də təmizləndikdən və } \\
\text { tənzimləndikdən sonra } \\
\text { ümumi dövrana buraxılır }\end{array}$ \\
\hline $\begin{array}{l}\text { Arterial } \\
\text { qoruyucu refleks }\end{array}$ & $\begin{array}{l}\text { Qapı venasından qangəlimi } \\
\text { artarsa arterial qangəlimi } \\
\text { azalır, azaldıqda isə, artır. }\end{array}$ & $\begin{array}{l}\text { Sinusoidlərdədə qan axını } \\
\text { sabit saxlanılır }\end{array}$ \\
\hline $\begin{array}{l}\text { Sinusoid } \\
\text { endotelində } \\
\text { böyük dəliklər }\end{array}$ & $\begin{array}{l}\text { Sinusoidlərdə bazal } \\
\text { membran yoxdur və endotel } \\
\text { hüceyrələrində böyük } \\
\text { dəliklər }(50-200 \mathrm{~nm}) \\
\text { mövcuddur }\end{array}$ & $\begin{array}{l}\text { Bu dəliklər böyük } \\
\text { molekulların hepatositlərə } \\
\text { çatmasına şərait yaradır. }\end{array}$ \\
\hline $\begin{array}{l}\text { Sinusoidlərdə } \\
\text { təzyiqin aşağı } \\
\text { olması (<8 mm } \\
\text { Hg st) }\end{array}$ & $\begin{array}{l}\text { Normal halda təzyiq: } \\
\text { qapı venası: } 5-10 \mathrm{~mm} \mathrm{Hg} \mathrm{st.} \\
\text { arteriolalar: } 40 \mathrm{~mm} \mathrm{Hg} \mathrm{st.} \\
\text { sinusoidlər: }<8 \mathrm{~mm} \mathrm{Hg} \mathrm{st.} \\
\text { Qc venası: } 5 \mathrm{~mm} \mathrm{Hg} \mathrm{st.} \\
\text { Digər orqanlardak1 } \\
\text { kapilyarlarda: } 17 \mathrm{~mm} \mathrm{Hg} \mathrm{st.}\end{array}$ & $\begin{array}{l}\text { Endotelində böyük dəlikləri } \\
\text { olan sinusoidlərin } \\
\text { membransız divarından aşırı } \\
\text { transsudasiyanın qarşısı } \\
\text { alınır. }\end{array}$ \\
\hline
\end{tabular}

Təxminən 50-200 nm ölçüsündə olan bu dəliklər endotel hüceyrələrinin arasında və ya özündə yerləşirlər. Bu dəliklər böyük molekulların endotelaltı (Disse sahəsi) sahəyə keçməsinə və hepatositlərə çatmasına şərait yaradır.

Dördüncü xüsusiyyəti, sinusoidlərdə çox aşağı təzyiqin olmasıdır. Normal halda qapı venasında təzyiq 5-10 $\mathrm{mm} \mathrm{Hg}$ st., arteriolalarda $40 \mathrm{~mm} \mathrm{Hg}$ st., Qc venalarında $5 \mathrm{~mm}$ 
$\mathrm{Hg}$ st., sinusoidlərdə isə $<8 \mathrm{~mm} \mathrm{Hg}$ st. təşkil edir. Digər orqanlardakı kapilyarlarda isə, təzyiq təxminən $17 \mathrm{~mm} \mathrm{Hg}$ st. səviyyəsindədir. Sinusoidlərdə təzyiqin aşağı olması sayəsində membransız və böyük dəlikli divardan plazmanın Disse sahəsinə izafi keçməsinin qarşısı alınır.

\section{PORTAL TOZYIQQ VO HIPERTENZIYANIN MEXANIZMLORI}

Portal təzyiq dedikdə, qapı venasındakı qanın damar divarına etdiyi təzyiq nəzərdə tutulur və bu təzyiq qanın splanxik venalardan qaraciyərə və aşağı boş venaya axmasını tə'min edən əsas qüvvədir. Normal halda qapı venasında təztiq 5-10 $\mathrm{mm} \mathrm{Hg}$ st, qapı venası ila boş vena arasındakı təzyiqlar farqi $5 \mathrm{~mm} \mathrm{Hg}$ st. təşkil edir. Bu farqin 5 mm Hg st.-dan çox olması portal hipertenziya kimi qabul olunur. Tazyiqlar farqi 12 mm Hg st.-dan yüksək olduqda isə, varikoz qanaxma riski yaranır.

Hidrodinamikanın üç qanunu hemodinamikanın diğər bölgələri kimi, portal hemodinamikaya da təxmini olaraq şamil edilə bilər.

Om qanununa (1) görə damardan axan qanın miqdarı (Q) təzyiqlə (P) düz, müqavimətlə $(\mathrm{R})$ tərs mütənasibdir. Buradan, təzyiqin axan qanın miqdarı və müqavimətlə düz mütanasib olduğu görünür (2):
(1) $Q=P / R$
(2) $P=Q x R$

Pauzel qanununa (3) görə damarda müqavimət mayenin özüllülüyü (n) və damarın uzunluğu (L) ilə düz, damar radiusunun ( $r$ ) dördüncü dərəcəsi ilə tərs mütənasibdir:

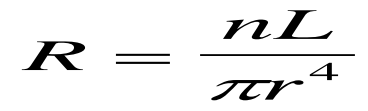

Laplas qanununa (4) görə isə, damar divarının gərilmə (G) elastiki qüvvəsi transmural təzyiq $(\mathrm{P})$ və damar radiusu ilə düz, divar qalınlığı (d) ilə tərs mütənasibdir. Yə’ni, damarın radiusu nə qədər böyük və divarı nə qədər incə olarsa, gərilmə o qədər çox olar və partlama ehtimalı da o qədər yüksəlir.

(4) $G=\frac{\operatorname{Pr}}{d}$ 
Om, Pauzel və Laplas qanunlarının portal hemodinamikaya tətbiqindən çıxan iki mühüm nəticənin birincisi tozyiqin artma mexanizmlori, ikincisi isə varikoz qanaxmanın mexanizmidir.

Birincisi, qanın özüllüyü və damar uzunluğu sabit götürülərsə, portal sistemdə təzyiq iki faktordan asılıdır: damarların radiusu va sisetma galan qanın miqdarı.

$$
P \approx K \frac{Q}{r^{4}}
$$

Düstürdan da göründüyü kimi qapı venasında təzyiqin artmasında iki amil əsas rol oynayır: müqavimətin artması vo golon qanın artması (Şəkil 2). Mütənasiblik radiusun dördüncü dərəcəsinə uygun oldğu üçün radiusun azacıq kiçilməsi müqavimət və təzyiqin böyük dərəcədə artmasına səbəb olur. Qeyd etmək lazımdır ki, bu iki mexanizmdən biri təkbaşına ilkin mərhələdə əsas rol oynayır. Hipertenziya inkişaf etdikcə prosesə ikinci mexanizm də qoşulur .

Hemodinamik qanunların portal hemodinamikaya tətbiqindən ortaya çıxan ikinci nəticə isə, varikoz qanaxmanın mexanizmidir. Varikoz qanaxma genişlənmiş damarların nazilmiş divarlarında baş verən gərilmə və cırılma nəticəsində meydana gəlir. Laplas qanununa görə təzyiqin artması, radiusun artması və divarın qalınlığının azalması ilə gərilmə qüvvəsi də artır. Ona görə də, portal təzyiqin artması ilk növbədə böyük və nazik divarlı (III və IV dərəcə) varislərdən qanaxmaya səbəb olur. Bu səbəblə əlaqədar varikoz qanaxmanın profilaktikasında təzyiqin azaldılması ilə yanaşı varislərin kiçildilməsi (liqasya, skleroterapiya) də əhəmiyyətlidir.

\section{PORTAL HIPERTENZIYANIN SӘBӘBLӘRI}

\section{Müqavimətin artması}

Qan damarlarının mənfəzinin daralması (fibroz, s1xılma), tıxanmas1 (tromboz) və ya sayca azalması (rezeksiya, sirroz, nekroz) axına müqavimətin artmasına səbəb olur (Cədval 3). Qapı qanının axın yoluna nəzər salsaq görünür ki, qan qapı sistemindən, qaraciyərdaxili damarlardan, qaraciyər venaları və aşağı boş venadan keçir. 


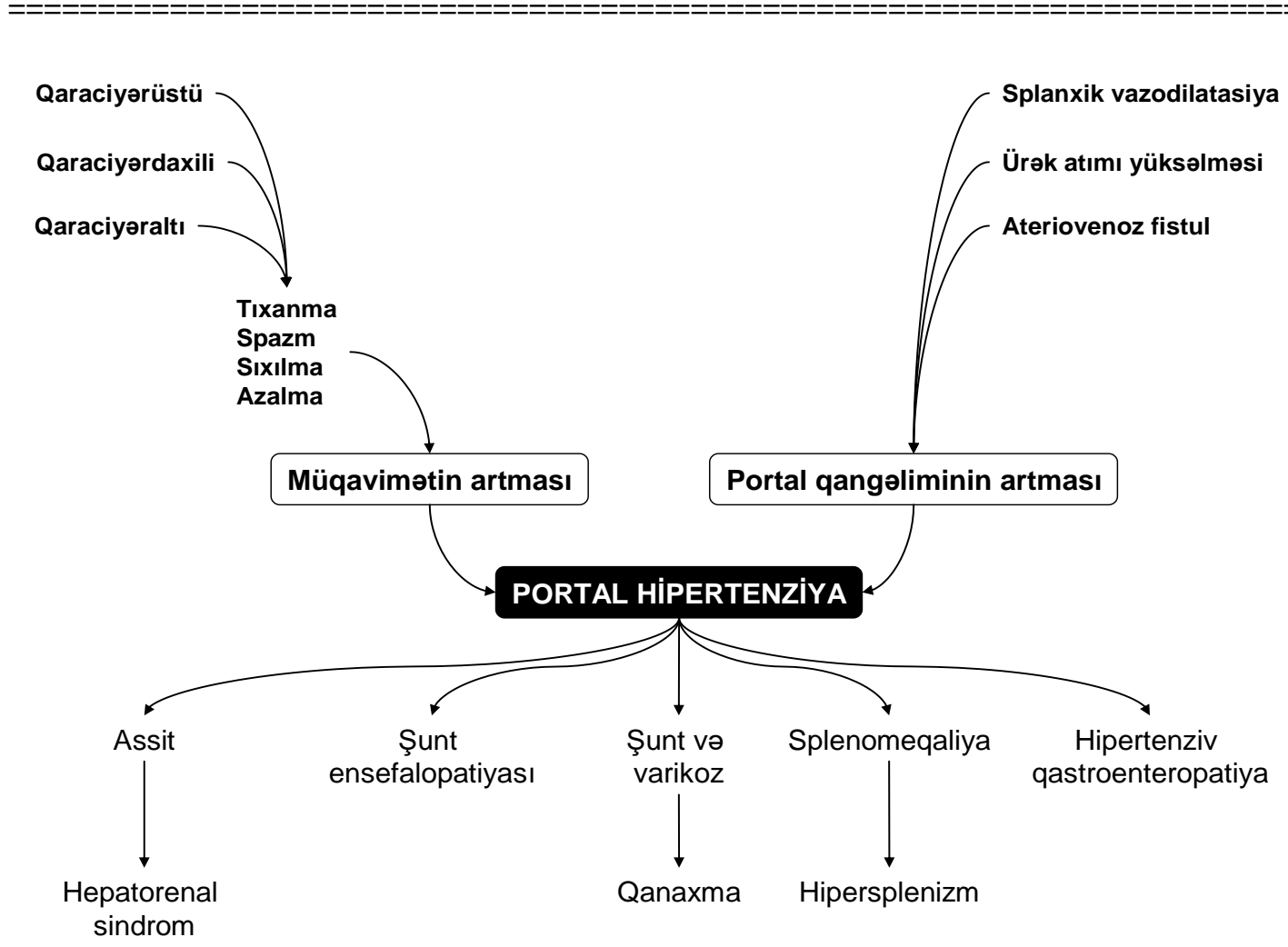

\section{Şəkil 2. PH-ın patogenezi və patofiziologiyası}

$\mathrm{Bu}$ anatomik bölgüyə əsaslanaraq portal qan axınına əngəl olan (radiusu kiçildən) amilləri üç qrupa bölmək olar: qaraciyəraltı, qaraciyərdaxili və qaraciyərüstü.

Qaraciyaraltı amillar

$\mathrm{Bu}$ qrupdan olan patologiyalar qap1 venasını kənardan sıxaraq və ya mənfəzini tutaraq venoz axını əngəlləyirlər. Portal venanın trombozu, venaətrafı şişlər (qapı, mədə, MAV, öd kisəsi, xoledox şişləri, limfomalar), ən çox rast gələn amillərdir. Portal tromboz hiperkoaqulyasiya vəziyyətlərində (Protein C, S defisiti, Leyden mutasiyas1, Lupus antikoaqulyantı və s.), şişlərin nəticəsində, iltihabi xəstəliklərdə (xronik pankreatit, peritonit və s.), bəzən də anadangəlmə (portal vena kavernoz transformasiyas1) ola bilər. Qapı sistemində tromboz bölgəsəl (dalaq venası, çöz venası trombozu) və ya total (qap1 venası trombozu) şəkildə ortaya çıxa bilir. 
Codval 3. Portal hipertenziyanm səbəbləri

\section{Müqaviməti artıran səbəblor}

Qaraciyəralt1

Portal tromboz

Portal kavernoz transformasiya

Dalaq venası trombozu

Portal vena sıxılması (şiş, düyün,

xr.pankreatit və s)

Qcaraciyərdaxili

Sinusalt1

Şistostoma

Sarkoidoz

Mielofibroz

Anadangəlmə hepatik fibroz

Hepatoportal fibroz

Hepatotoksinlər (arsen, azatioprin, vinilxlorid və s)

Erkən biliar sirroz

Erkən skleroz xolangit

Sinusoidal

Sirroz

Metotraksat

Alkoqol hepatiti

Hipervitaminoz A

Nodulyar regenerativ

hiperplaziya

Sinusüstü

Venokluziv xəstəliklər

Baddi-Kiari sindromu

Qaraciyərüstü

ABV membranı

Zirehli perikardit

Sağ ürək yetməzliyi

\section{Portal hocmi arturan saboblor}

Arterio-venoz fistul

Sirroz (portal arterializasiya)

Splenomeqaliya
Qaraciyardaxili amillar

$\mathrm{Bu}$ amillər portal hipertenziyanın ən çox rast gələn səbəbləridir $(80 \%)$. Praktik olaraq qaraciyərdə diffuz iltihab və fibroz törədən bütün xəstəliklər portal hipertenziyaya səbəb ola bilərlər. Qaraciyərdaxili amillər qaraciyər daxilində müxtəlif səviyyədə qan axınını əngəlləyərək hipertenziya törədirlər. Bəzən bir xəstəlik qaraciyərdə bir neçə səviyyədə əngəlləmə törədə bilirlər. $\mathrm{Bu}$ xəstəlikləri ən çox əngəllədikləri bölgəyə əsaslanaraq üç qrupa bölmək olar: sinusönü, sinus və sinusüstü.

Sinusönü səbəblər qap1 venasının böyük və kiçik şaxələrində əngəlləmə törədirlər. $\mathrm{Bu}$ səbəblər arasında qaraciyərdaxili venoz tromboz, sarkoidoz, şistomatoz, anadangəlmə portal fibroz, birincili biliar sirroz və skleroz xolangit əsas yer tutur. $\mathrm{Bu}$ xəstəliklər əsasən portal damarlar ətrafinda fibroz törədərək qapı şaxələrini s1xırlar.

Sinusoidal səviyyədə əngəlləmə törədən səbəblər arasında virus və alkoqol sirrozu əsas yer tutur. 


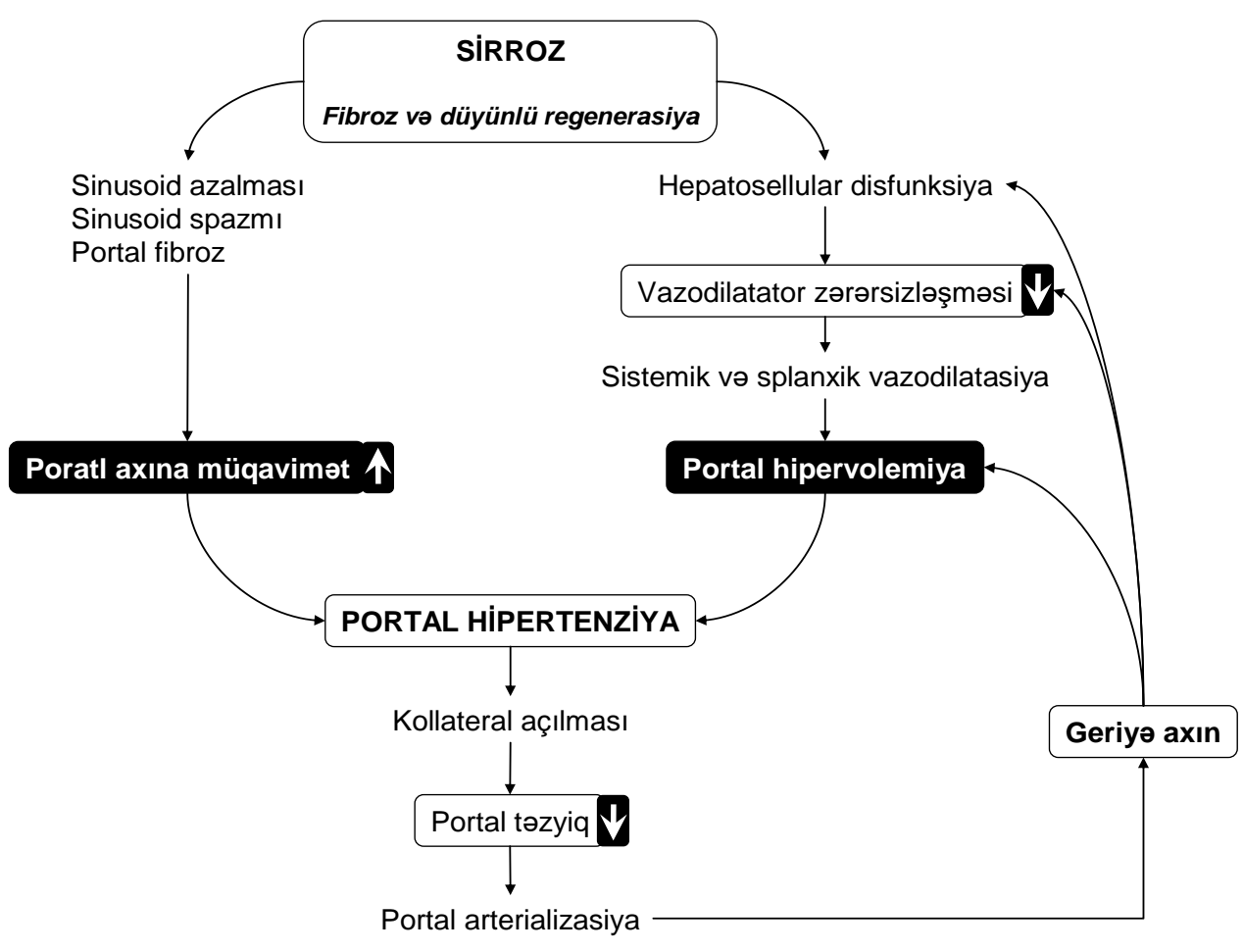

Şəkil 3. Sirroz və PH-da qüsurlu dövran

Ümumiyyətlə sirroz portal hipertenziyanın ən çox rast gələn səbəbidir və sirrotik xəstələrin təxminən 60-70\%-ində portal hipertenziya meydana ç1xır. Sirrozun portal hipertenziya törətməsində üç əsas mexanizm rol oynayır: sinusoidlərin üzvü azalması, sinusoidlarin funksional spazmı va portal qangəlimin artması. Sirroza xas olan iki əsas proses - fibroz və düyünlü transfomasiya sinusoidlərin miqdarca azalmasına gətirib çıxarır. Çünki, fibroz itirilmiş normal qaraciyər parenximasının yerində inkişaf edən «sinusoidsiz» birləşdirici toxumadır və düyünlü transfomasiyalı qaraciyər toxumasında damar arxitektorikası pozulmuş vəziyyətdə olur. Normal halda sinusoidlərdəki endotellə hepatositlər arasındakı sahədə (Disse sahəsi) ulduzvari Lito hüceyrələri (lipositlər də deyilir) mövcuddur. Lito hüceyrələri sinusoidlərin yığılmasında və zədələnmə vaxtı fibrogenezdə əsas rol oynayırlar. Hesab editlir ki, sirrozda Lito hüceyrələri artaraq mioepitelial (yı̆̆glma qabiliyyəti olan çapıq toxuma hüceyrələri) xarakterli hüceyrələrə çevrilirlər və həssaslıqları dəyişir. Hepatosellular və epitelial disfunksiya yerli vazoaktiv maddələrin (nitrik oksid, endotelin, prostoqlandinlər) balansının vazokonstruktorlar xeyrinə dəyişməsinə şərait yaradır. $\mathrm{Bu}$ iki amil - spazma həssaslığın artması və vazokonstruktorların üstünlüyü sinusoidlərdə 
spazmı artırır. Digər tərəfdən sirrozda ümumi hormonal balansın pozulması isə portal sistemə qan gəlməsini artırır (aşağıya bax).

Sinusüstü səbəblər qaraciyər venalarında qan axınını əngəlləyərək portal hipertenziyaya səbəb olurlar. Bunlara venokluziv xəstəliklər və hepatik vena trombozu (Baddi-Kiari sindromu) aiddir.

\section{Qaraciyərüstü sabablar}

Qaraciyərüstü mexanizmlər aşağı boş vena səviyyəsində qan axınını çətinləşdirərək portal hipertenziyaya səbəb olurlar. Aşağı boş venada membran, tromb, zirehli perikardit, sağ ürək yetməzliyi bunlara aiddir.

\section{Portal hipervolemiya}

Portal hipervolemiya, yəni qap1 sisteminə daxil olan qanın həcminin artması portal hipertenziyanı törədən ikinci önəmli mexanizmdir. Bu mexanizmin əsasında iki proses dura bilər: splanxik sistemə gələn arterial qanın artması, birbaşa olaraq qapı venasına daxil olan qanın artmast.

Splanxik arterial qanın artması ya arterial vazodilatasiya, ya da splenomeqaliya nəticəsində baş verir. Birincili splenomeqaliyalar (tropikal splenomeqaliya, neoplastik splenomeqaliya və s.) vaxtı orqana gələn qan artır ki, bu da çıxan venoz qanın artmasına və beləliklə də qapı venasının yükünün artmasına səbəb olur. Splanxik arterial vazodilatasiya adətən sirrozun nəticəsində ortaya çıxır. Bunun vazoaktiv hormonal disbalansa bağlı olduğu hesab edilir. Güman edilir ki, sirrozda orqanizmdə, o cümlədən splanxik sistemdə vazodilatator humoral maddələr artır. Bu bir tərəfdən ürək atımını artıraraq, digər tərəfdən isə splanxik arterial müqaviməti azaldaraq daxili orqanlara qangəlimi yüksəldir. Sirrotik xəstələrdə hiperdinamik vəziyyət (ürək fəaliyyətinin artması, vazodilatasiya) isbat olunmuş fakt olsa da, mexanizmi, xüsusən hormonal disbalansın mexanizmi dəqiqləşməmişdir. Vazodilatator humoral maddələrin (qlukaqon, prostoqlandin, NO, adenozin, öd turşuları, substansiya P, TNF və s.) artması haqqında iki nəzəriyyə var. Birincisinə görə, sirrozda hepatosellular 
disfunksiyaya və kollaterallara bağlı olaraq normal miqdardakı maddələr zərərsizləşdirilmədən ümumi dövrana daxil olur. İkinci nəzəriyyəyə görə sirrozda bu maddələrin splanxik sistemdə sintezi artır. Qeyd etmək lazımdır ki, hazırda portal hipertenziyanı azaltmaq üçün istifadə edilən dərmanlar ( $\beta$-adrenoblokatorlar, somatostatin) məhz splanxik vazokonstruksiya törətmək məqsədi ilə tətbiq edilir. $\beta$ blokatorlar ürək fəaliyyətini azaldır və splanxik arterial vazokonstruksiya törədirlər, somatostatin (və ya sintetik analoqu oktreotid) isə əksər qastrointestinal hormonların (o cümlədən vazodilatatorlar olan qlukaqonun, vazoaktiv intestinal pepdidin, substansiya P-nin və s.) sintezini əngəlləyərək vazospazma səbəb olur.

Portal qanın birbaşa artması, başqa sözlə portal arterializasiya da adlanır. Belə halda arterial qan birbaşa portal sistemə keçir. Bunun iki klassik variantı - birincili və ikincili variantları var. Birincili varianta anadangəlmə (nadir hallarda zədələnmə nəticəsində) arterio-venoz fistullar belə hal törədirlər. İkincili variant sirrozda rast gəlir və portosistemik paradoks adlanır. Sirrozda genişlənən porto-sistemik kollaterallar portal hipertenziyanı azaldır. Kollaterallarda müqavimət Qc-ə nəzərən çox az olduğu üçün portal qanın əksər hissəsi (bəzən 90\%) kollaterallardan gedə bilir. Bunun nəticəsində qaraciyərə daxil olan qapı qanı və qaraciyərdaxili portal təzyiq ciddi azalır. Nəticədə qaraciyərin arterial və sinusoidal qanı portal sistemə keçərək «geriyə», kollaterallara doğru hərəkət edir. Dopler müayinələrində belə hal qapı venasında qanın «geriyə» (retroqrad və ya hepatofuqal axın) axını kimi görünür. Geriyə axın Qc-ın qan təhcizatını ciddi pozmaqla yanaşı portal qanın arterial qan hesabına artmasına səbəb olur. Beləliklə, sirroz portal hipertenziyanı həm törədir, həm də dəstəkləyir. Başqa sözlə, sirrozda portal hipertenziya qüsurlu dövranı yaranır. Sirroz həm portal axına müqaviməti üzvü (sinusoid zədələnməsi, fibroz) və funksional yolla (sinusoid spazmı) artıraraq, həm də portal hipervolemiya törədərək (splanxik arterial dilatasiya, portosistemik paradoks - portal arterializasiya) portal təyiqi artırır və davam etməsinə səbəb olur.

POPRTAL HİPERTENZIYYNIN PATOFIZİLLOGIYYASI Və TəBİ GEDİŞI 
Qeyd edildiyi kimi, PH birincili xəstəlik olmayıb, digər xəstəliklərin ağırlaşması kimi meydana gələn sindromdur. Lakin, PH-nın özü də digər patologiyalara səbəb olur. Portal venalarda təzyiqin artması nəticəsində aşağıdakı patologiyalar meydana çıxır

(Şəkil 2):

- assit

- varikoz və qanaxma

- ensefalopatiya

- splenomeqaliya

- hepatorenal sindrom

- porto-hipertenziv qastro-enteropatiya

$\mathrm{Bu}$ patologiyalar haqqında sonrakı bölümlərdə geniş məlumat veriləcəkdir. Qeyd etmək lazımdır ki, PH ardan qalxdıqda bu patologiyalar da geriyə inkişaf edə bilir. Digər tərəfdən bu patologiyaların ağırlıq dərəcəsinə təsir göstərən önəmli amil Qc-in funksional vəziyyətidir. Hepatosellular funksiya saxlanılan hallarda (məs. qaraciyəraltı $\mathrm{PH}$, anadangəlmə hepatic fibroz) ensefalopatiya və assit dərinləşmir. Hepatosellular funksiya pozulan xəstələrdə (məs. sirroz) bu agırlaşmalar nəinki dərinləşir, həm də yeni paologiyalar (hepato-renal sindrom, hepato-pulmonal sindrom, hormonal disfunksiya və s.) meydana çıxır.

\section{Osas ədəbiyyat}

1. Ağayev B.A. Corrahi Xəstวliklar. Bakı 2001

2. Blumgart LH. Surgery of the Liver, Biliary tract and Pancreas. 4th ed. 2006

3. Cuschieri SA. Disorders of the liver. Module 10, p 321-374. in Cuschieri SA, Steel RJ, Moossa AR. Essentiale Surgical practice.. $4^{\text {th }}$ ed. 2002

4. Feldman M, Friedman LS, Sleisenger MH. Sleisenger and Fordtran's Gastrointestinal and Liver diseases. $7^{\text {th }}$ ed. Vol II, 2002.

5. Modern Surgical Care. 2 ed. Vol I, 1998

6. Oxford textbook of Surgery V.1, 2004

7. Rob and Smith's Hepatobiliary and Pancreatic Surgery. 2. ed. 1996

8. Sabiston. Textbook of Surgery 17 ed., 2006, p.1112-1143

9. Timothy DS, Steven AC. Liver. Chapter 30, p 1139-1186. in Schwartz"s Principles of Surgeryl8th ed., 2004

10. Thomas JN, Gordon AH. Pathophysology. International edition. 3th ed. P 369396, 2004

11. Sherlock S, Dooley J. Disease of the liver and biliary tract. 11-th ed. 2001 
12. Sultanov H.A. Carrahi Xastaliklar. Bakı 2000

13. Surgical Anatomy and Embriology. Surgical Clinics of North America Vol 73, no 4, 1993

14. William RJ. Liver and Portal venouse system. In: Gerard MD, Lawrence WW, Current Surgical Diagnosis and Treatment. $12^{\text {th }}$ edition, 2006, p 539572

15. Zudema GD. Shackelford's Surgery of Alimentary tract, Vol III, 5th ed, 2006

\section{Olavo adobiyyat}

1. Deltenre P, Mathurin P, Barraud H, Bronowicki JP, Jacquet E, Puche P, Jaber S, Navarro F, Pageaux GP. Managing the complications of cirrhosis. Rev Prat. 2005 Sep 30;55(14):1555-63.

2. Debray D, Yousef N, Durand P. New management options for end-stage chronic liver disease and acute liver failure: potential for pediatric patients. Paediatr Drugs. 2006;8(1):1-13.

3. Dib N, Konate A, Oberti F, Cales P. Non-invasive diagnosis of portal hypertension in cirrhosis. Application to the primary prevention of varices. Gastroenterol Clin Biol. 2005 Oct;29(10):975-87.

4. De Palma GD, Rega M, Masone S, Persico F, Siciliano S, Patrone F, Matantuono L, Persico G. Mucosal abnormalities of the small bowel in patients with cirrhosis and portal hypertension: a capsule endoscopy study. Gastrointest Endosc. 2005 Oct;62(4):529-34

5. De Gottardi A, Dufour JF. Oesophageal and fundic variceal bleeding. Ther Umsch. 2006 May;63(5):295-9.

6. Garcia-Tsao G. Portal hypertension. Curr Opin Gastroenterol. 2006 May;22(3):254-62

7. Han MK, Hyzy R. Advances in critical care management of hepatic failure and insufficiency. Crit Care Med. 2006 Sep;34(9 Suppl):S225-31

8. Hou MC. Developments in the treatment of acute esophageal variceal bleeding. J Chin Med Assoc. 2006 Feb;69(2):55-7.

9. Iversen P, Hansen DA, Bender D, Rodell A, Munk OL, Cumming P, Keiding S. Portal hypertension. Curr Opin Gastroenterol. 2006 May;22(3):254-62.

10. Karajeh MA, Hurlstone DP, Stephenson TJ, Ray-Chaudhuri D, Gleeson DC. Refractory bleeding from portal hypertensive gastropathy: a further novel role for thalidomide therapy? Eur J Gastroenterol Hepatol. 2006 May;18(5):545-8.

11. Laleman W, Landeghem L, Wilmer A, Fevery J, Nevens F. Portal hypertension: from pathophysiology to clinical practice. Liver Int. 2005 Dec;25(6):1079-90.

12. Liu QD, Zhou NX, Zhang WZ, Wang MQ. Diagnosis and management of regional portal hypertension. Chin J Dig Dis. 2005;6(2):87-92.

13. Liu H, Gaskari SA, Lee SS. Cardiac and vascular changes in cirrhosis: pathogenic mechanisms. World J Gastroenterol. 2006 Feb 14;12(6):837-42. 
14. Laleman W, Landeghem L, Wilmer A, Fevery J, Nevens F. Portal hypertension: from pathophysiology to clinical practice. Liver Int. 2005 Dec;25(6):1079-90.

15. Petroianu A, De Oliveira AE, Alberti LR. Hypersplenism in schistosomatic portal hypertension. Arch Med Res. 2005 Sep-Oct;36(5):496-501.

16. Paramesh AS, Meiners R, Fairchild RB, Sane S, George M, Van ThielDH. Retroperitoneal varices presenting as an adrenal pseudotumor in a cirrhotic patient.WMJ. 2006 Jun;105(4):44-6.

17. Rana SS, Bhasin DK, Jahagirdar S, Raja K, Nada R, Kochhar R, Joshi K. Is there ileopathy in portal hypertension? J Gastroenterol Hepatol. 2006 Feb;21(2):392-7.

18. Sandhu BS, Sanyal AJ. Management of ascites in cirrhosis. Clin Liver Dis. 2005 Nov;9(4):715-32.

19. Superina RA, Alonso EM. Medical and Surgical Management of Portal Hypertension in Children. Curr Treat Options Gastroenterol. 2006 Sep;9(5):432-443.

20. Svensson M, Wiren M, Kimby E, Hagglund H. Portal vein thrombosis is a common complication following splenectomy in patients with malignant haematological diseases. Eur J Haematol. 2006 Sep;77(3):203-9. 
Seminar 2

\section{PORTAL HIPERTENZIYANIN DİAQNOSTÍKASI Və MÜALÍCəSİ}




\section{PORTAL HİPERTENZIYYANIN DİAQNOSTIKASI}

PH-nın əlamətlərini iki qrupa bölmək olar: dolayı (şübhə) və birbaşa (dəqiqləşdirici). Xronik qaraciyər xəstəliyi əlamətləri (teleangioektaziya, palmar eritema, hepatomeqaliya, palpator sərt qaraciyər), assit, mədə-bağırsaq qanaxması və splenomeqaliya PH-a şübhə yaradan göstəricilərdir.

PH-1 təsdiqləyən əlamət varikoz genişlənmə və portal təzyiqin artmasıdır. Göbəkətrafı varikozlar adi müayinə ilə, qida borusu varikozları endoskopik müayinə ilə, portal vena genişlənməsi Dopler USM, KT və ya MR-angioqrafiya ilə müəyyən edilir.

PH-ın ikinci xarakterik əlaməti sayılan təzyiq artmasını təyin etməyə həmişə ehtiyac qalmır. Lakin bəzi hallarda, xüsusən PH-1 inkar etmək və ya səbəbini təyin etmək üçün təzyiq ölçməyə gərək qalır. Təzyiqi ölçmək üçün iki yol mövcuddur - birbaşa və dolayı. Birbaşa üsulda portal venaya müdaxilə edilərək təzyiq ölçülür. Bu üsul hazırda geniş istifadə olunmur, yalnız əməliyyat vaxtı tətbiq edilir. Dolayı üsul qapı venası ilə aşağı boş vena arasındakı təzyiqlər fərqini təyin etməyə əsaslanır.

\section{PH-ın səbəb və yerinin təyini}

Porto-kavaqrafiya və təzyiq ölçülməsi əksər hallarda PH-ın səviyyəsini və səbəbini təyin etməyə imkan verir. Hazırkı qeyri-invaziv üsullar (Dopler USM, KTangioqrafiya, MR-angioqrafiya) da portal axına maneənin yerini təyin edə bilir. Nadir hallarda adi kontrastlı angioqrafiyaya ehtiyac yaranır.

Tazyiq ölçülməsi PH-ın olub-olmadığını və yerini təyin etməyə imkan verən bir üsuldur. Oslində PH-ın təyini üçün bu yol daha məntiqlidir və texniki cəhətdən ağciyər arteriyalarında üç təzyiqin ölçülməsinə yaxındır. Vidaci venadan keçərək aşağı boş venaya və Qc venasına təzyiq ölçən ucluq yerləşdirilir. Әvvəlcə ucluq Qc venasına ən son nöqtəyə qədər yerləşdirilir və bu səviyyədə təzyiq ölçülür. Buna Qc venası uc təzyiqi (QcVUT) deyilir. Hesab edilir ki, uc təzyiq sinusoiddəki təzyiqə bərabərdir vo bu portal venadakı təzyiqə yaxındır. Sonra təzyiq ölçən geri çəkilərək aşağı boş vena səviyyəsində sərbəst təzyiq ölçülür ki, buna aşağı boş vena təzyiqi (ABVT) deyilir. Sonra bu iki təzyiq arasındakı fərq hesablanır və bu porto-kaval qradiyent (PKQ) qəbul olunur. Bu qradiyent normal halda 3-5 mm Hg st. təşkil edir.

\section{Cədvəl 1. Porto-kaval təzyiqlərin ölçülməsinə görə kliniq qiymətləndirmə}




\begin{tabular}{|c|c|c|c|}
\hline PH-n növï & QcVUT & ABVT & PKQ \\
\hline Qaraciyəraltı & Normal & Normal & Normal \\
\hline Presinusoidal & Normal & Normal & Normal \\
\hline Sinusoidal & Yüksək & Normal & Yüksək \\
\hline Postsinusoidal & Yüksək & Normal & Yüksok \\
\hline Qaraciyərüstü & Yüksək & Yüksək & Normal \\
\hline
\end{tabular}

Qradiyentin 5 mm Hg st. çox olması PH-1 göstərir. Qeyd etmək lazımdır ki, bu üsulla təzyiq fərqinin hesablanması həmişə doğru nəticə verməyə bilər. Xüsusən xəstədə qaraciyəraltı və presinusoidal PH olarsa təzyiqlər fərqi normal ola bilər. Lakin PKQin təyini bir çox hallarda faydalı olur və $\mathrm{PH}-1 n$ səviyyəsini təiyn etməyə imkan verir. Ölçülən göstəricilərə (üç təzyiq, boş vena təzyiqi və təzyiqlər fərqi) əsaslanaraq portal axına maneənin səviyyəsini müəyyənləşdirmək olur (Codvəl 1 ). Qeyd etmək lazımdır ki, təzyiqin ölçülməsi əsasında qaraciyərdaxili PH-lar üç qrupa ayrılır: presinusoidal, sinusoidal, postsinusoidal.

Qaracyiaraltı və presinusoidal PH-larda qapı təzyiqi yüksək olsa da, hər üç göstərici normal olur. Yəni bu halda üc təzyiq portal təzyiqi aks etdirmir. ABVT-nin normal, qradiyentin yüksək olması sinusoidal və postsinusoidal PH-larda olur. Hər iki təzyiqin yüksək, PKQ isə normal olması qaraciyərüstü PH-1 göstərir.

Oksər hallarda aparılan klinik, laborator və görüntüləmə üsulları ilə PH olub-olmadığı və yeri ilə yanaşı nozoloji səbəbi də təyin oluna bilir. Səbəb axtarışında önəmli yolgöstərən amil PH-1n səviyyəsidir. Qaraciyəraltı PH-da ilk növbədə portal tromboz və şişlər araşdırılır. Qaraciyərüstü formada isə, ürək yetməzliyi və Baddi-Kiari sindromu ön planda tutulur. Qaraciyər səviyyəsindəki PH-da ilk növbədə Qc sirrozu araşdırılmalıdır. Bunun üçün də, biopsiya vacib şərtdir.

\section{Diqnostik alqoritm}

Beləliklə, ümumi diaqnostik alqoritmə uygun olaraq (şübhə, dəqiqləşmə, forma və səbəb təyini) PH diaqnostikasında aşağıdakı ardıcllığı tövsiyə etmək olar:

- Şübhəli xəstələrdə (assit, splenomeqaliya, hepatomeqaliya, mədə-bağırsaq qanaxması, xroniki qaraciyər əlamətləri və s.) PH-1n olub-olmadığını 
müəyyənləşdirmək üçün dəqiqləşdirici əlamətlər (damar genişlənməsi və təzyiq artmas1) axtarılır. Klinik, Doler USM, KT/MRT angioqrafiyalarda, endoskopik müayinələrdə damar genişlənməsinin görünməsi diaqnozu təsdiqləyir, görünməməsi isə, şübhəni ciddi şəkildə azaldır.

- Oksər hallarda klinik və görüntüləmə müayinələri PH-ın yeri və səbəbini təyin etməyə imkan verir. Diaqnostik çətinliklərdə təzyiq ölçülməsinə ehtiyac yarana bilər.

- PH-1 olan bütün xəstələrdə Qc-in funksional (QcFT) və morfoloji (Qc biosiyası) vəziyyətini, qaraciyərüstü $\mathrm{PH}-\mathrm{da}$ isə bununla yanaşı ürəyin funksional vəziyyətini (EKO) dəqiqləşdirmək vacibdir.

\section{PORTAL HIPPERTENZIYYANIN MÜALİCOSI}

PH-ın müalicəsi üçün müxtəlif dövrlərdə çoxsaylı üsullar və strategiyalar təlif edilmişdir. Hazırkı dövrdə PH-n müalicəsində ən çox tövsiyə olunan strategiya aşağıdakından ibarətdir.

PH-nın müalicəsində ilk vo asas hədəf səbəbin aradan qaldırılmasıdır. Məsələn sirrozda Qc transplantasiyası, birincili splenomeqaliyada splenektomiya, arterio-portal fistulda fistulektomiya və s. Səbəbin aradn qaldırılması nəinki PH-1 azaldır, həm də ağırlaşmaların və nəticələrin geriyə inkişafına şərait yaradır.

Hər hansı səbəbdən birinci hədəfə çatmaq mümkün olmadıqda ikinci hədəf seçilir ă̆ırlaşmaların müalicəsi. PH-ın ağırlaşmalarının müalicəsi aşağıdakı qaydalarla həyata keçirilir:

- Ağırlaşmalar baş verdikdə və ya risqi yüksək olduqda müalicə tələb edir

- Ağırlaşmaların müalicəsi əsasən iki yolla həyata keçirilir: Qc qanlanmasını pozmadan portal təzyiqi azaltmaq vo ă̆ırlaşmaya spesifik birbaşa tədbirlor.

- Ağırlaşma yoxdursa və ya risqi yüksək deyilsə profilaktik olaraq PH-1 azaltmağa ehtiyac yoxdur. 
Qeid etmok lazımdır ki, bu umumi yanaşmanın birinci hədəfi bütün xəstələr üçün keçərlidir, ikinci hədəf isə, xəstələrin əksəriyyətinə, o cümlədən də, sirrozlu xəstələrə şamil edilir. $\mathrm{Bu} \quad$ strategiyadan kənaraçıxmalar barəsində uyğun bölümlərdə məlumat veriləcəkdir.

\section{Portal təzyiqi azaltma prinsipləri} və tədbirləri

PH-nın baş verməsində müqavimət artmasinin və portal hipervolemiyasının əsas patogenetik amillər oldğunu nəzərə alaraq təzyiqi azaltmaq tədbirləri də iki prinsip üzərində qurulur: müqaviməti və portal sistemo qan golimini azaltmaq (Cadval 2). Bunlara medikamentoz, carrahi va endovaskulyar tadbirlari aid etmək olar.

\section{Medikamentoz tədbirlər}

Portal sistemdə təzyiqi azaltmaq üçün müxtəlif təbiətli dərmanlar istifadə olunur. Bunlardan bəziləri geniş klinik tətbiq tapmış, digərləri isə sınaq dövrünü yaşayır.

\section{Cadval 2. Portal hipertenziyanm} müalicə prinsipləri vo tədbirləri

\section{Səbəbi ardan qaldırma}

Qc transplantasiyas1

Portal trombektomiya

Splenektomiya

Membranektomiya

Kardio-korreksiya

Arterio-venoz fistulun ləğvi

Digər

\section{Portal tozyiqi azaltma}

Müqaviməti azaltma

$$
\begin{aligned}
& \text { Portokaval yanyol } \\
& \text { (dekompressiya) } \\
& \text { Qc-daxili vazodilatasiya (NO } \\
& \text { sələfləri)? } \\
& \text { Kollateral vazodilatasiya (NO } \\
& \text { sələfləri)? }
\end{aligned}
$$

Portal qangəlimi azaltma

Splanxik vazokonstruktorlar Somatostatin (oktreotid) Vazopressin (glipressin) $\beta$-adrenoblokatorlar

\section{Diuretiklər}

Splenektomiya

Hissəvi dalaq embolizasiyası

Dalaq arteriyası stendlənməsi

\section{A ğırlaşmaların müalicəsi}

Endoskopik liqasiya

Endoskopik skleroterapiya

Zondla tamponada

Diuretik

Laktuloza, laktibiol

Ornitin-asetat

Devaskulyarizasiya 
Somatostatin mədəaltı vəzin D hüceyrələrindən ifraz olunan hormon olub, orqanizmdə, xüsusən də mədə-bağırsaq sistemində həm hormonların sintezini, həm də sekresiyanı ciddi azaldır. Bu hormon splanxik qangəlimini də ciddi azaldır. Hesab edilir ki, somatostatin yerli vazodilatator sintezini azaldaraq splanxik vazodilatasiyanı əngəlləyir. Somatostatinin ən çox istifadə edilən dozası $250 \mathrm{mkq}$ ilk doza və sonra 250-500 mkq/saat infuziya. Dərman 5-7 gün istifadə edilə bilər. Somatostatin ən çox varikoz qanaxmalarda qanaxmanı dayandırmaq və erkən təkrarlanmanı önləmək üçün istifadə edilir. Yöksək doz infuziyasının (500 mkq/saat) daha effektiv olduğu haqqında məlumatlar var

Oktreotid somatostatinin sintetik analoqu olub, somatostatinə nəzərən uzun müddətli təsirə malikdir. Göstəriş və təsir effektivliyi somatostatinlə eynidir. Qanaxmalarda ilk olaraq $50 \mathrm{mkq}$ doza venadaxilinə yeridilir və sonra saatda $50-100 \mathrm{mkq} / \mathrm{saat}$ dozada infuziya edilir. Oksər hallarda 5-7 gün istifadə edilir. Bəzi müəlliflər dərialtı yeritməklə $(5 \mathrm{mkq} / \mathrm{kq}) 15$ günə qədər istifadə edirlər.

Somatostatin və oktreotidin müsbət cəhəti ümumi hemodinamikanı ciddi dəyişdirməməsi, mənfi cəhəti isə, immunosupressiv təsir göstərməsidir.

Vazopressin və analoqları (qlipressin, terlipressin) güclü damardaraldıcı təsirə malikdirlər. Vazopressin (oksitosin) hipofizin arxa payından ifraz olunan hormondur, saya əzələlərdə spazm törədə bilir. Splanxik arteriyalarda spazm nəticəsində portal təzyiq azalır. Lakin, vazopressin koronar damarlarda da spazm törədərək işemiyaya səbəb ola bilir. Ona görə də bu dərman nitroqliserinlə birlikdə istifadə edilməlidir (vasopressin 0,4 TV/dəq infuziya 24-48 saat + dilaltı nitroqliserin hər 4 saatda bir) Vazopressinin sintetik analoqları olan qlipressin vo terlipressin koronar damarlara təsir göstərmədiyi üçün sərbəst istifadə edilə bilir. Terlipressinin standart dozası ilk gün $2 \mathrm{mq}$ hər 4 saatda, sonrakı günlərdə (5-7 gün) $1 \mathrm{mq}$ hər 4 saatda bir təşkil edir Somatostatin kimi vazopressin və analoqları da kəskin qanaxmalarda q1samüddətli istifadə edilir. Vazopressin və somatostatin qrupu dərmanlar arasında qanaxmanı dayandırmaq üzrə ciddi fərq tapılmamışdır.

$\beta$-adrenoblokatorlar (propranalol, anaprilil, nadolol) bir tərəfdən ürək fəaliyyətini azaldaraq, digər tərəfdən splanxik arteriyalarda $\beta$-reseptorları blokada edib $\alpha$ reseptorların üstünlüyünə - vazospazma səbəb olaraq portal təzyiqi azaldırlar. $\beta$ adrenoblokatorlardan on çox istifadə olunan propnanalol və nadololdur. $\mathrm{Bu}$ 
dərmanların dozası fərdi seçilir və nəbzi və arterial təzyiqi $25 \%$ azaltması yetərli sayılır. Adətən propnanalol 10-40 mq/gün dozada istifadə edilir. $\beta$-blokatorlar qanaxmanı dayandırmaq üçün yox, profilaktikası üçün tətbiq edilir.

Digər dərmanlar (nitroqliserin, izosorbid, klonidin) geniş tətbiq tapmamışdır. Son illər qaraciyərdəxili damarları genişləndirə bilən dərmanların axtarışına geniş diqqət edilməkdədir. Təəssüf ki, hələlik bu istiqamətdə ciddi irəliləmələr qeyd edilmir.

\section{Cərrahi üsullar}

\section{Porto-kaval şunt vo ya yanyol (PKYY)}

Porto-kaval şunt və ya yanyol (PKYY) mahiyyətcə portal sistemlə aşağı boş vena və ya şaxələri arasında anastomoz yaratmaqdır. Nəticədə qan yüksək təzyiqli qap1 sistemindən aşağ 1 təzyiqli boş venaya axır və portal sistemdə təzyiq aşağ düşür. $\mathrm{Bu}$ əməliyyatlar PH-1 azaltmaq üçün ən effektiv tədbir sayılır. Lakin PKYY nəticəsində portal qanın bir hissəsi (bəzən əksəriyyəti) qaraciyərdən yan keçdiyi üçün iki ciddi problem törədir. Birincisi, qaraciyərin trofikası pozulur (portal qan Qc üçün çox vacib trofiki amildir) və hepatosellular yetməzlik dərinləşir. İkincisi, qaraciyərdən yan keçən - zərərsizləşməmiş portal qan ensefalopatiyaya səbəb olur. Ona görə də PKYY əməliyyatları digər tədbirlər effektsiz olduqda və Qc funksiyası saxlanılan hallarda istifadə olunur. PKYY-nin müxtəlif növləri təklif edilmişdir və portal axını nə dərəcədə dəyişdirdiyinə görə bunları 3 qrupda cəmləşdirmək olar: ümumi, selektiv və hissavi.

Ümumi (və ya total) yanyol əməliyyatları həm çöz, həm də dalaq venasından gələn qanın əksər hissəsini aşağı boş venaya yönəldir. Selektiv yanyol əməliyyatlarında qapı venasının iki hövzəsi (dalaq və çöz) arasındakı əlaqə kəsilir, dalaq hövzəsi boş vena sisteminə yönləndirilir, çöz sistemi isə, əvvəlki yolu ilə Qc-ə axır. Hissəvi yanyollar mahiyyətcə kiçik diametrli ümumi şuntlardır.

\section{Ümumi (total) yanyollar}

Qeyd edildiyi kimi, ümumi PKYY-larda portal sistemin hər iki hövzəsindən çıxan qanın çox hisəssi aşağı boş venaya yönləndirilir. Bunun üçün qapı venası və ya böyük şaxələri ilə aşağı boş vena və ya şaxələri arasında geniş (>1 sm) anastomozlar yaradılır: 
yan-yan PKYY, uc-yan PKYY, proksimal spleno-renal YY, mezo-kaval YY, proksimal spleno-kaval yanyol və s (Şəkil 1, 2). Qeyd etmək lazımdır ki, yerindən asılı olmayaraq ümumi PKYY-lardan sonrakı qısa müddətdə portal qanın əksər hissəsi boş venaya yönəlir. Həttda, qaraciyərdən retroqrad axın baş verir (qaraciyərə gələn arterial qan sinusoidlərdən keçməyib portal damarlarla geriyə qayıdaraq YY-a yönəlir). Ona görə də, hepatosellular yetməzlik dərinləşir və ensefalopatiya inkişaf edir ( $40 \%)$. Qc-dən retroqrad axını önləmək üçün uc-yan PKYY tövsiyə edilsə də, problemlər aradan qalxmır. Qc qangəlimini qorumaq üçün ümumi yanyollara əlavə olaraq tətbiq edilən portal arterializasiya və arterial simpatektomiya əməliyyatları da bu problemləri həll etməmişdir. Ona görə də, ümumi PKYY əməliyyatları sirroz mənşəli PH-da demək olar ki, istifadə olunmur, Qc funksiyası pozulmayan PH-da isə digər üsullar (selektiv PKYY, endoskopik, medikamentoz) effekt vermədikdə tövsiyə edilir.

\section{Hissavi yanyollar}

Hissəvi PKYY əməliyyatlarında portal vena və ya böyük şaxələri (çöz və ya dalaq venaları) ilə aşağı boş vena və ya şaxələri (adətən böyrək venası) arasında kiçik diametrli (8 mm) damar protezləri yerləşdirilir (Şəkil 1, 2). Bu YY-a bəzən «H» tipli şuntlar da deyilir. Ümumi PKYY-dən fərqli olaraq «H» tipli YY-da damar diametri nisbətən kiçik olduğu üçün və böyümədiyinə görə portal qanın əksəriyyəti Qc-dən yan keçmir, trofika saxlanılır və ensefalopatiya nisbətən az rast gəlir. Lakin, bu anastomozların tıxanma halları yüksəkdir və antikoaqulyant tələb olunur. Hissəvi PKYY-lar əsasən Qc funksiyası saxlanılan və portal trombozu olmayan hallarda (Baddi-Kiari, anadangəlmə hepatik fibroz) tövisyə olunur.

\section{Selektiv yanyollar}

Yuxarda göstərildiyi kimi selektiv YY-ların fərqləndirici cəhətləri ondan ibarətdir ki, qapı venoz sisteminin iki bölgəsi - dalaq və çöz hövzələri arasında əlaqə kəsilir, dalaq hövzəsinin qanı aşağı boş venaya yönəldilir, bağırsaq qanı isə, təbii yolu ilə qaraciyərə gedir (Şəkil 2). Nəticədə, bir tərəfdən qastro-ezofaqo-splenik bölgədə təzyiq düşdüyü üçün qanaxma, qastropatiya və splenomeqaliya kimi ă̆ırlaşmalar aradan qalxır. 


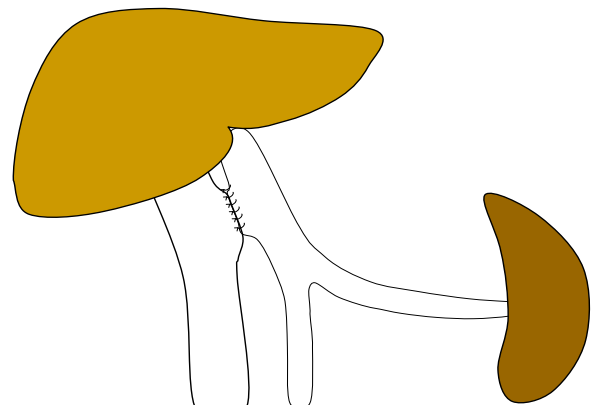

Yan-yan PKYY

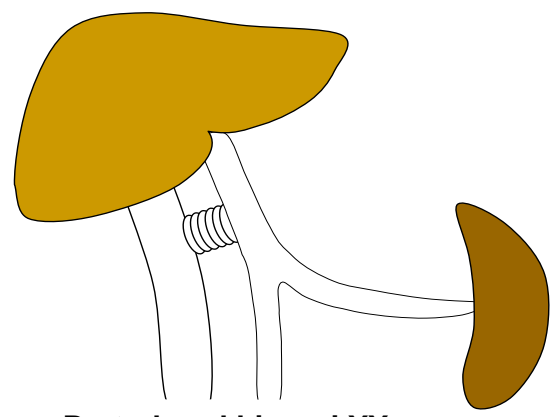

Porto-kaval hissovi YY

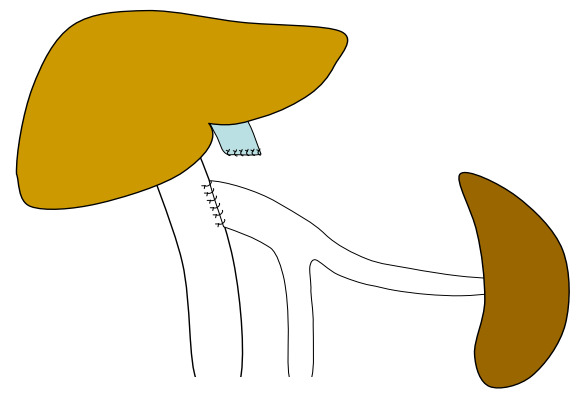

Uc-yan PKYY

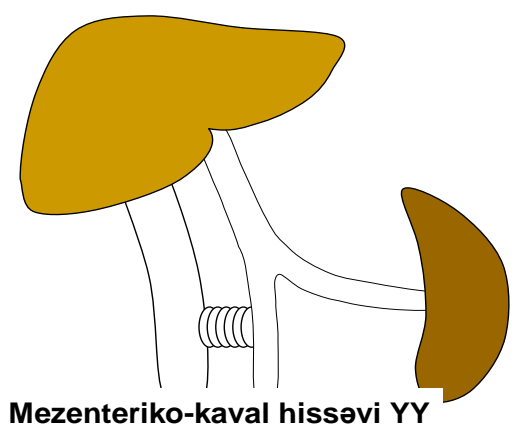

Şəkil 1. Porto-kaval yanyol əməliyyatları

Digər tərəfdən isə, nisbətən toksik olan mezenterik qan Qc-ə getdiyi üçün hepatosellular funksiya pozulmur, ensefalopatiya çox az rast galir (5-8\%). Üçüncüsü isə, dalaq hövzəsi portal sistemdən ayrıldığı üçün retroqrad axın baş vermir və hepatosellular yetməzlik dərinləşmir. Dördüncüsü, dalaq salxanılır. Bu müsbət cəhətlərinə görə selektiv YY-lar PKYY arasında ən yaxşısı hesab olunur. Lakin, bu şuntlar nə qədər «yaxşı» görünsələr də, qüsursuz deyillər.

Birincisi, bu yanyollar az da olsa, hepatosellular disfunksiya və ensefalopatiya törədirlər. Çünki, Qc üçün «trofiki faktorlar» splenik hövzədən də gəlir və bu hövzə qanının da zərərsizləşməyə ehtiyacı var. İkincisi, selektiv yanyollarda MAV arxası geniş diseksiya olduğu üçün limfatik damarlar zədələnir və assit arta bilir. Ona görə də, refraktor assitlərdə tövisyə olunmur. Üçüncüsü, bəzi hallarda (splenektomiya, dalaq venası trombozu) bu əməliyyatları yerinə yetirmək mümkün olmur.

Hazırda selektiv YY-ın bir neçə üsulu mövcuddur: distal spleno-renal, distal splenokaval, qastrorenal va mezo-portal.

Distal spleno-penal yanyol (DSRYY) əməliyyatında prinsipial olaraq üç mərhələ həyata keçirilir. Birinci mərhələdə dalaq venası səfərbər edilir. Bu məqsədlə piylik cibi açılır, MAV cismi və quyruğu aşağı kənardan başlayaraq yuxarıya qaldırlır, dalaq 
venasına açılan şaxələr bağlanıb kəsilir. İkinci mərhələdə dalaq venası hovuzu ilə qapı venası arasında əlaqə kəsilir: aşağı çöz venası, mədədən qapı venasına və çöz venasına açılan venalar bağlanıb kəsilir və nəhayət dalaq venası yuxarı çöz venasına birləşən yerdə kəsilir.

Üçüncü mərhələdə isə, dalaq venası ilə sol böyrək venası arasında anastomoz qoyulur. Ogər böyrək venası uyğun olmazsa (retro-aortik renal vena) splenik vena aşağı boş venaya calana bilər və bu üsul distal-spleno-kaval yanyol (DSKYY) adlanır.

Üçüncü üsul olan qastro-renal yanyol əməliyyatında qapı venası ilə spleno-qastrik hovuz arasında əlaqə kəsildikdən sonra mədənin böyük venası sayılan tac venası (sol mədə venası) ilə renal vena arasında anastomoz qoyulur. Bu üsul DSRYY mümkün olmadıqda seçilir.

Mezenteriko-portal yanyol aməliyyatında (Rex şuntu) qaraciyərin sol qapı venası ilə çöz venası arasında venoz ələqə yaradılır. Olaqə üçün vidaci vena istifadə edilir. $\mathrm{Bu}$ əməliyyat uşaqlarda ana portal vena trombozunda mezenterik vena açıq olarsa tövsiyə edilir.

Yanyol amaliyyatının qarşılıqlı müqayisəsi

Porto-kaval yanyol əməliyyatlarını üç əsas praktik cəhətlərinə görə müqayisə etmək olar:

- Portal hipertenziyanı azaltma dərəcəsinin dolayı göstəricisi kimi, varikoz qanaxmanin takrarlanması

- Portal qanın yan keçmə dərəcəsinin göstəricisi kimi, ensefalopatiyaya

- Cərrahi travma və hepatosellular disfunksiyanın göstəricisi kimi, letallıq

Varikoz qanaxmanın təkrarlanması PKYY əməliyyatlarından sonra 5-15\% arasında rast gəlir. Qanaxma ən çox kiçik diametrli («H»-tipli, hissəvi) yanyol əməliyyatlarından sonra rast gəlir və adətən anastomozun trombozuna bağlı olur. Qanaxmaya görə selektiv və ümumi yanyollar arasında ciddi fərq görünmür. Beləliklə, yanyollar PH-ı effektiv dorocodo aşağı salır vo qanaxmanı önloyirlor. 


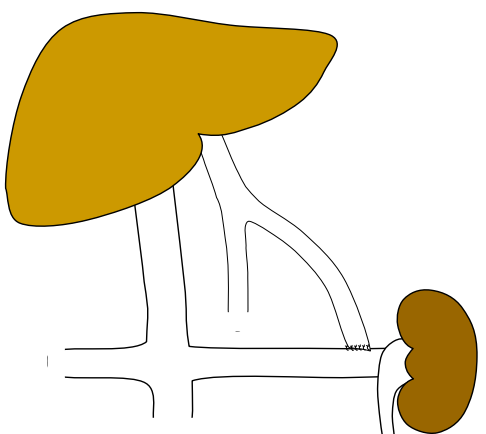

Proksimal spleno-renal YY

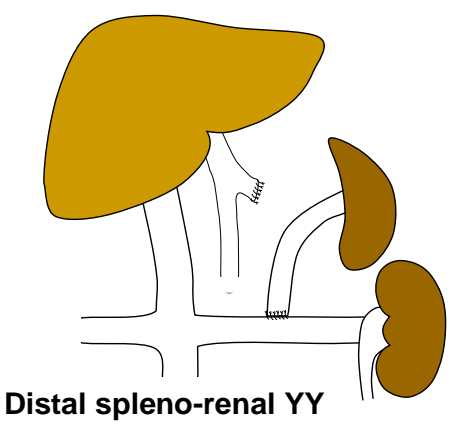

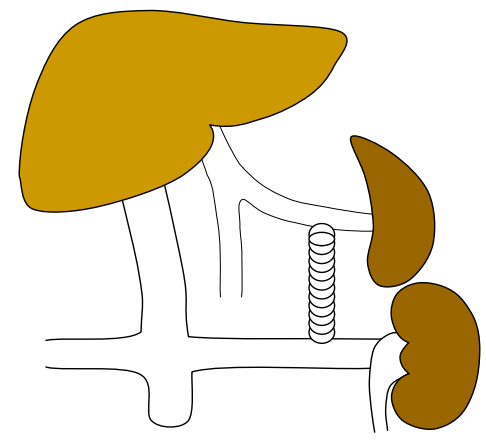

Splenorenal hissəvi YY

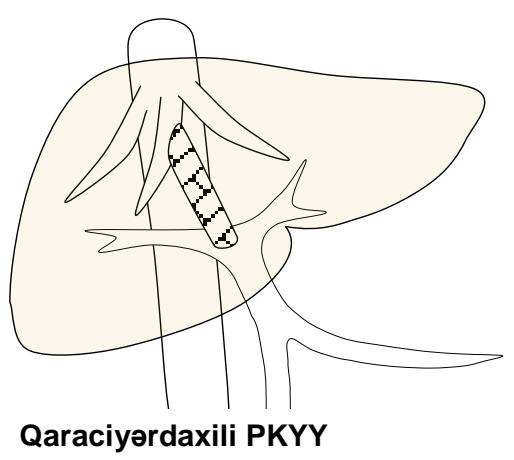

Şəkil 2. Porto-kaval yanyol əməliyyatları

Ensefalopatiya nöqteyi nəzərindən yanyollar arasında ciddi fərqlər ortaya çıxır. Selektiv yanyollarda ensefalopatiya $5-8 \%$ halda rast gəlirsə, ümumi yanyol əməliyyatlarında bu göstərici çox yüksək (40-50\%) səviyyədə rast gəlir.

Letallıq nəzərdən keçirilərsə, selektiv və hissəvi yanyollarda 3-5\%, ümumi yanyolda $10-15 \%$ rast gəlir.

Beləliklə, PKYY əməliyyatları müalicəvi effektlə yanaşı ( $\mathrm{PH}-1$ və qanaxmanı azaltma) ensefalopatiya və hepatosellular disfunksiyanı dərinləşdirmə kimi ciddi ağırlaşmalar da törədirlər. Ona görə də, $P H$-ı azaltma, ensefalopatiyanı artırmama va Qc-ə portal qangalimi qoruma PH müalicasina qoyulan asas talablardandir. Selektiv yanyol «ən yaxşı» üsul görünsə də, hazırda bu tələblərə tam cavab verən ideal müalicə üsulu yoxdur. Qc qangəlimini qorumaq üçün ümumi yanyollara əlavə olaraq tətbiq edilən portal arterializasiya və arterial simpatektomiya əməliyyatları da bu problemləri həll etməmişdir.

Bunları nəzərə alaraq, hazırda PH müalicəsində yanyol üsulunun seçimində iki cəhətə diqqət yetirilir. Birincisi, yanyol əməliyyatı ağır Qc yetməzliyi (Child C) hallarında 
istifadə edilməməlidir. İkincisi, üsul seçimində Qc-in qangəlimini qoruyan üsullara üstünlük verilməlidir. Ümumi yanyollar az istifadə olunur. Selektiv yanyollar ilk seçim sayılır. Xüsusən, qastrik varikoz və qastropatiyada selektiv şunt ən effektli müalicədir. Ogər, selektiv yanyol yerinə yetirilə bilmirsə hissəvi («H» tipli) yanyol seçilə bilər.

\section{Splenektomiya}

Keçən əsrin ortalarında PH azaltmaq üçün «portal hovuzu kiçiltmək» prinsipinə əsaslanaraq, splenektomiya əməliyyatı geniş tətbiq edilirdi. Təcrübə göstərdi ki, hətta splenomeqaliyalarda belə, splenektomiyadan qisa müddət sonra PH yenidən ortaya çıxır. Digər tərəfdən, splenektomiya xəstədə infeksion xəstəliklərə həssaslığı artırır. Ona görə də, hazırda PH-ın müalicəsi üçün splenektomiya hüdudlu göstərişlərlə aparılır. Dalaq venası trombozu və birincili splenomeqaliya splenektomiyaya əsas göstəriş sayılır. Sirrozda splenektomiya tövsiyə olunmur. Ogər hipersplenizm olarsa dəstək müalicəsi və böyümə faktorları (eritropoetin, GM-BF və trombositopoetin) istifadə edilir. Bunlar effekt vermədikdə dalaqqoruyucu əməliyyat - DSRYY, hissəvi dalaq embolizasiyası, dalaq arteriyasının stendlə daraldılması tətbiq edilə bilər. Splenektomiyaya məcburiyyəti yaranarsa autotransplantasiya edilməlidir.

\section{Endovaskulyar tədbirlər}

Endovaskulyar tədbirlər damardaxili müdaxilə yolu ilə həyata keçirilən işləmlərdir. Bunlar iki məqsədlə həyata keçirilir: portal sistemi boşaltma-dekompressiya və damarları embollaşdırma, daraltma.

\section{Qaraciyordaxili portokaval yanyol (QDPKYY)}

Portal dekompressiya məqsədi ilə aparılan və mahiyyətcə hissəvi porto-kaval yanyol olan qaraciyərdaxili portokaval yanyol (QDPKYY) əvvəllər PH-da geniş tətbiq edələn endovaskulyar müdaxilə idi. Bu üsul aşağıdakı kimi yerinə yetirilir. Angioqrafiya sistemi alatında katerterlə vidaci venadan keçərək qaraciyər venalarına daxil olunur. Qc venasından iynə ilə qaraciyərdaxili qapı venasına girilir və tel vasitəsi ilə iki vena 
arasında qaraciyərdaxili yol yaradılır. Bu "yol” balonla genişləndirilir və stend (çadır) yerləşdirilir. Qoyulan çadır yanyol rolu oynayaraq iki damar - qapı venası ilə Qc venası arasında qaraciyərdaxili əlaqə yaradır. Digər portokaval yanyollarda oldugu kimi QDPKYY da poratl təzyiqi azaldaraq qanaxmanın təkrarlama ehtimalını aşağı salır. Bu üsul aztravmatik olduğu üçün ağır xəstələrdə də apırıla bilir. Lakin, ensefalopatiya törətməsi və tezliklə tromblaşması ( 6 ay ərzində) bu üsulun çatışmayan cəhətləridir. Stendin trombozunda təkrari stend qoyula bilsə də, retromboz ehtimalı və qanaxmanın təkrarlama tezliyi yüksəkdir. Ona görə də, QDPKYY hazırda portal hipertenziyada müvəqqəti dekompressiya vasitəsi kimi qəbul olunur və Qc transplantasiyası gözləyən xəstələrdə qanaxmanı müvəqqəti dayandırmaq və qarşısını almaq məqsədi ilə tətbiq olunur.

\section{Hissovi dalaq embolizasiyast}

Hissəvi dalaq embolizasiyasında (HDE) dalaq arteriyasının dalaq daxilindəki bir və ya bir neçə şaxəsi embolizasiya edilərək dalaq toxumasının bir hissəsi nekroza uğradılır. Nekroz əksər hallarda fibrozla nəticələnir. Embologen maddə kimi polivinil alkoqoul və sianakrilat istifadə edilir. HDE splenomeqaliya, $\mathrm{PH}$ və hipersplenizmin müalicəsi üçün nəzərdə tutulur, dalaqqoruyucu tətbir kimi, splenektomiyaya alternativdir. Təkrari tətbiq edərək dalağı xeyli kiçiltmək olar. Bu işləmə ən uyğun göstəriş portal hipertenziya nəticəsində meydana gələn splenomeqaliya və hipersplenizmdir. $\mathrm{Bu}$ üsuldan travmatik xəstələrdə qanaxmanı dayandırmaq üçün də istifadə oluna bilər. Dalaqda nekroz və abses kimi ağırlaşma törətməsi HDE-nin geniş tətbiqinı əngəlləyir.

\section{Dalaq arteriyasının stendlo daraldılması}

$\mathrm{Bu}$ üsulun mahiyyəti ondan ibarətdir ki, dalaq arteriyasına diametri kiçik olan stend yerləşdirilir. Nəticədə dalağa gələn qan azalır və dalağın ölçüsü kiçilir. Embolizasiyadan fərqli olaraq bu üsulda dalaq toxumasında nekroz və ağırlaşmaları (dalaq absesı, dalaq venası trombozu) nisbətən az rast gəlir.

\section{Endovaskulyar varis embolizasiyast}

Endovaskulyar embolizasiya qanayan varikozları sklerozlaşdırmaq məqsədi ilə əvvəllər geniş istifadə edilmişdir. Lakin ağırlaşma hallarının (boyük damarların 
tromboemboliyası, trombozu) yüksək və təhlükəli olması ilə əlaqədar hazırda az hallarda istifadə edilir.

\section{Ağırlaşmaların profilaktika və müalicəsi}

PH-nın ağırlaşmaları arasında varikoz qanaxma, ensefalopatiya, assit, splenorenal sindrom, qastropatiya əsas yer tutur. $\mathrm{Bu}$ ağırlaşmaların profilaktika və müalicəsində PH-ı azaltmaqla yanaşı spesifik medikamentoz, endosokpik, endovaskulyar tədbirlər həyata keçirilir ki, bunlar barədə uyğun bölümlərdə məlumat verilir.

\section{Osas adobiyyat}

1. Ağayev B.A. Carrahi Xəstəliklar. Bak1 2001

2. Blumgart LH. Surgery of the Liver, Biliary tract and Pancreas. 4th ed. 2006

3. Cuschieri SA. Disorders of the liver. Module 10, p 321-374. in Cuschieri SA, Steel RJ, Moossa AR. Essentiale Surgical practice.. $4^{\text {th }} \mathrm{ed.} 2002$

4. Feldman M, Friedman LS, Sleisenger MH. Sleisenger and Fordtran's Gastrointestinal and Liver diseases. $7^{\text {th }}$ ed. Vol II, 2002.

5. Modern Surgical Care. 2 ed. Vol I, 1998

6. Oxford textbook of Surgery V.1, 2004

7. Rob and Smith's Hepatobiliary and Pancreatic Surgery. 2. ed. 1996

8. Sabiston. Textbook of Surgery 17 ed., 2006, p.1112-1143

9. Timothy DS, Steven AC. Liver. Chapter 30, p 1139-1186. in Schwartz” S Principles of Surgeryl8th ed., 2004

10. Thomas JN, Gordon AH. Pathophysology. International edition. 3th ed. P 369396, 2004

11. Sherlock S, Dooley J. Disease of the liver and biliary tract. 11-th ed. 2001

12. Sultanov H.A. Corrahi Xastaliklar. Bak1 2000

13. Surgical Anatomy and Embriology. Surgical Clinics of North America Vol 73, no 4, 1993

14. William RJ. Liver and Portal venouse system. In: Gerard MD, Lawrence WW, Current Surgical Diagnosis and Treatment. $12^{\text {th }}$ edition, 2006, p 539572

15. Zudema GD. Shackelford's Surgery of Alimentary tract, Vol III, 5th ed, 2006 


\section{Olava adobiyyat}

1. Chen WC, Lo GH, Tsai WL, Hsu PI, Lin CK, Lai KH. Emergency endoscopic variceal ligation versus somatostatin for acute esophageal variceal bleeding. J Chin Med Assoc. 2006 feb;69(2):60-7.

2. Deltenre P, Mathurin P, Barraud H, Bronowicki JP, Jacquet E, Puche P, Jaber S, Navarro F, Pageaux GP. Managing the complications of cirrhosis. Rev Prat. 2005 Sep 30;55(14):1555-63.

3. Debray D, Yousef N, Durand P. New management options for end-stage chronic liver disease and acute liver failure: potential for pediatric patients. Paediatr Drugs. 2006;8(1):1-13.

4. De Gottardi A, Dufour JF. Oesophageal and fundic variceal bleeding. Ther Umsch. 2006 May;63(5):295-9.

5. Elwood DR, Pomposelli JJ, Pomfret EA, Lewis WD, Jenkins RL. Distal splenorenal shunt: preferred treatment for recurrent variceal hemorrhage in the patient with well-compensated cirrhosis. Arch Surg. 2006 Apr;141(4):385-8; discussion 388.

6. Faint V. The pathophysiology of hepatic encephalopathy. Nurs Crit Care. 2006 Mar-Apr;11(2):69-74

7. Garcia-Tsao G. Portal hypertension. Curr Opin Gastroenterol. 2006 May;22(3):254-62

8. Henderson JM, Boyer TD, Kutner MH, Galloway JR, Rikkers LF, Jeffers LJ, Abu-Elmagd K, Connor J; DIVERT Study Group. Distal splenorenal shunt versus transjugular intrahepatic portal systematic shunt for variceal bleeding: a randomized trial. Gastroenterology. 2006 May;130(6):1643-51.

9. Iversen P, Hansen DA, Bender D, Rodell A, Munk OL, Cumming P, Keiding S. Portal hypertension. Curr Opin Gastroenterol. 2006 May;22(3):254-62.

10. Jacobi D, de Muret A, Arbeille B, Perarnau JM. Transjugular intrahepatic portosystemic shunt for the treatment of portal hypertension secondary to non-cirrhotic perisinusoidal hepatic fibrosis. Eur J Gastroenterol Hepatol. 2006 May;18(5):549-51.

11. Laleman W, Landeghem L, Wilmer A, Fevery J, Nevens F. Portal hypertension: from pathophysiology to clinical practice. Liver Int. 2005 Dec;25(6):1079-90.

12. Liu H, Gaskari SA, Lee SS. Cardiac and vascular changes in cirrhosis: pathogenic mechanisms. World J Gastroenterol. 2006 Feb 14;12(6):837-42.

13. Lay CS, Tsai YT, Lee FY, Lai YL, Yu CJ, Chen CB, Peng CY. Endoscopic variceal ligation versus propranolol in prophylaxis of first variceal bleeding in patients with cirrhosis. J Gastroenterol Hepatol. 2006 Feb;21(2):413-9.

14. Ling SC. Should children with esophageal varices receive beta-blockers for the primary prevention of variceal hemorrhage? Can J Gastroenterol. 2005 Nov;19(11):661-6.

15. Mathews RE Jr, McGuire BM, Estrada CA. Outpatient management of cirrhosis: a narrative review. South Med J. 2006 Jun;99(6):600-6.

16. May G, Musa D. Best evidence topic report. The use of intravenous terlipressin in non-variceal upper GI bleeds. Emerg Med J. 2006 May;23(5):400-1. 
17. Paramesh AS, Meiners R, Fairchild RB, Sane S, George M, Van ThielDH. Retroperitoneal varices presenting as an adrenal pseudotumor in a cirrhotic patient.WMJ. 2006 Jun;105(4):44-6.

18. Pal S, Radhakrishna P, Sahni P, Pande GK, Nundy S, Chattopadhyay TK.

Prophylactic surgery in non-cirrhotic portal fibrosis:is it worthwhile? Indian J Gastroenterol. 2005 Nov-Dec;24(6):239-42.

19. Rockey DC. Pharmacologic therapy for gastrointestinal bleeding due to portal hypertension and esophageal varices. Curr Gastroenterol Rep. 2006 Feb;8(1):7-13.

20. Sandhu BS, Sanyal AJ. Management of ascites in cirrhosis. Clin Liver Dis. 2005 Nov;9(4):715-32.

21. Wong F. The use of TIPS in chronic liver disease. Ann Hepatol. 2006 JanMar;5(1):5-15. 
Seminar 3

SİRROZ 


\section{TORIFI}

Sirroz xronik xəstəliklərin nəticəsi kimi meydana çıxan son dövr qaraciyər xəstəliyi olub, iki arxitektonika dəyişikliyin birlikdə olması ilə xarakterizə olunur:

- Fibroz - porto-portal, porto-kaval bölgədə yerləşən körpüşəkilli birləşdirici toxuma.

- Düyün - hepatositlərin regenerasiyası nəticəsində əmələ gəlir, lakin mərkəzi venasi olmur.

$\mathrm{Bu}$ iki morfoloji dəyişiklik arxitektonikanı pozmaqla yanaşı funksional pozulmaların da əsasında durur və sirrozu digər patoloqiyalardan fərqləndirir. Xüsusən, periportal sahədə (biliar obstruksiya, şistostoma, kongental hepatik fibroz və s.) və ya mərkəzi vena ətrafında (kardiak fibroz) birləşdirici toxumanın inkişafı ilə xarakterizə olunan hepatic fibroz klinik cəhətcə sirroza bənzəyir. Lakin regenerativ düyünün və körpüşəkilli fibroz atmalarının olması sirrozu hepatic fibrozdan fərqləndirir.

\section{Sirroz hazırda geriyadönmoz proses sayılır.}

Arxitektonika dəyişikliyi iki qrup patoloji proseslərə səbəb olur: xronik qaraciyər yetməzliyi və portal hipertenziya. Eyni zamanda sirroz digər bir geriyədönməz prosesə - xərçəngə meyl yaradır. Sirrozun baş verməsində iki qrup xəstəliklər - naməlum səbəblər və qaraciyərin xronik xəstəlikləri rol oynayır.

Belaliklə sirroz üçün 2-lor qaydası xarakterikdir:

Sirroz 2 qrup səbəbdən əmələ gəlir - xronik qaraciyər xəstaliklari və naməlum sabablar.

Sirroz üçün 2 dəyişiklik xarakterikdir - fibroz və düyün

Sirroz 2 qrup sindrom törədirlər - qaraciyər yetməzliyi va portal hipertenziya

Sirroz 2 cür geriyədönməzdir - özü geriyədönmür və ikinci geriyədönməz xəstəlik olan xərçəngi töradir.

\section{SOBӘLӘRI}

Qaraciyərin bilinən xronik xəstəliklərinin əksəriyyəti sirroza səbəb ola bilir. Lakin 30$40 \%$ hallarda sirrozun səbəbini müəyyənləşdirmək mümkün olmur. 


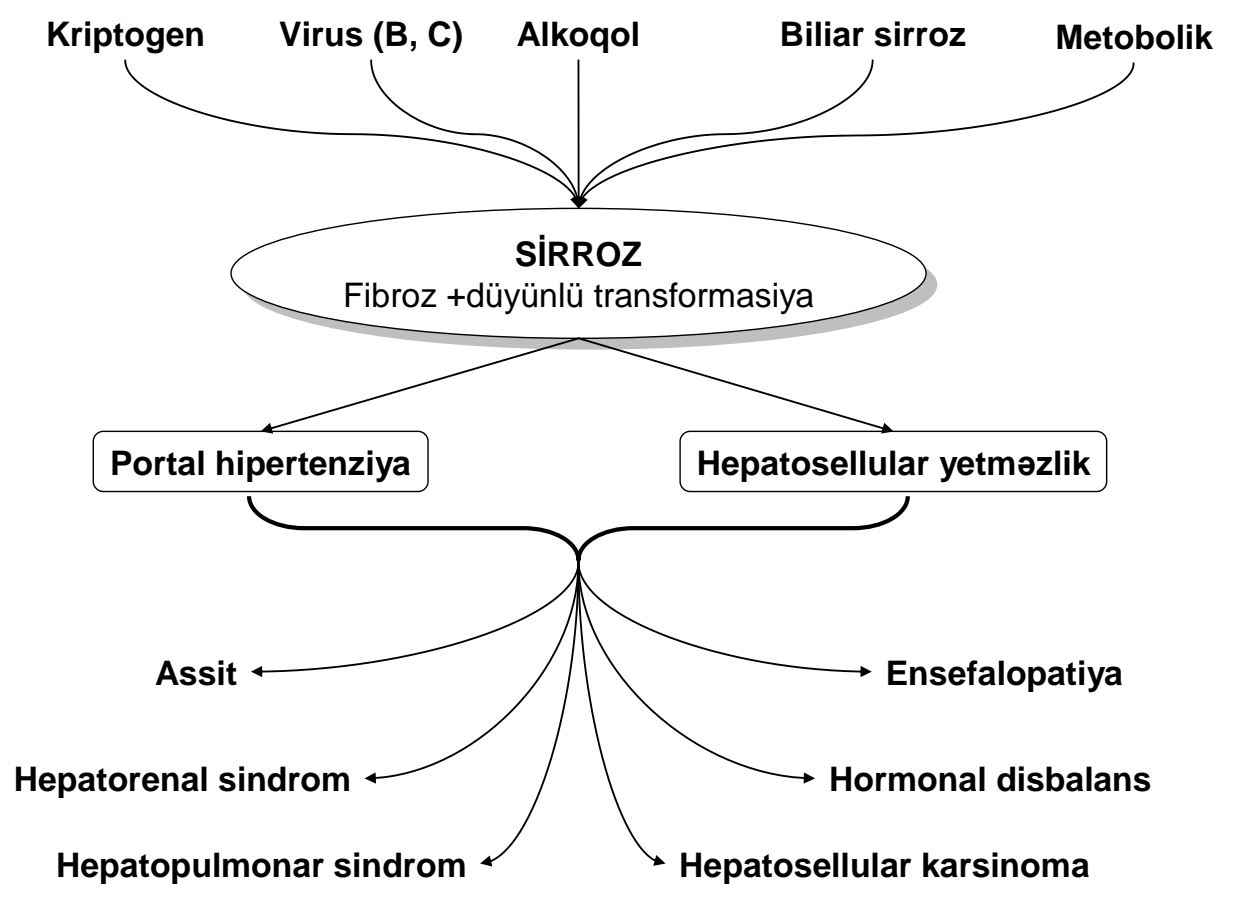

Şəkil 1. Sirrozun etiologiyası və patofiziologiyası

Ümumiyyətlə, sirrozun ən çox rast gələn səbəbləri aşağıdakılardır (Şəkil 1):

- Kriptogen - bilinməyən və ya tapılmayan

- Posthepatik - adətən xronik B və C hepatitlərinin nəticəsində inkişaf edir

- Alkoqol

- Birincili biliar sirroz

- Metabolik - Wilson xəstəliyi, hemoxromatoz və s.

\section{PATOGENEZİ}

Sirrozun inkişaf mexanizmi dəqiq məlum deyil.

Fibrozun əmələ gəlməsində iki mexanizm ehtimal edilir. Birincisi, hepatositlərin zədələnməsinə cavab kimi Kuppffer hüceyrələri və fibroblastların tərəfindən törənən xronik fibroplastik iltihabi reaksiya. İkincisi, sinusoidlərin divarında yerləşən Lito hüceyrələrinin - lipositlərin aktivləşməsi və kollagen sintezi.

Regenerativ düyünün quruluşca orginal paycıqdan fərqlənməsinin - mərkəzi venasının olmamasının mexanizmi məlum deyil. Lakin düyündəki hepatositlər fərqli şəraitdə (qan dövranı, öd axını və s.) olduğu üçün yetərli funksiya göstərə bilmirlər, 
zədələyici amillərə yüksək həssas olurlar. Bu da düyünün zədələnməsinə, yenidən fibroza və yeni düyün əmələ gəlməsinə gətirib çıxarır. Beləliklə, “zədələnmə $\rightarrow$ fibroz, düyün $\rightarrow$ duyun zədələnməsi $\rightarrow$ fibroz və düyün $\rightarrow$ » zənciri davam edir. Sirrozun inkişaf mexanizmi məlum olmasa da, törətdiyi dəyişikliklər geniş öyrənilmişdir. Fibroz va regenerativ düyün iki qrup prosesa səbəb olur (hepatosellular yetmozlik va PH), iki qrup prosesa iso (tokrari zadolonmoloro vo xərçəngə), meyl yaradır.

Artan fibroz hepatositlərin yerini alır, portal sahələri kiçildir, sinusoid sayını azaldır, arterio-venoz şuntlara səbəb olur, sağlam hepatositlərin qidalanmasını azaldır. Düyündə mərkəzi venanın olmaması və ətrafındakı fibroza bağlı hepatositlərin qan təhcizatı pozulur. Bunların noticəsi olaraq qaraciyər yetməzliyi və portal hipertenziya meydana gəlir.

Portal hipertenziya varikozlar, qanaxma, splenomeqaliya, assit əlamətləri ilə biruzə verir. PH sirrozun ən xarakterik əlamətidir və sirroz PH-1n ən çox rast gələn səbəbidir. Sirrozda PH-ın baş vermə mexanizmi əvvəlki bölümdə (Seminar 1) geniş şərh edilmişdir.

Qaraciyər yetməzliyi özünü sarılıq, xolestaz, koaqulopatiya, hipoalbumnemiya, və ensofalopatiya, hepatotorenal və hepatopulmonal sindrom şəkilində göstərir.

Düyündəki hepatositlər şəkilcə normal görünsələr də, funksional cəhətcə və təhcizat nöqteyi-nəzərdən yetərli deyillər. Bu da onların zədələyici amillərə həssaslığını izah edir. Stress, infeksiya, işemiya, dərman, alkoqol və s. amillər sirrotik xəstələrdə ağır qaraciyər yetməzliyi törədə bilərlər. Heç bir əlavə təsir olamadan sirrotik xəstələrdə kiçik əməliyyatlar $10 \%$, orta əməliyyatlar $30 \%$, böyük əməliyyatlar isə, $50 \%$ halda ölümə səbəb ola bilər. Bu bir tərəfdən hepatosellular yetməzliklə, digər tərəfdən zədələnməyə həssaslıqla bağlıdır.

Sirroz qərb ölkələrində hepatosellular xərçəngin (HSX) ən çox rast gələn səbəbidir. HSX-i olan xəstələrin 80-90\%-ində sirroz rast gəlir. Hesab edilir ki, regenerator aktivlik və arxitektonika pozulması (ilk baxışda sirrozdakı morfoloji dəyişiklik displaziyanı xatırladır) buna şərait yaradır. Təbii ki, bütün xəstəliklərdə olduğu kimi, sirrozda da genetik pozulmalar əsas rol oynayır. Xüsusən, hepatit B virusu və hemoxromatoz mənşəli sirrozlarda HSX tezliyi yüksəkdir. Yəni, sirroz «xronik hepatit - sirroz - xərçəng» prosesinin kilid nöqtəsidir. 


\section{TOSNIFATI}

Sirroz səbəbinə, morfoloji dəyişikliyinə, xarakterinə, ağırlıq dərəcələrinə görə təsnif edilir.

Sabablarina göra sirrozun idiopatik (kriptogen), posthepatitik, alkoqol, biliar və digər növləri ayrıd edilir.

Morfoloji dəyişikliklərə görə təsnifatda fibroz və düyünlərin nisbəti, ölçüsü nəzərə alınır. Makronodulyar sirrozda düyünlər 3 sm-dən böyük olur. On çox viral və autoimmun xronik hepatitlərdən sonra inkişaf edən sirrozlarda rast gəlir. Mikronodulyar sirrozda düyünlər 3 sm-dən kiçik olur, fibroz üstünlük təşkil edir. Buna portal sirroz da deyilir və ən çox alkoqol sirrozunda və kriptogen sirrozda rast gəlir.

Qarışıq sirrozda 3 sm-dən böyük və kiçik düyünlər eyni miqdardadır.

Ağırlıq dərəcəsinin təyini üçün müxtəlif təsnifatlar var və ən çox yayılan təsnifat Child tasnifatıdır (Codval 1).

\section{Codval 1. Child tosnifatı}

\begin{tabular}{|lccc|}
\hline Göstərici & A & Dərəcə & C \\
& Kompensasiya & B & Subkompensasiya \\
Assit & yox & Zəif və ya & Dekompensasiya \\
& & $\begin{array}{c}\text { Diuretikləazalmır } \\
\text { diuretiklə kontrol } \\
\text { olunur }\end{array}$ \\
Albumin $(\mathrm{q} / \mathrm{dl})$ & $>3,5$ & $2,8-3,5$ & \\
Bilirubin $(\mathrm{mq} / \mathrm{dl})$ & $<2$ & $2-3$ & $<2,8$ \\
\hline
\end{tabular}

$\mathrm{Bu}$ təsnifatda qaraciyərin sintetik (albumin), detoksikasiya (bilirubin) göstəricilərinə və portal hipertenziyaya (assit) görə 3 ağırlıq dərəcəsi ayrıd edilir: A, B, C. İlkin dərəcədə (A) qaraciyər funksiyaları normal səviyyədədir və buna kompensasiya mərhələsi də deyilir. B dərəcəsində qaraciyər funksiyalarıda yüngül və ya düzələ bilən dəyişiklik meydana gəlir. Buna subkompensasiya mərhələsi də deyilir. C dərəcəsi dekompensasiya mərhələsidir və funksiyalarda ciddi, çətin düzələn dəyişikliklər baş verir.

Child klassifikasiyasının müxtəlif variantları mövcuddur. Bunlar arasında ən şox istifadə olunanı Child-Turcotte-Pugh təsnifatıdır ki, bunda orginal təsnifatdakı göstəricilərə ensefalopatiya və protrombin aktivasiyası da əlavə olunur (Cədval 2). 


\section{Cadval 2. Child-Turcotte-Pugh tosnifatı}

\begin{tabular}{|c|c|c|c|}
\hline \multirow[t]{2}{*}{ Göstərici } & \multicolumn{3}{|c|}{ Bal qiyməti } \\
\hline & 1 & 2 & 3 \\
\hline Ensefalopatiya & yox & $1-2$ & $3-4$ \\
\hline Assit & yox & $\begin{array}{c}\text { Zaif və ya } \\
\text { diuretiklə } \\
\text { kontrol } \\
\text { olunur }\end{array}$ & $\begin{array}{l}\text { Diuretiklə } \\
\text { azalmır }\end{array}$ \\
\hline Protrombin zamanı & & & \\
\hline Normadan artma miqdarı (san) & $<4$ & $4-6$ & $>6$ \\
\hline INR & $<1,7$ & $1,7-2,3$ & $>2,3$ \\
\hline Albumin (q/dl) & $>3,5$ & $2,8-3,5$ & $<2,8$ \\
\hline Bilirubin (mq/dl) & $<2$ & $2-3$ & $>3$ \\
\hline
\end{tabular}

Qaraciyər xəstəliklərinin ağırlıq dərəcəsini qiymətləndirmək və proqnozu müəyyənləşdirmək üçün istifadə olunan təsnifatlardan biri də $\boldsymbol{M E L D}$ (model of endstage liver disease) şkalasıdır (Codval 3). Bu sistemdə kreatinin, bilirubin və protrombin səviyyəsi nəzərə alınaraq loqarifmik düsturla qimət hesablanır. Child təsnifatından fərqli olaraq MELD sistemindəki göstəricilər obyektiv və ölçülən dəyərlərdir. Son tədqiqatlar gıstərir ki, MELD təsnifatı qaraciyərin vəziyyətini və xəstənin proqnozunu daha obyektiv və dəqiq göstərir.

\section{Codval 3. MELD (model of end-stage liver disease) şkalası}

\begin{tabular}{|ll} 
Göstərici & Regrassiya koofisenti \\
\hline Kreatinin ( $\log _{\mathrm{e}}$ miqdarı) & 0,957 \\
Bilirubin (Loge miqdarı) & 0,378 \\
Protrombin zamanı - INR ( $\log _{\mathrm{e}}$ miqdarı) & 1,120 \\
Etiologiyas1* & 0,643 \\
& \\
& \\
Proqnostik risk aşağıdakı düsturla hesablanır: & \\
R= 0,957 x Loge (kreatinin mq/dl) + 0,378 x Loge (bilirubin $\mathbf{~ m q / d l ) ~ + ~} \mathbf{1 , 1 2 0} \mathbf{x}$ \\
Loge (INR) + 0,643 x (etiologiya) \\
Etiologiyanı qiymətləndirərkən, alkoqol və xolestatik xəstəliklərdə 0, digər \\
xəstəliklərdə isə 1 qiymət hesablanır.
\end{tabular}

\section{KLINIKK OLAMOTLORI}


Parenxima itirilməsinə və hepatocellular disfunksiyaya bağlı qaraciyər yetməzliyi, fibroz və arxitektonika dəyişikliklərlə bağlı portal hipertenziya sirrozun gediş tipini, klinik, labarator, görüntüləmə əlamətlərini müəyyən edir.

Qaraciyərin disfunksiyası adətən xronik şəkildə olur, bəzi ağırlaşdırıcı amillərin təsiri ilə kəskinləşə bilir.

Sarllıq adətən zəif (< $100 \mathrm{mmol} / \mathrm{l})$ və hər iki bilirubin fraksiyasının artması ilə xarakterizə olunur. Xolestaz adətən xolestatik sirrozda (birincili biliar sirroz) rastlanır, birləşmiş bilirubinin daha çox artması və QF artması ilə xarakterikdir.

Koaqulyasiya pozulmaları laxtalanma faktorlarının sintezinin və fibrinolitik amillərin (fibrinolizin, t-PA) neytrallaşmasının azalmasına bağlıdır. Hipokoaqulyasiya adətən K vitamininin müalicəsi ilə ciddi yaxşılaşmır.

Ensefalopatiya zəif xronik şəkildə, bəzən də ağır koma şəkilində ortaya çıxır.

Detoksikasiya zəifləməsi ümumi əlamətlər və orqan spesifik sindromlarla ortaya çıxa bilir.

- Ümumi əlamətlər - yorğunluq, zəiflik, arıqlama

- Steroid detoksikasiyasının zəifləməsi (estrogen, progestron, aldesteron artıqlığı) - palmar eritema, angioma, ginekomastiya, impotensiya, ödem, assit

- Hepatorenal, hepatorulmonar sindromlar.

- Digərləri - anemiya, xora xəstəliyi, paratiroid böyüməsi və s.

Portal hipertenziya adətən assit, kollateral venaların varikozu, splenomeqaliya, qastropatiya, ensefalopatiya şəklində biruzə verir və sirrozun ən xarakerik əlaməti sayılır. Sirrozun PH törətmə mexanizmi ilə əlaqədar geniş məlumat əvvəlki bölümlərdə verilmişdir.

\section{DİAQNOSTIKASI}

Xəstədə bəzi əlamətlər, xüsusən xroniki qaraciyər əlamətləri (zəiflik, tez yorulma, palmar eritema, qırmızı dil, angioektaziyalar) sirroza şübhə yaradır. Portal hipertenziyanın olması, görüntüləmədə kələkötür qaraciyər, qaraciyər venalarının dəqiq seçilməməsi, öd kisəsi divarının qalınlaşması və s. əlamətlər sirrozun dolayı əlamətləri say1lır. 
Sirrozun dəqiq diaqnozu patohistoloji müayinə ilə qoyulur. Histoloji müayinədə qaraciyərdə fibrozun və düyünün birlikdə olması sirroz üçün xarakterikdir. Bununla yanaşı nekroz da rastlana bilər.

Qeyd etmək lazımdır ki, bəzi xronik qaraciyər xəstəlikləri (xronik hepatitlər, hepatic fibroz və s.) klinik olaraq sirroza bənzəyə bilər. Digər tərəfdən sirroz erkən mərhələlərdə klinik olaraq ortaya çıxmaya bilir. Ona görə də, klinik və görüntüləmə əlamətlərinə görə sirroz diaqnozu qoymaq səhv nəticə verə bilir. Bunları nəzərə alaraq, sirrozu dəqiqlaşdirmək üçün biopsiya etmək (punksiyon və ya laparoskopik) vacib şərtdir.

\section{MÜALİCəSi}

Hazırda sirroz geriyədönməz prosess sayılır və sirrozun radikal müalicəsi qaraciyər transplantasiyasıdır (Qc Tx). Qc Tx mümkün olmadıqda aparılan müalicələr sirrozun törətdiyi ağırlaşmaların profilaktikası və müalicəsinə yönəlmişdir. Çoxsayli tədqiqatlara və klinik təcrübələrə baxmayaraq hazırda sirrozlu xəstələrdə fibrotik prosesi aradn qaldırmaq üçün effektiv müalicə tədbiri yoxdur. Son illərdə interferon müalicəsinin viral sirrozlarda fibrotik prosesin inkişafını azaltığı qeyd edilməkdədir.

$\mathrm{Bu}$ kitabda PH ağırlaşmaların profilaktika və müalicəsi üçün qeyd edilən ümumi prinsiplər əsasən sirroz mənşəli PH üçün nəzərdə tutulur. Başqa mənşəli PH-ların özəllikləri uygun bölümlərdə verilir.

\section{Osas ədəbiyyat}

1. A Ăgayev B.A. Corrahi Xastaliklar. Bakı 2001

2. Blumgart LH. Surgery of the Liver, Biliary tract and Pancreas. 4th ed. 2006

3. Cuschieri SA. Disorders of the liver. Module 10, p 321-374. in Cuschieri SA, Steel RJ, Moossa AR. Essentiale Surgical practice.. $4^{\text {th }} \mathrm{ed} .2002$

4. Feldman M, Friedman LS, Sleisenger MH. Sleisenger and Fordtran's Gastrointestinal and Liver diseases. $7^{\mathrm{th}}$ ed. Vol II, 2002.

5. Modern Surgical Care. 2 ed. Vol I, 1998

6. Oxford textbook of Surgery V.1, 2004

7. Sabiston. Textbook of Surgery 17 ed., 2006, p.1112-1143

8. Timothy DS, Steven AC. Liver. Chapter 30, p 1139-1186. in Schwartz” ${ }_{S}$ Principles of Surgery 18th ed., 2004 
9. Thomas JN, Gordon AH. Pathophysology. International edition. 3th ed. P 369396, 2004

10. Sherlock S, Dooley J. Disease of the liver and biliary tract. 11-th ed. 2001

11. Sultanov H.A. Carrahi Xastaliklar. Bak1 2000

12. William RJ. Liver and Portal venouse system. In: Gerard MD, Lawrence WW, Current Surgical Diagnosis and Treatment. $12^{\text {th }}$ edition, 2006, p 539572

13. Zudema GD. Shackelford's Surgery of Alimentary tract, Vol III, 5th ed, 2006

\section{Olavə ədəbiyyat}

1. Mathews RE Jr, McGuire BM, Estrada CA. Outpatient management of cirrhosis: a narrative review. South Med J. 2006 Jun;99(6):600-6.

2. Deltenre P, Mathurin P, Barraud H, Bronowicki JP, Jacquet E, Puche P, Jaber S, Navarro F, Pageaux GP. Managing the complications of cirrhosis. Rev Prat. 2005 Sep 30;55(14):1555-63.

3. Dib N, Konate A, Oberti F, Cales P. Non-invasive diagnosis of portal hypertension in cirrhosis. Application to the primary prevention of varices. Gastroenterol Clin Biol. 2005 Oct;29(10):975-87.

4. Laleman W, Landeghem L, Wilmer A, Fevery J, Nevens F. Portal hypertension: from pathophysiology to clinical practice. Liver Int. 2005 Dec;25(6):1079-90.

5. Liu H, Gaskari SA, Lee SS. Cardiac and vascular changes in cirrhosis: pathogenic mechanisms. World J Gastroenterol. 2006 Feb 14;12(6):837-42.

6. Paramesh AS, Meiners R, Fairchild RB, Sane S, George M, Van ThielDH. Retroperitoneal varices presenting as an adrenal pseudotumor in a cirrhotic patient.WMJ. 2006 Jun;105(4):44-6.

7. Sandhu BS, Sanyal AJ. Management of ascites in cirrhosis. Clin Liver Dis. 2005 Nov;9(4):715-32.

8. Schepke M. Primary prevention of variceal bleeding in cirrhosis. Dtsch Med Wochenschr. 2006 Jun 2;131(22):1269-72.

9. Al Mardini H, Douglass A, Record C. Amino acid challenge in patients with cirrhosis and control subjects: ammonia, plasma amino acid and EEG changes. Metab Brain Dis. 2006 Mar;21(1):1-10. Epub 2006 May 4.

10. Ardizzone G, Arrigo A, Schellino MM, Stratta C, Valzan S, Skurzak S, Andruetto P, Panio A, Ballaris MA, Lavezzo B, Salizzoni M, Cerutti E. Neurological complications of liver cirrhosis and orthotopic liver transplant. Transplant Proc. 2006 Apr;38(3):789-92.

11. Jover R, Rodrigo R, Felipo V, Insausti R, Saez-Valero J, Garcia-Ayllon MS, Suarez I, Candela A, Compan A, Esteban A, Cauli O, Auso E, Rodriguez E, Gutierrez A, Girona E, Erceg S, Berbel P, Perez-Mateo M. Brain edema and inflammatory activation in bile duct ligated rats with diet-induced 
hyperammonemia: A model of hepatic encephalopathy in cirrhosis.

Hepatology. 2006 Jun;43(6):1257-66

12. Schepke M, Appenrodt B, Heller J, Zielinski J, Sauerbruch T. Prognostic factors for patients with cirrhosis and kidney dysfunction in the era of MELD: results of a prospective study. Liver Int. 2006 Sep;26(7):834-9. 
Seminar 4

\section{VARİKOZ VO \\ QANAXMA}




\section{QANAXMA MEXANIZMI}

PH-nın ən xarakterik əlaməti qapı venasının, onun şaxələrinin, porto-sistemik kollateralların genişlənməsidir və genişlənmə olmadıqda $\mathrm{PH}$ şübhəlidir.

Normal halda görüntüləmə (Dopler USM, KT, MRT angioqrafiyaları, endoskopiya) ilə portal vena diametri 10-12 mm təşkil edir və kollaterallar görünmür. Porto-kaval təzyiq fərqi $8 \mathrm{~mm} \mathrm{Hg}$ st. aşarsa venalarda və kollaterallarda genişlənmə başlayır, fərq $10 \mathrm{~mm} \mathrm{Hg}$ st. olduqda genişlənmə bariz şəkil alır, $12 \mathrm{~mm} \mathrm{Hg} \mathrm{st.} \mathrm{aşdıqda} \mathrm{isə,} \mathrm{qanaxma}$ təhlükəsi meydana gəlir. Kollateralların genişlənməsi ən çox qastroezofageal səviyyədə, sonra rektal, göbəkətrafı və retroperitoneal səviyyədə ortaya çıxır. Qeyd edildiyi kimi kollaterallar yenidən əmələ gələn anastomozlar olmayıb embrional hazır damarlardir.

Varikozlardan qanaxma PH-nın ən ağır ağırlaşmasıdır və endoskopik müalicələrə qədərki dövrlərdə sirrotik xəstələrin əsas ölüm səbəbi idi. Qanaxma ən çox qastroezofageal varislərdən, sonra rektal və göbəkətrafı varislərdən, çox nadir hallarda isə, retroperitoneal varislərdən baş verir. Portal venanın şaxələrindən intraabdominal qanaxma ehtimalı çox azdır və bu adətən travmaya (punksiya və küt travma) bağlı olur. Varikoz qanaxmanın baş vermə mexanizmi «partlama» nəzəriyyəsinə əsaslanır ki, bu da Laplas qanunu ilə izah oluna bilər. Bu qanun səthin gərilmə qüvvəsi ilə (G) divara düşən təzyiq (portal təzyiq - P), damar radiusu (p) və divar qalınlığı (d) arasında münasibəti göstərir. Gərilmə təzyiqi damardaxili təzyiq və radiusla düz, divar qalınlığı ilə tərs mütənasibdir.

$$
G=\frac{\operatorname{Pr}}{d}
$$

Gərilmə qüvvəsinin artmasını partlama törədən amil kimi qəbul etsək, onda görünür ki, portal təzyiqin artması böyük və incə divarlı damarlarda «partladıcı» qüvvəni daha çox artırır və qanaxmaya səbəb olur. Yəni genişlənmiş və incə divarlı damarların partlama ehtimalı daha çoxdur. Bu nəticə portal hemodinamikaya tətbiq olunan hidrodinamika qanunlarından çıxan ikinci böyük nəticədir. 


\section{Cadval 1. Varikoz qanaxmanın} risk amilləri

\section{Yerli amillər}

Böyük varislər (III, IV

dərəcəli)

İncə divar ("q1rmızı nöqtə", tumurcuq)

\section{Hemodinamik amillər}

Yüksək təzyiq (portokaval fərq $>12 \mathrm{mmHg}$ st.)

Portal hipervolemiya

Kollateral axın artışı?

Qarındaxili təzyiq artması?

\section{Qaraciyərin vəziyyəti}

Child A - az

Child B və C yüksəo

\section{Digər}

QSİ preparatlar

Bakterial infeksiya
(Birincisi, Om qanununa görə təzyiq ilə axın və müqavimət arasında əlaqə idi ki, PH1n patogenezini izah edirdi). Bu nəticə də, özünü praktikada müəyyən dərəcədə doğrultmuşdur. Birincisi, təcrübə göstərir ki, varikoz qanaxma adətən porto-sistemik fərq $12 \mathrm{~mm} \mathrm{Hg}$ st. çox olduqda baş verir. $\mathrm{Bu}$ təzyiqdən aşağı hallarda qanaxma ehtimalı azdir.

İkincisi, qanaxma adətən böyük və incə divarlı varikozlarda daha çox rast gəlir.

\section{Varikozlardan qanaxma riski}

Bütün varikozların qanaxma ehtimalı olsa da, hamıs1 mütləq qanaxma törətmir. Bəzi amillər varikozların qanama ehtimalını artırır. Bu amilləri 4 qrupa ayırmaq olar:

yerli, hemodinamika, qaraciyarin vaziyyati va digar (Cadval 1). Bəzi müəlliflər bu göstəricilərə əsasən şkalalar da təklif edirlər. Ümumiyyətlə baxılarsa, varikozun ölçüsü, divarın nazik olması, Qc-in vəziyyəti və portal təzyiq qanaxma riskini təyin edən ən önəmli amillər sayılır.

Ölçülərinə görə qida borusu varikozlarını 4 dərəcəyə ayırırlar:

I dərəcə - selikaltı qatda geniş vena, qabarmır

II dərəcə - mənfəzə doğru qabarmış venalar, mənfəzi tutmur

III dərəcə - qabarmış venalar mənfəzi tama yaxın tutur

IV dərəcə - qabarmış venalar mənfəzi tam tutur.

Divar incəlməsinin əlaməti isə «varis üzərində varis» (tumurcuq) və ya «q1rmızı ləkədir»».

Qaraciyərin vəziyyətini qiymətləndirmək üçün isə, Child və MELD klassifikasiyası istifado olunur. 


\section{VARIKKOZ QANAXMANIN TOBİI GEDİŞI}

Sirrotik xəstələrin təxminən 60\%-ində varikoz baş verir və bunların da təxminən $30 \%$ də 2 il ərzində qanaxma rast gəlir (Şəkil 1). Varikoz tapıldıqdan sonrakı iki il ərzində qanaxma olmursa, onun baş vermə ehtimalı azalır. Birinci dəfə baş verən qanaxma adətən 70-80\% hallarda öz-özünə və ya müalicə ilə dayanır. Lakin xəstələrin 60-70\%ində bir il ərzində təkrarlama baş verir və ən çox ilk saat və ya günlərdə ortaya çıxır. Qanaxmalarda letallıq təxminən 50\% təşkil edir. Hipertenziyanın səbəbi aradan qaldırıldıqda varislər geriyə inkişaf edir. Qanaxma qeyd edildiyi kimi, ən çox qastroezofageal varikozlardan baş verir. Lakin, mədənin fundal varikozlarından, hemorroidal varikozlardan da qanaxma baş verə bilər.

Varikoz qanaxma kəskin və xroniki anemiyaya səbəb olur, sirrotik xəstələrdə kəskin ensefalopatiya törədir. Mədə-bağırsaq boşluğuna tökülən qan parçalanaraq ammonyakın artışına və ensefalopatiyaya şərait yaradır. Ona görə də, sirrotik xəstələrdə ensefalopatiya dərinləşərsə varikoz qanaxma yoxlanılmalıdır.

\section{DİAQNOSTIKKASI}

Digər mədə-bağırsaq qanaxmaları kimi, varikoz qanaxmalar da iki qrup əlamətlərlə yerli (qanqusma, melena, NQZ-dan qangəlmə) və ümumi (anemiya, hipovolemiya, şok) əlamətlərlə büruzə verir. Sirrotik xəstələrdə ilk əlamət ensefalopatiya da ola bilər. Qanaxmanın intensivliyindən asılı olaraq bu əlamətlər zəif (melena, xroniki anemiya) və ya çox ağır (çoxlu qanqusma, hemorragik şok) şəkildə ortaya çıxa bilir. Nəzərə alınsa ki, varikoz qanaxma mədə-bağırsaq qanaxmaların ən çox rast gələn səbəblərindən biridir (xora, şiş və Mellori-Veys xəstəliyi kimi), sirrotik xəstələrdə varikozla yanaşı qanaxma törədən digər xəstəliklər də rast gələ bilir və PH qanaxmaya qədər subklinik gedə bilər, onda anamnezində Qc xəstəliyi olub-olmamasından asılı olmayaraq mədə-bağırsaq qanaxması olan bütün xəstələrdə varikoz qanaxmadan şübhələnmək lazımdır. Xronik qaraciyər xəstəliyi (palmar eritema, sarılıq, ensefalopatiya, ödem) və PH əlamətləri (göbəkətrafı geniş venalar, assit, splenomeqaliya) varsa varikoz qanaxma şübhəsi artır. Dəqiqləşdirmək üçün təcili endoskopiya aparılır. Endoskopiya həm diaqnostik (qanaxmanın yeri, intensivliyi, dayanıb-dayanmadığ 1 ), həm də müalicəvi məqsədlə aparılır. 


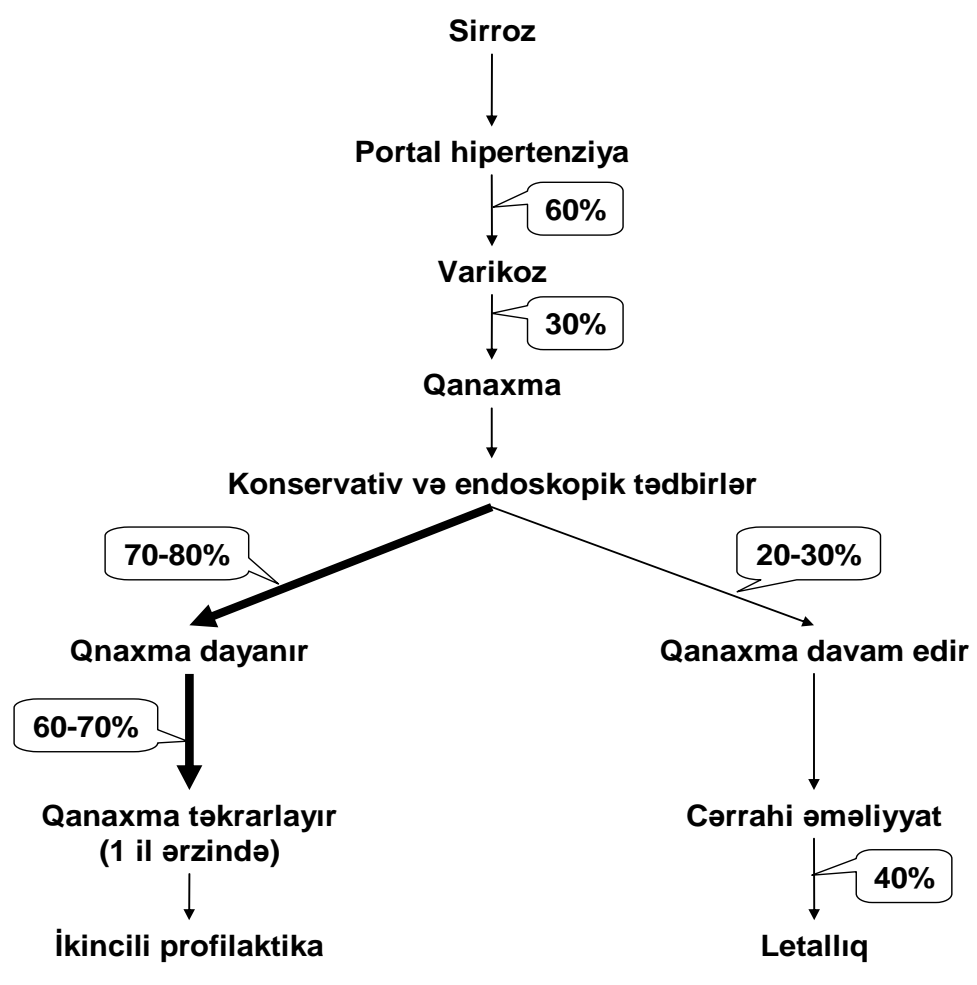

Şəkil 1. Varikoz və qanaxmanın təbii gedişi

\section{QIDAA BORUSU VARİKOZUNDAN QANAXMANIN MÜALİCOSI}

\section{Müalicə hədəfi}

Varikoz qanaxma həyati təhlükəli patologiyadır və təcili tədbirlər tələb edir. PH-ın əsas səbəbinin aradan qaldırılması varikoz qanaxmanın da radikal müalicəsidir. Məsələn, sirrozda Qc transplantasiyası, dalaq venası trombozunda splenektomiya, portal trombozda porto-kaval anastomoz və s. Lakin, bu tədbirlər bəzən imkansız olur və ya təcili vəziyyətlərdə yerinə yetirilə bilmir.

Belə halda varikoz qanaxmanın müalicə və profilaktika tədbirləri aşağıdakı strateji hədəflərə yönəlir.

- Qanaxmanı dayandırma və dəstək müalicəsi

- Varikoz qanaxmanın qarşısını alma

- Qanaxmanın təkrarlanmasının qarşısını alma 


\begin{tabular}{|c|}
\hline $\begin{array}{l}\text { Cadval 2. Varikoz qanaxmanın } \\
\text { müalicə prinsipləri və metodları }\end{array}$ \\
Portal hipertenziyanı azaltma \\
(dekompressiya) \\
Konservativ (medikamentoz) \\
Somatostatin (oktreotid) \\
Vazopressin (glipressin) \\
3-adrenoblokatorlar \\
NO sələfləri? \\
Sfinktor büzücüləri \\
Cərrahi yanyollar \\
Endovaskulyar yanyol \\
(QDPKYY) \\
Devaskulyarizasiya \\
Qida borusu \\
transseksiyası \\
Kardio-fundal mexaniki \\
tikiş \\
Sigura əməliyyatı \\
müdaxilə \\
Balon tamponadası \\
Endoskopik liqasiya \\
(həlqə) \\
Endoskopik \\
skleroterapiya \\
Endovaskulyar \\
embolizasiya \\
Varikozlara tikiş \\
(Pasiora) \\
Varikozlara \\
\end{tabular}

\section{Müalicə prinsipləri və metodları}

Varikoz qanaxmanın profilaktika və müalicə tədbirləri 2 prinsip üzərində qurulmuşdur: PH-ı azaltma vo qanaxmant dayandirma (Codvol 2).

PH-1 azaltmaq üçün portal sistemə gələn qanı azaltma və qap1 venasinın dekompressiyası yerinə yetirilir. $\mathrm{Bu}$ tədbirlər əvvəlki bölümdə qeyd edilmişdir.

\section{Qanaxmanı dayandırma üsulları}

Qeyd edildiyi kimi, varikoz qanaxma meydana gəldikdə, ilk tədbir qanaxmanı dayandırmaqdan ibarətdir. Hazırda qanaxmanı dayandırmaq üçün tamponada, medikamentoz, endoskopik, endovaskulyar vo corrahi üsullar tətbiq edilir.

$\mathrm{Bu}$ üsullar mahiyyətco portal təzyiqi ciddi azaltmaq (dekompressiya), portal vena ilə aziqos venası arasında əlaqənin

kəsərək varikoz damarlarda qan axınını kəskin azaltmaqdan (devaskulyarizasiya) və ya varikozlara birbaşa müdaxiladən (varikozların embolizasiyası, tromblaşdırılması, bağlanması) ibarətdir.

\section{Balon tamponadası}

$\mathrm{Bu}$ üsul mahiyyətcə venaların şişirdilmiş balonla sıxılmasından ibarətdir (Şəkil 2). Hansı venaların sıxılmasına görə iki növ balon mövcuddur. Sengstaken-Blakemore zondu iki balondan ibarətdir: 60-500 ml-lik kürəşəkilli mədə balonu zondun 

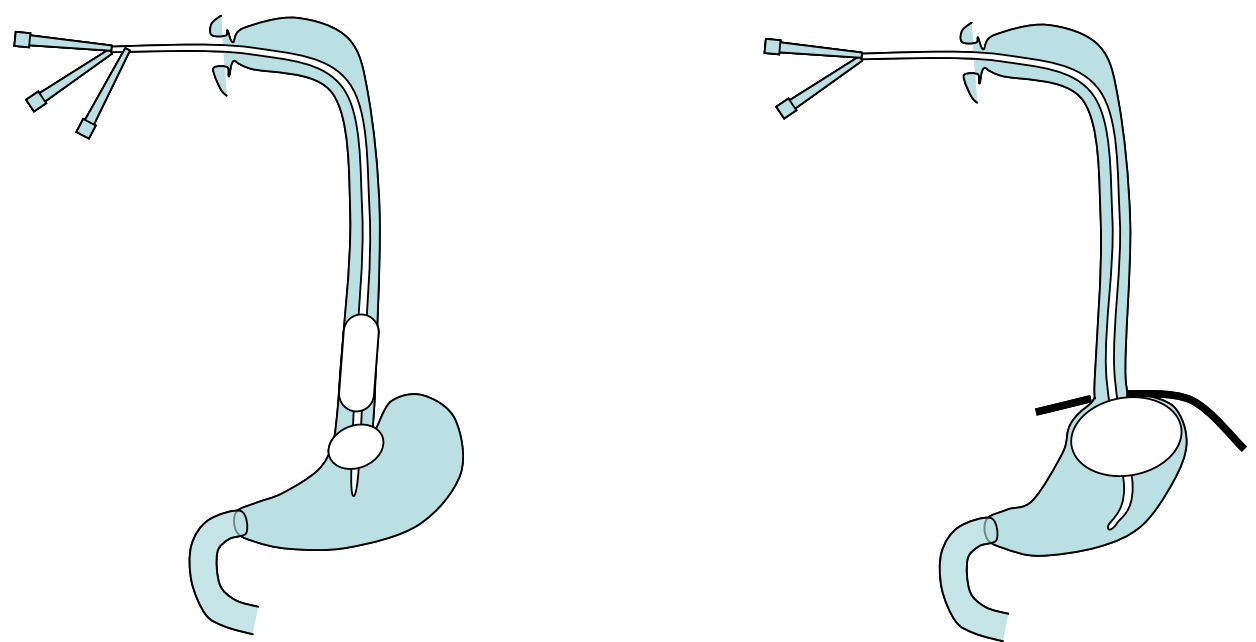

Şəkil 2. Varikoz qanaxmalarda balonla tamponada üsulları

tərpənməməsinə xidmət edir, uzunsov balon 30-40 mm Hg st təzyiqlə şişirdilir, qida borusu varikozlarını sıxaraq qanaxmanı dayandırır. Linton zondu 300-700 ml həcmində balondan təşkil olunubdur. Bu balon mədədə şişirdilir və geriyə dartılaraq mədənin kardiya və dibini diafraqmaya doğru sıxır (300-900 q). Bununla portal sistemlə varikozlar arasında əlaqə kəsilir, yəni kompressiv devaskulyarizasiya yaradilir.

Balon qoyulduqdan sonra, hər yarım saatda bir mədə və qida borusu möhtəviyyatı aspirasiya edilərək həm qanaxmaya nəzarət edilir, həm də aspirasiya ehtimalı azaldılır. Balon 12-24 saatdan sonra boşaldılır və qanaxmaya yenidən nəzarət edilir. Balon boşaldıqdan sonra qanaxma təkrarlaya bildiyi üçün digər üsullara (endoskopik, cərrahi) hazır olmaq lazımdır. Balon tamponadası on tez yerinə yetirilə bilən müvəqqəti hemostaz üsuludur. Lakin bu üsulun bir çox çatışmayan cəhətləri var.

Nəfəs yollarına ağız suyu və burun sekresiyasının aspirasiya ehtimalı yüksəkdir. Ona görə tez-tez (yarım saatdan bir) qida borusunun aspirasiyası və ya intubasiya lazımdır. Zondu 12-24 saatdan çox saxlamaq olmur. Çünki «yataq yaraları» əmələ gələ bilər. Ona görə də, bu üsul müvəqqəti vasitədir. Zondun mədə balonu sürüşərək qida borusuna keçərsə, cırılma törədə bilir ki, bu da ölümcül qanaxma və perforasiyaya səbəb ola bilər.

Bunları nəzərə alaraq balon tamponadası aşağıdakı şərtlər daxilində istifadə edilir. Birincisi, balon tamponadası çox az hallarda - medikamentoz və ya endoskopik üsullar olmadıqda ilk seçim ola bilər. Íkincisi, bu üsullar endoskopik və medikamentoz üsullar 
qanaxmanı dayandırmasa istifadə edilə bilir. Üçüncüsü, tamponadanın müvəqqəti vasitə olduğunu nəzərə alaraq ondan xəstəni stabilləşdirmək və digər üsullara (endoskopik və cərrahi) hazırlıq üçün istifadə edilə bilər. Başqa sözlə, balon tamponadası çətin vaziyyatlardə «heç olmasa» vasitəsi kimi tətbiq edilir.

\section{Medikamentoz müalicələr}

Portal sistemdə təzyiqi aşağı salan dərmanlardan (somatostatin, oktreotid, vazopressin, qlipressin, terlipressin, nitroqliserin) başqa ezofageal varikoz qanaxmanı dayandırmaq üçün digər spesifik preparatlar da istifadə olunur. Xüsusilə ezofaqo-qastral sfinkter tonusunu artırmaq və varikozları «Sıxmaq» üçün pentaqastrin və metklopramidin (serukal) istifadə edilməsi barədə məlumatlar var. Metklopramidi infuziya şəkilində istifadə edildikdə varikoz qanaxmanı azaltdığı bildirilir. Lakin, bu dərmanlar geniş istifadə tapmamışdır və varikoz qanaxmada əsas yeri hələki portal hipotenziya törədən preparatlar tutmaqdadir.

\section{Endoskopik üsullar}

\section{Endoskopik varikoz, liqasiyası (bağlama)}

Bu üsul hazırda varikoz qanaxmanın dayandırılması və profilaktikası üçün ən effektiv və təhlükəsiz üsul hesab edilir. Üsulun mahiyyəti varikoz venanı elastik həlqələrlə dibindən bağlamaqdır (Şəkil 3).. Texniki cəhətdən hemorroidlərin halqalarla bağlanmasına yaxındır. Endoskopun ucuna xüsusi boru keçirilir və bunun üstünə elastik həlqələr yerləşdirilir. Varikoz vena borunun içinə sorulur və bu vəziyyətdə elastik həlqə varikozun dibinə salınır. Həlqə venanı sıxaraq bağlayır. Bir neçə gün sonra varisin distal hissəsi nekrozlaşaraq tökülür, dibindəki yara 2-3 həftədə sağalır. Eyni seansda bir neçə varikozu (adətən 5) bağlamaq mümkündür. Endoskopik liqasiya düzgün yerinə yetirildikdə ağırlaşma törətmir (qida borusu zədələnməsi). Nadir hallarda mukozal xora uzunmüddətə sağalır. Bu üsul hazırda qida borusu varikozu qanaxmasının dayandırılması və profilaktikasında ilk seçimdir. Lakin EVL-n bəzi problemləri də var:

- çox kiçik varikozlarda mümkün olmur

- çox böyük varikozlarda yetərli bağlama alınmır 


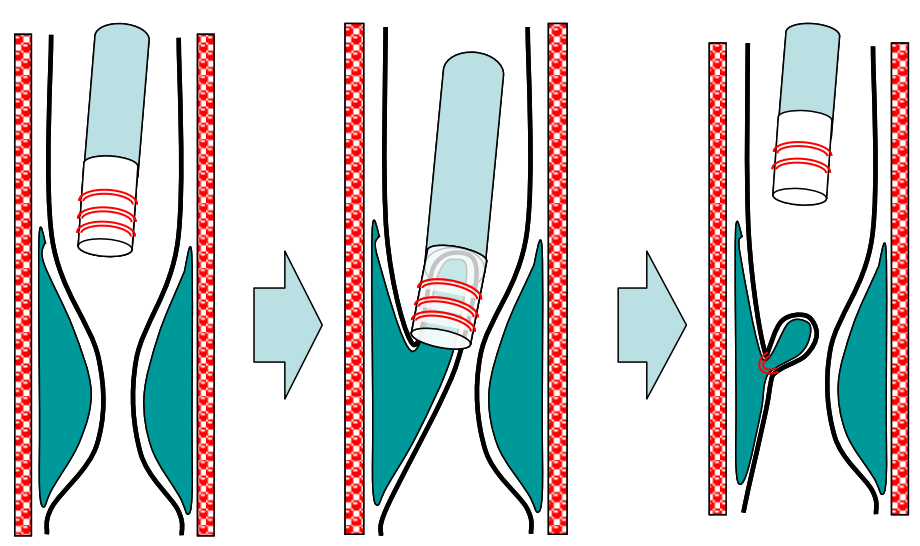

Endoskopik varis liqasiyası

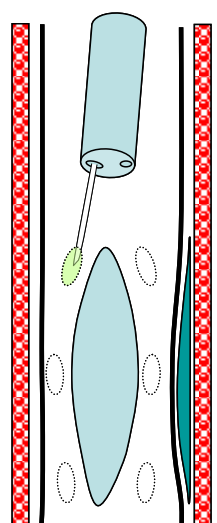

Endoskopik skleroterapiya

\section{Şəkil 3. Varikoz qanaxmanın endoskopik müalicə üsulları}

- $\quad$ əvvəlcə müalicə olunan (skleroterapiya) və aktiv qanayan varikozlarda texniki çətinliklər yaranır

- mədə varikozlarında əks göstərişdir

- qida borusu varikozlarına birbaşa müdaxilələrin digərləri (skleroterapiya, devaskulyarizasiya) kimi EVL-dən sonra da mədə varikozları artır.

\section{Endoskopik skleroterapiya}

$\mathrm{Bu}$ üsulun mahiyyəti ondan ibarətdir ki, varsilərin daxilinə və ya ətrafına sklerozlaşdırıcı maddə yeridilərək tromboz və çapıqlaşma yaradılır (Şəkil 3). . Bu həm qanaxmanı dayandırır, həm də varikozu kiçildir. Sklerozlaşdırıcı maddə kimi alkoqol, etanolamin oleat, tetradesil sulfat istifadə edilir. Son illər sianakrilat vo öküz trombininin istifadəsi haqqında məlumatlar da var. Skleroterapiyanı iltihab söndükdən sonra (3 həftə) bir neçə dəfə təkrarlamaq olar. Skleroterapiya varikoz qanaxmanın dayandırılması və profilaktikası üçün EVL qədər effektiv müalicə sayıla bilər. Lakin bu üsulun bəzi ciddi ağırlaşmaları və çatışmayan cəhətləri var:

- Skleroterapiyadan sonra 50-60\% hallarda qanaxma residivi olur. Ona görə də təkrari seanslara ehtiyac yaranır. 
- Skleroterapiya portal vena trombozuna (30-40\%) səbəb olur ki, bu da gələcəkdə şunt əməliyyatını istisna edir. Ona görə də, az risqli (Child A) xəstələrdə məsləhət deyil.

- Skleroterapiya qastropatiyanı və mədə varikozunu artırır

- Skleroterapiya aziqos vena trombozuna, qida borusu strikturuna, xorasına, mediastinitə, pnevmoniyaya, bakteriemiyaya, allergiya -anaflaksiyaya səbəb ola bilir.

- Mədə varikozlarında hazırki sklerozlaşdırıcı maddələr istifadə edilmir. Son illər sianakrilat və öküz trombininin mədədə xoralaşma vermədiyi bildirilir.

Bunları nəzərə alaraq hazırda skleroterapiya EVL-dən sonrakı seçim sayılır.

\section{Endovaskulyar skleroterapiya}

Ovvəllər endovaskulyar yolla, dəridən-qaraciyərdən, qapı venasından keçərək varikozlara birbaşa skleroz maddə yeridilirdi. Endoskopik üsul hazırda bunu tamamilə əvəz etmişdir.

\section{Corrahi üsullar}

Qanaxmanı dayandırmaq üçün istifadə edilən cərrahi üsulların ilk qrupu portal dekompressiya - porto-kaval yanyol əməliyyatlarıdır ki, bu barədə əvvəlki bölümlərdə məlumat verilmişdir. İkinci qrup əməliyyatlar portal venadan varikoza gələn qan axınının kəsilməsini (devaskulyarizasiya), üçüncü qrup isə, bilavasitə varikoz venaların bağlanmasını (Pasiora əməliyyatı) əhatə edir.

\section{Varikoz venaların bağlanması - Pasiora əmoliyyatı}

Palliativ və təcili edilən bu əməliyyatda qastrotomiya edilərək fundal və ezofageal varikozlara «Z»-şəkilli və ya büzməli tikişlər qoyulur. Bu metod hazırda çox az istifadə edilir. Çünki qida borusu varikozlarında bunu EVL əvəz etmişdir. EVL-ə imkan yoxdursa və ya qastrik varislərdən qanaxma varsa Pasiora üsulu seçilə bilər. 

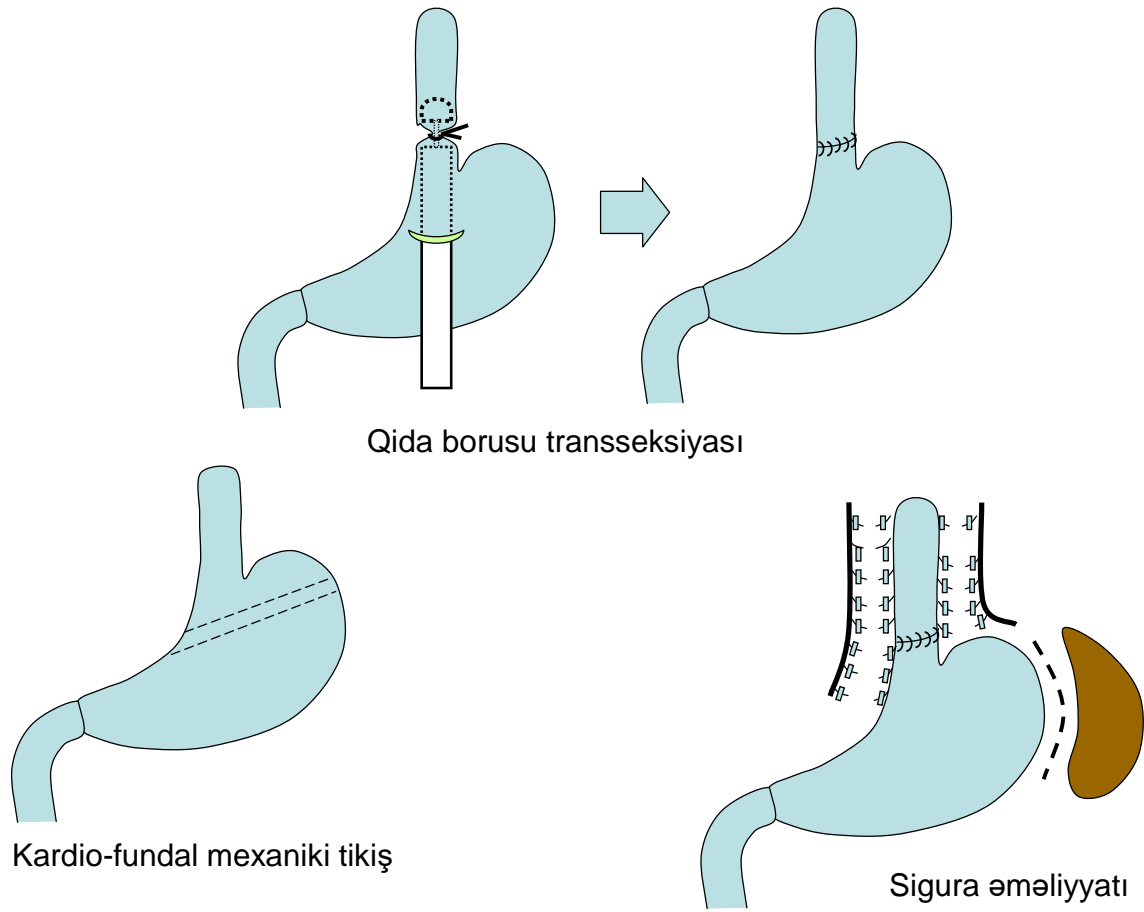

Şəkil 4. Qida borusu varikozlarında devaskulyarizasiya üsulları

\section{Devaskulyarizasiya}

Bu üsulların mahiyyəti ondan ibarətdir ki, qapı venası ilə aziqos sistemi arasında əlaqə kəsilir (Şəkil 4).. Porto-aziqos əlaqəsinin anatomiyasına baxılarsa görünür ki, PH-da qan mədənin kardial və fundal venalarından iki yolla aziqos sisteminə keçir. Birincisi, ezofaqusətrafı kollaterallar, ikincisi isə, selikaltı venoz kələf. Qanaxma məhz selikaltı venalardan baş verir. $\mathrm{Bu}$ anatomik əsaslara dayanaraq əlaqəni kəsmə üsüllarının müxtəlif növləri var.

\section{Qida borusu transseksiyast}

Qida borusunun kəsilib tikilməsi üsulunda qida borusunun abdominal hissəsi kəsilir və yenidən anastomoz edilir (Şəkil 4). Hazırda bu əməliyyat mexaniki tikiş alətləri ilə (28-32 mm) yerinə yetirilir. Bu üsulda portal və aziqoz venası arasındakı selikaltı venoz kələf vasitəsi ilə yaranan və varikoza, qanaxmaya səbəb olan əlaqə kəsilir. $\mathrm{Bu}$ üsul erkən dövrdə qanaxmanı effektiv dayandırır, qaraciyər qanlanmasını pozmur. 
Lakin, paraezofageal venalar saxlandığı üçün təkrari varikoz qanaxma baş verə bilir və anastomoz yetməzliyi ehtimalı var. Bu üsul adətən qisamüddətli qanaxma kontrolu üçün təcili vəziyyətlərdə istifadə edilir.

\section{Kardio-fundal mexaniki tikiş}

Bu üsulda düz tikiş aləti ilə mədənin kardio-fundal hissəsinin ön və arxa divarına ayr1ayrılıqda mexaniki tikişlər qoyulur (Şəkil 4). Bununla da, mədə selikaltı qatından qida borusu selikaltı venalarına gedən yollar bağlanır. $\mathrm{Bu}$ üsul asandır və fundal varikozlarda da faydalıdır. Lakin, əvvəlki üsulda olduğu kimi paraezofageal varislər qaldığı üçün təkrari qanaxma ehtimalı var. Ona görə də təcili vəziyyətlərdə müvəqqəti vasitə kimi istifadə edilir.

\section{Sigura omoliyyatı}

$\mathrm{Bu}$ əməliyyat Yaponiyada və digər şərq ölkələrində geniş yayılmış əməliyyatdır. Sigura əməliyyatında həm qida borusu kəsilib tikilir, həm qida borusu ətrafındakı abdominal və döşdaxili venoz damarlar bağlanır, həm də dalaq çıxarılır (Şəkil 4). Nəticədə həm selikaltı həm, də paraezofageal porto-aziqos əlaqəsi kəsilir. Bu nöqteyinəzərdən Sigura əməliyyatı on radikal devaskulyarizasiya hesab edilir və praktik təcrübədə də özünü doğruldur. Qanaxmanı dayandırma və profilaktika nöqteyinəzərdən Sigura əməliyyatı DSRYY əməliyyatı ilə müqayisə oluna bilər. Bu üsulun digər bir müsbət cəhəti qaraciyər qan axınını pozmamasıdır. Lakin bu üsulda qarın və döş boşluğunu açmaq gərəkir, digər tərəfdən mədə varikozlarının qarşısı alınmır və təcrübə gərəkdirir.

Beləliklə, devaskulyarizasiya əməliyyatları ezofageal varikozlardan qanaxmanı dayandırmaq üçün effektiv üsuldurlar və qaraciyər qangəlimini pozmurlar. Bu üsullar arasında Sigura əməliyyatı ən radikaldır və qanaxmanı dayandırmaqla yanaşı təkrari varikozun və qanaxmanın da qarşısını alır. Lakin bunlar qastrik varikozların qarşısını ala bilmədikləri üçün DSRYY-dan geri qalırlar. 
Portal hipertenziyanı azaltma və varikoz qanaxmanı dayandırma üsullarının ümumi xarakteristikası

Yuxarıda da qeyd edildiyi kimi, PH və varikoz qanaxmanın müalicəsi üçün mövcud oaln cərrahi, endoskopik, endovaskulyar və medikamentoz tədbirləri prinsipial olaraq üç qrupda cəmləşdirmək olar: portal təzyiqi azaltma - dekompressiya, varikozlarda qan axınını kəsmə - devaskulyarizasiya, varikozlara birbaşa müdaxilə. Asan yadda qalması üçün buna “DDB” (dekompressiya, devaskulyarizasiya, birbaşa) demək olar. Mövcud tədbirləri qanaxmanı dayandırmaya, letallığa və yan təsirlərinə görə müqayisə etdikdə aşağıdakı nəticələrə gəlmək olar (Codvəl 3).

Qanaxmanı dayandırma nöqteyi-nəzərdən bu tədbirlər arasında ciddi fərqlər olmadığı bildirilir. Lakin, qanaxmanı hansı müddətə dayandırma və təkrari qanaxmaların qarşısını almağa görə bu tədbirlər arasında fərqli cəhətlər ortaya çıxır.

Balon tamponadası qanaxmanı müvəqqəti dayandırır, ona görə də əsas müalicə tədbirlərinə qədər hazırlıq vasitəsi kimi istifadə edilir.

Endoskopik tədbirlər arasında $E V L$ həm effektiv, həm də, yan təsiri az olan üsuldur. Lakin, qanaxmanın uzunmüddətli nəzarəti üçün təkrari (3-4 həftə aralıqla) seanslara ehtiyac vardir.

Endovaskulyar tədbir olan $Q D P K Y Y$ qanaxmanın bir neçə ay qarşısını ala bilir (tromboz ehtimalı yüksək olduğu üçün). Ona görə də bu üsul transplantasiyaya hazırlıq dövründəki qanaxmalarda istifadə edilir.

Medikamentoz tadbirlarin qanaxmanı dayandırmaq (oktreotit, vazopressin və analoqları) ehtimalı (70-80\%) endoskopik və cərrahi üsullardan müəyyən dərəcədə geri qalır. İlkin və ikincili profilaktika üçün nəzərdə tutulan $\beta$-blokatorlar digər üsullarla (endoskopik) birlikdə istifadə oluna bilər. 
Cərrahi tadbirlərə gəldikdə, həm dekompressiv (YY), həm devaskulyarizasiya, (Siqura, transseksiya, tikiş və s.), həm də birbaşa əməliyyatlar (Pasiora) qanaxmanı effektiv şəkildə dayandırır. Təkrari qanaxmanı önləmək baxımından PKYY-lar devaskulyarizasiyalardan daha effektivdir. Çünki devaskulyarizasiya əməliyyatları porto-aziqos əlaqəsini kəsərək qanaxmanı dayandırır, əsas patogenetik amil olan $\mathrm{PH}$ isə nəinki azalır, hətta artır. $\mathrm{Bu}$ da devaskulyarizasiya əməliyyatlarının əsas mənfi cəhəti sayılan qastrik varisləri artırmasına səbəb olur. Dekompressiv əməliyyatların isə, əsas mənfi cəhəti Qc disfunksiyasını və ensefalopatiyanı artırmasıdır. Devaskulyarizasiya əməliyyatları arasında qanaxmanı dayandırma baxımından on radikalı Sigura əməliyyatıdır, ən asanı isə transseksiyadır. PKYY əməliyyatları arasında isə, qastroezofageal qanaxmanı dayandırma və ensefalopatiya baxımından ən səmərəlisi selektiv yanyol - xüsusən DSRYY hesab edilir.

Bu müqayisəli analizdən belə nəticəyə gəlmək olar ki, əsas səbəbi aradan qaldırmaq mümkün olmadıqda PH və varikoz qanaxmanın effektiv müalicəsi böyük problem təşkil edir və cərrah çoxsaylı üsullar arasında seçim etmək məcburiyyətində qalır. $B u$ prosesda asas prinsip üsulun müsbat va manfi cahatlarina va xastanin vaziyyatina asaslanan seçimdir.

Tacili vəiyyatlardə qanaxmanı dayandırmaq üçün medikamentoz və endoskopik üsullar istifadə edilməsi məsləhətdir. Bunlar effektsiz olarsa, tacili olaraq bəsit cərrahi üsullar (yan-yan PKYY, transseksiya, Pasiora əməliyyatları) və ya QDPKYY yerinə yetirilir.

Qanaxmanı uzunmüddatli dayandırmaq üçün ən effektiv üsul PKYY-dır. Xüsusən, DSRYY bu məqsədlə ən uyğundur. DSRYY imkansız olarsa (splenik vena trombozu, splenektomiya, Child C sirroz, assit) devaskulyarizasiya və ya təkrari endoskopik müalicələr tövsiyə olunur. Qc transplantasiyasına namizədlərdə endovaskulyar müdaxilə- QDPKYY istifadə oluna bilər. 
Cədvəl 3. Varikoz qanaxmada istifadə olunan müalicələrin xüsusiyyətləri

\begin{tabular}{|c|c|c|c|c|}
\hline Üsul & Mexanizmi & Effektivliyi & Monfi cəhəti & Göstoriş \\
\hline $\begin{array}{l}\text { Balon tamponadası } \\
\text { (Sengstaken-Blakemore, } \\
\text { Linton) }\end{array}$ & $\begin{array}{l}\text { Ezofaqus varikozlarını } \\
\text { (Blekmor) və ya mədə } \\
\text { dibini diafraqmaya } \\
\text { (Linton) mexaniki } \\
\text { s1xma }\end{array}$ & $\begin{array}{l}\text { Qanaxmanı müvəqqəti } \\
\text { dayandırır }\end{array}$ & $\begin{array}{l}\text { Müvəqqətidir } \\
\text { Aspirasiya } \\
\text { QB yırtılması }\end{array}$ & $\begin{array}{l}\text { Medikamentoz və } \\
\text { endoskopik tədbirlər } \\
\text { yetərsizdirsə müvvəqqəti } \\
\text { olaraq istifadə edilə bilər }\end{array}$ \\
\hline $\begin{array}{l}\text { Endoskopik } \\
\text { skleroterapiya }\end{array}$ & $\begin{array}{l}\text { Varikozlara və ətrafina } \\
\text { skleroz maddə } \\
\text { yeridilərək çapıqlaşma } \\
\text { və tromboz törətmə }\end{array}$ & $\begin{array}{l}\text { Qanaxmanı dayandırır } \\
\text { və qarşısını alır }\end{array}$ & $\begin{array}{l}\text { QB xoraları } \\
\text { Portal vena trombozu } \\
\text { Mediastinit, pnevmoniya } \\
\text { QB strikturas1 } \\
\text { Mədə varislərini artırır }\end{array}$ & $\begin{array}{l}\text { EVL mümükün deyilsə } \\
\text { təcili vəziyyətlərdə } \\
\text { qanaxmanı dayandırmaq } \\
\text { üçün ən faydaı üsuldur }\end{array}$ \\
\hline $\begin{array}{l}\text { Endoskopik həlqələmə } \\
\text { (endoskopik varis } \\
\text { liqasiyası - EVL) }\end{array}$ & $\begin{array}{l}\text { Varisləri elastik halqa } \\
\text { ilə bağlama }\end{array}$ & $\begin{array}{l}\text { Qanaxmanı dayandırır } \\
\text { və qarşısını alır }\end{array}$ & $\begin{array}{l}\text { QB xoraları } \\
\text { Mədə varislərini artırır }\end{array}$ & $\begin{array}{l}\text { QB varikoz } \\
\text { qanaxmasının } \\
\text { profilaktika və müalicəsi } \\
\text { üçün ilk seçimdir }\end{array}$ \\
\hline Somatostatin vo oktreotid & $\begin{array}{l}\text { Splanxik sistemdə } \\
\text { arterial } \\
\text { vazokonstruksiya } \\
\text { törədərək portal təzyiqi } \\
\text { azaldır }\end{array}$ & Qanaxmanı dayandırır & $\begin{array}{l}\text { Q1samüddətli effekt } \\
\text { İmmunosupressiya }\end{array}$ & $\begin{array}{l}\text { Endoskopik müayinə və } \\
\text { müalicəyə qədər } \\
\text { qanaxmanı azaltmaq } \\
\text { üçün istifadə edilir }\end{array}$ \\
\hline
\end{tabular}




\begin{tabular}{|c|c|c|c|c|}
\hline Üsul & Mexanizmi & Effektivliyi & Mənfi cəhəti & Göstəriş \\
\hline $\begin{array}{l}\text { Vazopressin vo } \\
\text { analoqları (qlipressin) }\end{array}$ & $\begin{array}{l}\text { Splanxik sistemdə } \\
\text { arterial } \\
\text { vazokonstruksiya } \\
\text { törədərək portal təzyiqi } \\
\text { azaldır }\end{array}$ & Qanaxmanı dayandırır & Ürək damarlarında spazm & $\begin{array}{l}\text { Endoskopik müayinə və } \\
\text { müalicəyə qədər } \\
\text { qanaxmanı azaltmaq } \\
\text { üçün istifadə edilir }\end{array}$ \\
\hline$\beta$-adrenoblokatorlar & $\begin{array}{l}\text { Splanxik sistemdə } \\
\text { arterial } \\
\text { vazokonstruksiya } \\
\text { törədərək portal təzyiqi } \\
\text { azaldır }\end{array}$ & $\begin{array}{l}\text { Kəskin qanaxmada } \\
\text { effektiv deyil }\end{array}$ & $\begin{array}{l}\text { Hipotoniya } \\
\text { Ensefalopatiyada artma }\end{array}$ & $\begin{array}{l}\text { Qanaxmanın } \\
\text { profilaktikası üçün } \\
\text { istifadə edilir }\end{array}$ \\
\hline $\begin{array}{l}\text { Total portokaval yanyol: } \\
\text { yan-yan } \\
\text { uc-yan } \\
\text { proksimal splenorenal } \\
\text { mezo-kaval }\end{array}$ & $\begin{array}{l}\text { Portal axına } \\
\text { müqaviməti və PH-1 } \\
\text { azaldır }\end{array}$ & $\begin{array}{l}\text { Qanaxmanı ən effektiv } \\
\text { azaldan üsuldur }\end{array}$ & $\begin{array}{l}\text { Oməliyyat riski } \\
\text { Ensefalopatiya (40\%) } \\
\text { Qc disfunksiyası }\end{array}$ & $\begin{array}{l}\text { DSRYY mümkün } \\
\text { deyilsə (assit, } \\
\text { splenektomiya) seçilə } \\
\text { bilər }\end{array}$ \\
\hline $\begin{array}{l}\text { Hissəvi portokaval } \\
\text { yanyol: } \\
\text { "H"-tipli mezo-kaval, } \\
\text { splenorenal }\end{array}$ & $\begin{array}{l}\text { Portal axına } \\
\text { müqaviməti və PH-1 } \\
\text { azaldır }\end{array}$ & $\begin{array}{l}\text { Qanaxmanı effektiv } \\
\text { azaldır }\end{array}$ & $\begin{array}{l}\text { Tromboz və } \\
\text { ensefalopatiya ehtimalı } \\
\text { yüksəkdir }\end{array}$ & $\begin{array}{l}\text { DSRYY mümkün } \\
\text { deyilsə seçilə bilər }\end{array}$ \\
\hline $\begin{array}{l}\text { Selektiv yanyol: } \\
\text { distal-splenorenal } \\
\text { qastrorenal }\end{array}$ & $\begin{array}{l}\text { Qastro-splenik venoz } \\
\text { hovuz mezenterik } \\
\text { hovuzdan ayrilır vo } \\
\text { dekompressiya edilir }\end{array}$ & $\begin{array}{l}\text { Həm QB, həm də mədə } \\
\text { varkoz qanaxmalarını } \\
\text { effektiv azaldır }\end{array}$ & $\begin{array}{l}\text { Assiti artıra bilir } \\
\text { Zəif ensefalopatiya (7\%) }\end{array}$ & $\begin{array}{l}\text { Qanaxmanın (həm QB, } \\
\text { həm də mədə } \\
\text { varikozlarında) } \\
\text { uzunmüddətli }\end{array}$ \\
\hline
\end{tabular}




\begin{tabular}{|c|c|c|c|c|}
\hline Üsul & Mexanizmi & Effektivlivi & Mənfi cəhəti & Göstəris \\
\hline & & & & $\begin{array}{l}\text { dayandırılması üçün ən } \\
\text { effektiv üsuldur }\end{array}$ \\
\hline $\begin{array}{l}\text { Qaraciyərdaxili } \\
\text { portokaval yanyol }\end{array}$ & $\begin{array}{l}\text { Qc və qap1 venaları } \\
\text { arasında Qc-daxili } \\
\text { stend yerləşdirilir }\end{array}$ & Qanaxmanı azaldır & $\begin{array}{l}\text { Erkon tromboz } \\
\text { Ensefalopatiya }\end{array}$ & $\begin{array}{l}\text { Qc transplantasiyası } \\
\text { gözləyən xəstələrdə } \\
\text { qanaxmanı müvəəqqəti } \\
\text { dayandırmaq üçün }\end{array}$ \\
\hline $\begin{array}{c}\text { Devaskulyarizasiya } \\
\text { QB transseksiyası } \\
\text { Mədə tikişləri } \\
\text { Sigura əməliyyatı }\end{array}$ & $\begin{array}{l}\text { Qastroezofaqeal } \\
\text { kollaterallar və } \\
\text { varikozlar bağlanır və } \\
\text { ya bağlanıb kəsilir }\end{array}$ & $\begin{array}{l}\text { QB varikoz } \\
\text { qanaxmalarını effektiv } \\
\text { dayandırır }\end{array}$ & Mədə varislərini artırır & $\begin{array}{l}\text { Təcili vəziyyətlərdə } \\
\text { transseksiya və ya tikmə, } \\
\text { planll vəziyytlərdə isə } \\
\text { Siqura }\end{array}$ \\
\hline
\end{tabular}




\section{QIDA BORUSU VARİKOZ QANAXMASINDA MÜALICC TAKTIKKASİ}

\section{Qanaxmanın ilkin profilaktikası}

Varikozun təbii gedişinə nəzər salınarsa görünür ki, varikoz tapıldıqdan sonra 2 il ərzində qanaxma yoxdursa onun baş vermə ehtimalı çox aşağıdır. Lakin, qanaxma riski yüksək olan hallarda onun profilaktikasına ehtiyac yaranır. Xüsusən, III-IV dərəcəli, incə divarlı (qırmızı nöqtə, tumurcuqlu) varikozlar, yüksək portal təzyiq, Child C hallarında qanaxma riski yüksəkdir və profilaktik tədbirlər həyata keçirilməlidir. Belə xəstələrdə $\beta$-adrenoblokatorlar və endoskopik müalicələr tövsiyə edilir. EVL ən çox tövsiyə olunan üsuldur, təkbaşına və ya $\beta$-adrenoblokatorlarla birlikdə istifadə edilə bilər. Az riskli xəstələrdə isə, nəzarətdə saxlama və ya $\beta$-blokator istifadəsi tövsiyə olunur.

\section{Kəskin qanaxmanın dayandırılması}

Kəskin varikoz qanaxması olan xəstələr təcili müdaxilə gərəkdirən haldır. Xəstə təcili olaraq xəstəxanya - reanimasiya və ya əməliyyatxanaya yerləşdirilir. Xəstədə təcili olaraq ilkin tədbirlər - hemodinamika bərpası, endoskopik müayinə və qanaxmanı dayandırmaq gərəkir (Codval 4 vo Şəkil 5).

Hemodinamikanın bərpası üçün kolloid, kristalloid və göstərişə görə qan köçürülməlidir.

Endoskopik müayinə və müalicəyə qədər medikamentoz müalicə başlanıla bilər. $\mathrm{Bu}$ məqsədlə somatostatin və analoqları və ya vazopressin və analoqları istifadə edilir. Təcili endoskopik müayinə ilə qanaxmanın səbəbi, davam edib-etməməsi, mədə varikozunun olub-olmaması dəqiqləşdirilir. Eyni vaxtda endoskopik müalicə yerinə yetirilir. İlk seçim EVL-dir. EVL mümkün olmazsa skleroterapiya edilir.

$\mathrm{Bu}$ xəstələrdə ensefalopatiyanın profilaktikası üçün mədə (mədəni zondla yuma) və bağırsaqlardakı qanı təmizləmək lazımdır (oral laksativ - laktuloza, laktibiol, Nafosfat və imalə). Hemostatik preparatlar (vikasol, antifibrinolitiklər) koaqulyasiya pozulmaları olan xəstələrdə istifadə edilir. 
1. Xəstə təcili olaraq reanimasiya şöbəsinə yatırılır, cərrah, reanimatoloq və endoskopist briqadası tərəfindən nəzarətə alınır.

2. Hava yolu yoxlanılır və keçiriciliyi təmin edilir. Aramsız qanaxmalarda və ensefalopatik xəstələrdə təcili intubasiya edilir.

3. Hemodinamika qiymətləndirilir vo hipovolemiya varsa (taxikardiya, hipotenziya, ortostatik kollaps) infuziyaya başlanılır

4. Damar yolu açılır, təhlillər alınır (Hemoqram, PTZ, APTZ, qanaxma, laxtalanma zamanı, qlükoza, ALT, AST, sidik cövhəri, kreatinin, albumin, bilrubin, elektrolitlər, HBsAg, Anti-HCV).

5. Şokda olan xəstələyə Ringer - Laktat bolus şəklində 1000 ml verilir və kolloid infuziyasına (plazma, albumin, jelatin, dekstran) başlanılır.

6. Sidik kateteri qoyulur.

7. Sandostatin $(250 \mathrm{mkq}$ ilk doz, $250 \mathrm{mkq} / \mathrm{saat}$ infuziya), oktreotid (50 mkq ilk doz, 50mkq/saat infuziya) və ya terlipressin ( $2 \mathrm{mq}$ hər 4 saatda) müalicəsinə başlanır.

8. Antisekretor ranitidin (Zantak $50 \mathrm{mq} \times 3$ ) vo ya rabeprazol infuziyası edilir..

9. Qan bankasından eritrositar kütlə, plazma tədarük edilir.

10. $\mathrm{Hb}<10 \mathrm{q} / \mathrm{dL}$ və ya $\mathrm{Ht}<30 \%$ olan xəstələrə hemotransfuziya başladılır.

11. TDP koaqulopatiyasi varsa $($ INR $>1,5)$ və qan transfuziyası alanlarda (hər 2 vahid qana 1 vahid plazma)

12. Vikasol $(\mathbf{1 0} \mathbf{~ m q})$ təyin edilir. Fibrinogeni az olanlarda $(<200 \mathrm{mq})$ kriopresitat verilir. Trombositopeniya $\left(<50 \quad x \quad 10^{9} / \mathrm{L}\right)$ olarsa trombosit kütləsi köçürülür

13. Şəkər, elektrolit tənzimlənir. Hipoqlikemiya və hpokalemiya ensefalopatiyanı dərinləşdirir.

14. Qarın boşluğu USM və portal dopler edilir.

15. Xəstə hərtərəfli monitorinq edilir (hemodinamika, tənəffüs, sidik ifrazı, NQZ-dan ifrazat, melena, $\mathrm{Hb}, \mathrm{Ht}$, huş və digər)

16. Hemodinamika stabilləşmişsə təcili endoskopik müayinə və müalicə edilir.

17. Xəstə stabilləşmirsə və qanaxma artaraq davam edirsə Blekmor zondu qoyulur vo intubasiya edilir. Blekmor zonduna baxmayaraq stabilləşmə yoxdursa təcili angioqrafiya və ya əməliyyat edilir. Oməliyyat vaxtı endoskopik müayinə aparılması vacibdir. 


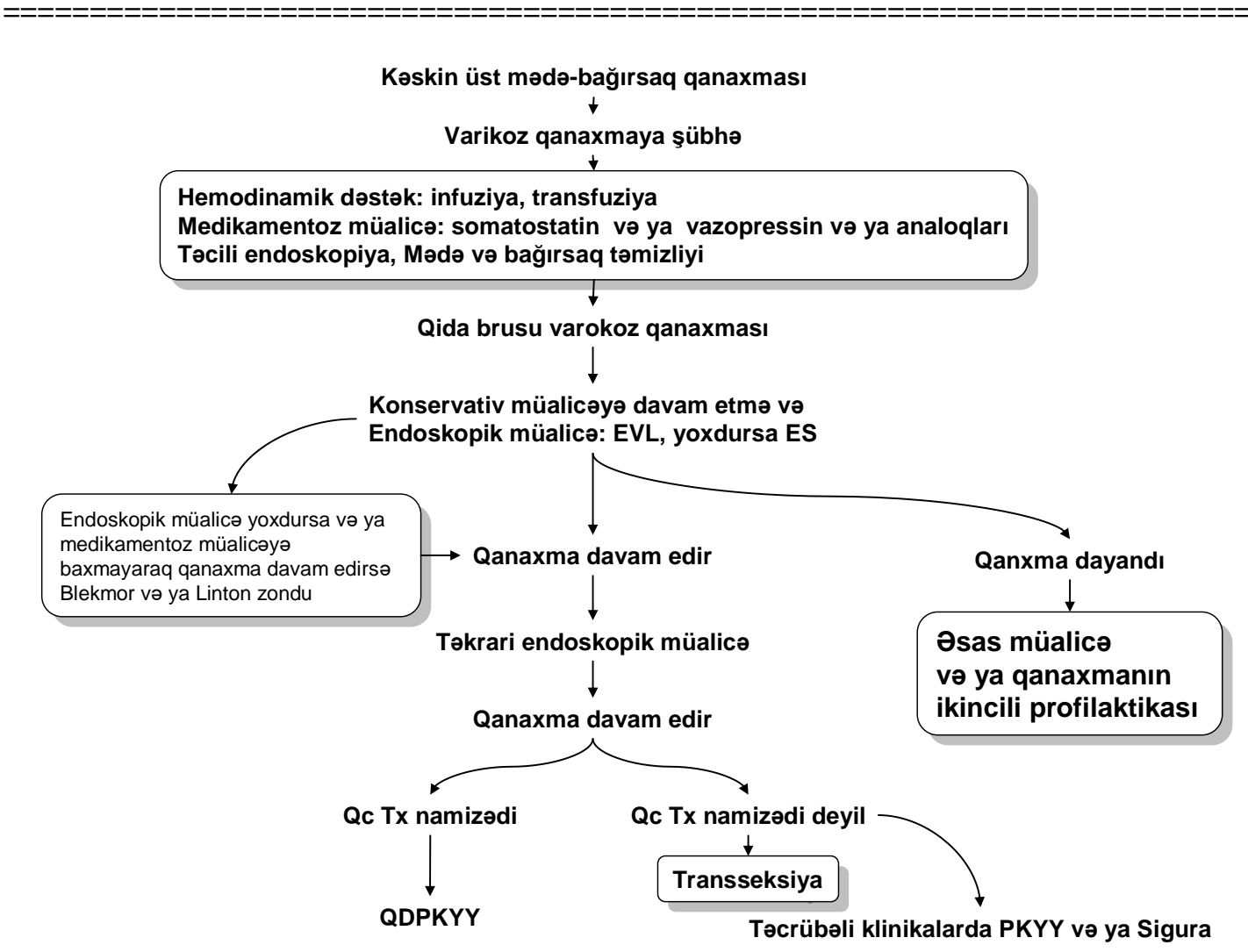

\section{Şəkil 5. Varikoz qanaxmada müalicə taktikası (ilkin tədbirlər)}

Medikamentoz və endoskopik müalicələr gecikirsə və ya yoxdursa, qanaxma isə davam edirsə, Blekmor zondu istifadə edilə bilər. Blekmor zondu endoskopik müalicəyə tabe olmayan qanaxmalarda da istifadə edilir.

Endoskopik və/və ya medikamentoz tədbirlərdən sonra iki nəticə ortaya çıxa bilər. Birincisi, qanaxmanın dayanması ki, bu təxminən xəstələrin $80 \%$ rastlanır. $\mathrm{Bu}$ xəstələrdə qanaxmanın uzunmüddətli profilaktikası üçün tədbirlər həyata keçirilir. İkincisi, qanaxmanın davam etməsi və ya tezliklə (bir neçə gün sonra) təkrarlanması. Bu xəstələrdə ən çox tövsiyə olunan yol endoskopik müalicənin təkrarlanmasıdır. Đgər təkrari endoskopik müalicə imkansızdırsa və ya effektsiz olarsa təcili əməliyyat gərəkir. Belə vəziyyətdəki xəstələrin ümumi vəziyyətinin ağır olduğunu, qaraciyərin funksional vəziyyətini dəqiqləşdirməyin çətin olduğunu nəzərə alaraq, asan və effektiv üsul seçilməlidir. Davam edən varis qanaxmasını dayandırmaq üçün tövsiyə olunan təcili əməliyyat qida borusunun staplerlə transseksiyasıdır. $\mathrm{Bu}$ alət yoxdursa və ya xəstədə mədə varikoz qanaxması da varsa kardio-fundal mexaniki tikiş və ya Pasiora əməliyyatı yerinə yetirilə bilər. Xəstənin vəziyyəti çox ağır olarsa və ya transplantasiya namizədidirsə belə hallarda QDPKYY istifadə edilə bilər. 


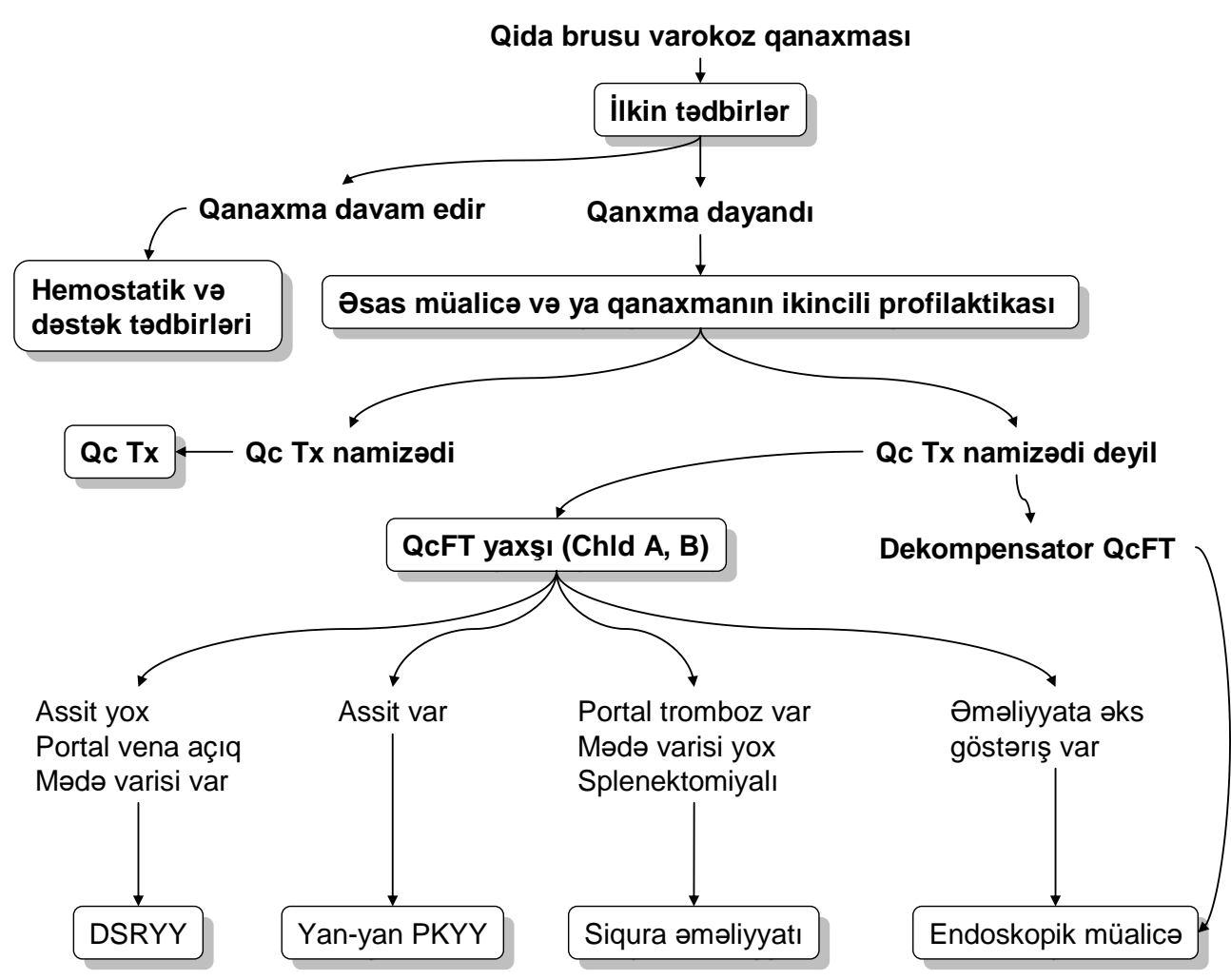

Şəkil 6. Varikoz qanaxmada müalicə taktikası (əsas müalicə və ya ikincili profilaktika)

\section{Qanaxmanın təkrarlanmasının profilaktikası (uzunmüddətli nəzarət)}

Qeyd edildiyi kimi, medikamentoz və endoskopik müalicələr əksər hallarda (80\%) varikoz qanaxmanı dayandırır. Lakin bu xəstələrin əksəriyyətində (60-70\%) qanaxma bir il ərzində təkrarlaya bilir. Ona görə də, ikincili profilaktika üçün qanaxmaya effektiv və uzunmüddətli nəzarət üsulu seçilməlidir.

Müalicə üsulunu seçərkən üsulun mənfi və müsbət cəhətləri və xəstənin vəziyyəti ilə əlaqəli amilləri, xüsusən Qc-in funksional rezervini, assit, ensefalopatiya, mədə varikozu, yanaşı xəstəliyi, səbəbi), Qc Tx imkanı və portal vena açıqlığını nəzərə almaq lazımdır (Şəkil 6).

İlk növbədə xəstəyə Qc Tx göstərişi və mümkünlüyü təyin olunur. Xəstəyə Qc Tx göstərişdirsə (dekompensasiya sirroz) və bü mümkündürsə, ciddi nəzarətlə transplantasiyaya hazırlanır. $\mathrm{Bu}$ xəstələrdə $\mathrm{Tx}-ə$ qədər qanaxma təkrarlanarsa QDPKYY istifadə edilə bilər. 
Tx məsləhət və ya mümkün olmayan xəstələrdə Qc-in funksional rezervi və digər amillər nəzərə alınır. Qc funksiyası qorunan xəstələrdə (Child A, B xəstələr) üç yoldan biri seçilə bilər: endoskopik nəzarət, PKYY və devaskularizasiya əməliyyatı. Bunlardan ən çox tövsiyə olunanı yanyol əməliyyatıdır və DSRYY ilk seçənəkdir. DSRYY-ə əks göstəriş varsa (splenik vena trombozu, splenektomiya, refrakter assit) Sigura əməliyyatı və ya hissəvi

PKYY edilə bilər.

Bəzi müəlliflər endoskopik nəzarət və vaxtaşırı müalicələri ilk planda tuturlar və bunlar mümkün olmadıqda cərrahi üsulları tövsiyə edirlər. Lakin xəstədə mədə varisləri də varsa yanyol əməliyyatları mütləq olaraq ilk planda durur. Endoskopik müalicə olunan xəstələrdə $\beta$-adrenoblokatorlar da istifadə oluna bilər.

Qc Tx mümkün olmayan və Qc dekomensasiyası olan xəstələrdə cərrahi üsullar tövsiyə edilmir. Bu xəstələrdə endoskopik nəzarət və müalicə və ya QDPKYY istifadə tövsiyə olunur.

\section{MӘDӘ VARİKOZUNDAN QANAXMA}

Portal hipertenziya mədədə iki xarakterik patologiya törədir: mədə varikozları və hipertenziv qastropatiya. PH-da əksər hallarda az və ya çox dərəcədə mövcud olan mədə varikozları ezofaqus varikozları ilə birlikdə rast gələ bilir. Lakin, ezofaqus varikozu olan xəstələrdə mədə varikozu olmaya da bilər. Bu hallar ezofaqus kollaterallarının daha yaxşı işlədiyini göstərir. Xəstədə yalnız mədə varikozunun olması daha çox iki vaziyyət üçün xarakterikdir.

Birincisi, dalaq venası trombozu və ya böyük dalaqla əlaqədar vəziyyət ki, buna «soltərəfli» (selektiv) PH-da deyilir. Bu halda venoz drenajı təmin etmək üçün mədənin kiçik venaları əsas kollateral rolu oynayır və mədənin selikaltı venoz sistemini yükləyərək varikoza səbəb olur. Íkinci vəziyyət isə, endoskopik liqasiya, skleroterapiya və ya devaskulyarizasiya əməliyyatlarından sonra porto-aziqos əlaqəsinin kəsilməsi ilə əlaqədar mədə varikozlarının artması və ya əmələ gəlməsidir. Qida borusu varikozu ilə müqayisədə mədə varikozunun qanaxma ehtimalı daha yüksək, qanaxmasını dayandırmaq isə daha çətindir. Diaqnozu endoskopik müayinə 
ilə dəqiqləşdirmək mümkündür. Mədə varikozu QB varikozu ilə birlikdə və ya təkbaşına qanaya bilər.

Mədə varikozu qanaxmasının müalicəsi bəzi cəhətlərinə görə QB qanaxmasına yaxın olsa da, bəzi prinsipial fərqləri də var. Mədə varikoz qanaxmasında müalicə taktikası ümumi plana uyğun şəkildə aparılır: ilkin tədbirlər və asas-həlledici müalicə.

Qanaxması olan xəstədə təcili ilkin tədbirlərlə xəstədə hemodinamika stabilləşdirilir, diaqnoz dəqiqlaşdirilir və qanaxma dayandırılmă̆a çalışılır: infuziyon-transfuziyon terapiya, təcili endoskopiya və $\mathrm{PH}-1$ azaldıcı medikamentoz müalicə. Mədə varikozlarından qanaxma dəqiqləşərsə qanaxma əsasən konservativ yolla dayandırılmağa çalışılır. Qida borusu varikoz qanaxmasından fərqli olaraq mədə varikozlarında mövcud vasitələrlə endoskopik skleroterapiya və varis liqasiyası etmək mümkün deyil. Hazırki endoskopik müalicələr nəticəsində yaranan nekroz və ya skleroz bölgəsi mədə şirəsi ilə «yeyilərək» xora və ağırlaşmalarını törədir. Son illər bu məqsədlə təklif edilən yeni endoskopik vasitələr (sianakrilat, öküz trombini) hələlik sinaq səviyyəsindədir.

Konservativ tədbirlər qanaxmanı dayandırmazsa həyat qurtarışı tədbir kimi təcili əməliyyat edilir. Әməliyyat vaxtı hemostazı təmin etmək üçün qastrotomiya edərək varislərə tikiş qoymaq olar (Pasiora əməliyyatı), kardio-fundal tikişlərlə varisləri tikmək mümkündür və ya fundusektomiya əməliyyatı edilə bilər Transplantasiya namizədlərində QDPKYY istifadə edilə bilər. Xəstədə «soltərəfli» $\mathrm{PH}$ varsa (dalaq venası trombozu, böyük dalaq) təcili splenektomiya da faydalı ola bilər.

Qanaxması dayanan xəstələrdə təkrari qanaxmanın profilaktikası üçün uyğun həlledici müalicə həyata keçirilməlidir. Qida borusu varikozundan fərqli olaraq mədə varikozunda devakuskulyarizasiya və qida borusu varikozunun endoskopik müalicələri əks göstəriş sayılır. «Soltərəfli» PH-da ən effektiv müalicə splenektomiyadır. Qc Tx namizədi olmayan, Qc funksiyası qorunan xəstələrdə şunt əməliyyatı, xüsusən DSRYY ilk seçimdir. Qc funksiyası dekompensasiya vəziyyətində olan xəstələrdə isə, QDPKYY və ya medikamentoz müalicə tövsiyə olunur.

\section{HEMORROİDAL VARİKOZLARDAN QANAXMA}


PH-da hemorroidal varikozlar qida borusu varikozundan sonra ən çox rast gələn varikozdur. Oksər hallarda asimptomatik gedir. Lakin tromboz və qanaxma da törədə bilər. $\mathrm{Bu}$ xəstələrdə hemorroid varikozları adətən qanaxma törətdikdə ciddi kliniki müdaxilə tələb edir. Oksər hallarda hemorroidal qanaxma konservativ tədbirlərlə (hemorroidal məlhəm, nəcis yumşaldılması) dayanır. Lakin davam edən qanaxmalarda cərrahi müdaxilə gərəkir. Adi hemorroidlərdən fərqli olaraq PH-da klassik hemorroidektomiya tövsiyə olunmur. Çünki ağır qanaxmalar başlaya bilər. Ona görə də, daha konservativ cərrahi müdaxilə seçilməlidir. Varis liqasiyası, skleroterapiya, lazer və ya infraqırmızı koaqulyasiya ən çox tövsiyə edilən müdaxilələrdir.

\section{Osas ədəbiyyat}

1. Ağayev B.A. Corrahi Xəstวliklar. Bakı 2001

2. Blumgart LH. Surgery of the Liver, Biliary tract and Pancreas. 4th ed. 2006

3. Cuschieri SA. Disorders of the liver. Module 10, p 321-374. in Cuschieri SA, Steel RJ, Moossa AR. Essentiale Surgical practice.. $4^{\text {th }}$ ed. 2002

4. Feldman M, Friedman LS, Sleisenger MH. Sleisenger and Fordtran's Gastrointestinal and Liver diseases. $7^{\text {th }}$ ed. Vol II, 2002.

5. Modern Surgical Care. 2 ed. Vol I, 1998

6. Oxford textbook of Surgery V.1,2004

7. Rob and Smith's Hepatobiliary and Pancreatic Surgery. 2. ed. 1996

8. Sabiston. Textbook of Surgery 17 ed., 2006, p.1112-1143

9. Timothy DS, Steven AC. Liver. Chapter 30, p 1139-1186. in Schwartz” S Principles of Surgery 18th ed., 2004

10. Thomas JN, Gordon AH. Pathophysology. International edition. 3th ed. P 369396, 2004

11. Sherlock S, Dooley J. Disease of the liver and biliary tract. 11-th ed. 2001

12. Sultanov H.A. Carrahi Xastaliklar. Bak1 2000

13. Surgical Anatomy and Embriology. Surgical Clinics of North America Vol 73, no 4, 1993

14. William RJ. Liver and Portal venouse system. In: Gerard MD, Lawrence WW, Current Surgical Diagnosis and Treatment. $12^{\text {th }}$ edition, 2006, p 539572

15. Zudema GD. Shackelford's Surgery of Alimentary tract, Vol III, 5th ed, 2006

\section{Olavo adobiyyat}

1. Chen MJ, Lin YC, Wu MS. Optimization of timing of endoscopic variceal ligation of esophageal varices. Am J Gastroenterol. 2006 Apr;101(4):908.

2. Chen WC, Lo GH, Tsai WL, Hsu PI, Lin CK, Lai KH. Emergency endoscopic variceal ligation versus somatostatin for acute esophageal variceal bleeding. J Chin Med Assoc. 2006 feb;69(2):60-7. 
3. Chong CF. Esophageal rupture due to Sengstaken-Blakemore tube misplacement. World J Gastroenterol. 2005 Nov 7;11(41):6563-5.

4. Duvnjak M, Barsic N, Tomasic V, Jukic LV, Lerotic I. Usted blood requirement index as indicator of failure to control acute variceal bleeding.Croat Med J. 2006 Jun;47(3):398-403.

5. De Gottardi A, Dufour JF. Oesophageal and fundic variceal bleeding. Ther Umsch. 2006 May;63(5):295-9.

6. de Franchis R. Endoscopy critics vs. endoscopy enthusiasts for primary prophylaxis of variceal bleeding. Hepatology. 2006 Jan;43(1):24-6.

7. Elwood DR, Pomposelli JJ, Pomfret EA, Lewis WD, Jenkins RL. Distal splenorenal shunt: preferred treatment for recurrent variceal hemorrhage in the patient with well-compensated cirrhosis. Arch Surg. 2006 Apr;141(4):385-8; discussion 388.

8. Garcia-Pagan JC, Bosch J. Endoscopic band ligation in the treatment of portal hypertension. Nat Clin Pract Gastroenterol Hepatol. 2005 Nov;2(11):526-35.

9. Henderson JM, Boyer TD, Kutner MH, Galloway JR, Rikkers LF, Jeffers LJ, Abu-Elmagd K, Connor J; DIVERT Study Group. Distal splenorenal shunt versus transjugular intrahepatic portal systematic shunt for variceal bleeding: a randomized trial. Gastroenterology. 2006 May;130(6):1643-51.

10. Hou MC. Developments in the treatment of acute esophageal variceal bleeding. J Chin Med Assoc. 2006 Feb;69(2):55-7.

11. Jacobi D, de Muret A, Arbeille B, Perarnau JM. Transjugular intrahepatic portosystemic shunt for the treatment of portal hypertension secondary to non-cirrhotic perisinusoidal hepatic fibrosis. Eur J Gastroenterol Hepatol. 2006 May; 18(5):549-51.

12. Krige JE, Bornman PC, Shaw JM, Apostolou C. Complications of endoscopic variceal therapy. S Afr J Surg. 2005 Nov;43(4):177-88, 190-4.

13. Kojima $\mathrm{K}$, Imazu $\mathrm{H}$, Matsumura $\mathrm{M}$, Honda $\mathrm{Y}$, Umemoto $\mathrm{N}$, Moriyasu $\mathrm{H}$, Orihashi T, Uejima M, Morioka C, Komeda Y, Uemura M, Yoshiji H, Fukui H. Sclerotherapy for gastric fundal variceal bleeding: is complete obliteration possible without cyanoacrylate? J Gastroenterol Hepatol. 2005 Nov;20(11):1701-6.

14. Liu H, Gaskari SA, Lee SS. Cardiac and vascular changes in cirrhosis: pathogenic mechanisms. World J Gastroenterol. 2006 Feb 14;12(6):837-42.

15. Lay CS, Tsai YT, Lee FY, Lai YL, Yu CJ, Chen CB, Peng CY. Endoscopic variceal ligation versus propranolol in prophylaxis of first variceal bleeding in patients with cirrhosis. J Gastroenterol Hepatol. 2006 Feb;21(2):413-9.

16. Laleman W, Landeghem L, Wilmer A, Fevery J, Nevens F. Portal hypertension: from pathophysiology to clinical practice. Liver Int. 2005 Dec;25(6):1079-90.

17. Ling SC. Should children with esophageal varices receive beta-blockers for the primary prevention of variceal hemorrhage? Can J Gastroenterol. 2005 Nov;19(11):661-6.

18. May G, Musa D. Best evidence topic report. The use of intravenous terlipressin in non-variceal upper GI bleeds. Emerg Med J. 2006 May;23(5):400-1. 
19. Paramesh AS, Meiners R, Fairchild RB, Sane S, George M, Van ThielDH. Retroperitoneal varices presenting as an adrenal pseudotumor in a cirrhotic patient.WMJ. 2006 Jun;105(4):44-6.

20. Pal S, Radhakrishna P, Sahni P, Pande GK, Nundy S, Chattopadhyay TK. Prophylactic surgery in non-cirrhotic portal fibrosis:is it worthwhile? Indian J Gastroenterol. 2005 Nov-Dec;24(6):239-42.

21. Rockey DC. Pharmacologic therapy for gastrointestinal bleeding due to portal hypertension and esophageal varices. Curr Gastroenterol Rep. 2006 Feb;8(1):7-13.

22. Schepke M. Primary prevention of variceal bleeding in cirrhosis. Dtsch Med Wochenschr. 2006 Jun 2;131(22):1269-72.

23. Stiegmann GV. Endoscopic approaches to upper gastrointestinal bleeding. Am Surg. 2006 Feb;72(2):111-5. Ohmoto K, Yoshioka N, Tomiyama Y, Shibata N, Takesue M, Yoshida K, Kuboki M, Yamamoto S. Improved prognosis of cirrhosis patients with esophageal varices and thrombocytopenia treated by endoscopic variceal ligation plus partial splenic embolization. Dig Dis Sci. 2006 Feb;51(2):352-8.

24. Tang CP, Huang YS, Tsay SH, Chang FY, Lee SD. Nonalcoholic fatty liver disease manifesting esophageal variceal bleeding. J Chin Med Assoc. 2006 Apr;69(4):175-8.

25. Tan PC, Hou MC, Lin HC, Liu TT, Lee FY, Chang FY, Lee SD. A randomized trial of endoscopic treatment of acute gastric variceal hemorrhage: N-butyl-2-cyanoacrylate injection versus band ligation. Hepatology. 2006 Apr;43(4):690-7. Erratum in: Hepatology. 2006 Jun;43(6):1410.

26. Turnes J, Garcia-Pagan JC, Abraldes JG, Hernandez-Guerra M, Dell'Era A, Bosch J. Pharmacological reduction of portal pressure and long-term risk of first variceal bleeding in patients with cirrhosis. Am J Gastroenterol. 2006 Mar;101(3):506-12.

27. Triantos C, Vlachogiannakos J, Manolakopoulos S, Burroughs A, Avgerinos A. Is banding ligation for primary prevention of variceal bleeding as effective as beta-blockers, and is it safe? Hepatology. 2006 Jan;43(1):196-7; discussion 197-8.

28. Yan BM, Lee SS. Emergency management of bleeding esophageal varices: drugs, bands or sleep? Can J Gastroenterol. 2006 Mar;20(3):165-70.

29. Zaman A, Chalasani N. Bleeding caused by portal hypertension. Gastroenterol Clin North Am. 2005 Dec;34(4):623-42.

30. Zamora CA, Sugimoto K, Tsurusaki M, Izaki K, Fukuda T, Matsumoto S, Kuwata Y, Kawasaki R, Taniguchi T, Hirota S, Sugimura K. Endovascular obliteration of bleeding duodenal varices in patients with liver cirrhosis. Eur Radiol. 2006 Jan;16(1):73-9. Epub 2005 Apr 26. 
Seminar 5

ASSíT 


\section{TORIFI}

Assit qarın boşluğuna maye toplanmasına deyilir.

Normal halda periton boşluğuna gündə təxminən 10 litrə yaxın maye daxil olur və çıxır. İfrazat və sorulma arasındakı tarazlıq periton boşluğunda kiçik miqdarda (50$100 \mathrm{ml}$ maye orqanların hərəkətliliyinə və yapışmamasına xidmət edir) mayenin sabitliyini təmin edir. Bu tarazlığın pozulması periton boşluğuna 30-40 litrə qədər mayenin toplanmasına gətirib çıxara bilir.

Peritonda ifrazat və sorulma arasındakı tarazlığ 1 pozan bir neçə mexanizm məlumdur: hipertenziya, osmotik, sekresiya, eksudasiya, ekstravazasiya və limfatik blok.

Hipertenziya kapilyardaxili təzyiqi artıraraq assit və ödem törədir ki, bu da PH və ürək çatışmazlığı üçün xarakterikdir. Qanda onkotik tozyiqin azalmasına səbəb olan hipoproteinemiya və hipoalbuminemiya (sirroz, nefrotik sindrom) suyun toxumaaras1 sahəyə keçməsinə səbəb olur. Bundan başqa toxumaarası sahəyə onkotik aktiv maddələrin toplanması (məsələn, miksedema) da suyun damar yatağından toxumaarası sahəyə keçməsini artıra bilir.

Bəzi epitelial şişlər (mezotelioma, peritoneal karsinomatoz) seliyəbənzər şirə ifraz edərək assit törədə bilirlər.

Eksudasiya kapilyar keçiriciliyinin artması nəticəsində plazmanın çıxışıdır və adətən proteinlə zəngin assitə səbəb olur. İltihabi xəstəliklərin assit törətməsi məhz bu mexanizmlədir.

Ekstravazasiya zədələnmə nəticəsində boşluqlu və vəzili orqanların şirəsinin kənara çıxmasıdır. Öd, pankreas mədə-bağırsaq deşilmələri uyğun tərkibli assitlər törədə bilir. Limfatik axacaqlarda tuxanma və ya artıq yüklənmə limfatik mayenin periton boşluğuna sızmasına səbəb olur. Bu qarın boşluğu orqanları və limfatik sistem şişlərindəki assitin əmələ gəlməsində əsas rol oynayan mexanizmdir.

Assitlərin təxminən 80-85\%-i sirroz mənşəlidir, təxminən 5-10\%-i qarışıq mənşəli, 3\%-i ürək, 2\%-i karsinomatoz mənşəlidir, digərləri isə, 2\% təşkil edir.

\section{TOSNIFATI}


Assitin rənginə, tərkibinə, səbəbinə, patogenezinə görə müxtəlif təsnifatı var. Klassik olaraq assit tərkibindəki protein miqdarına görə transudativ (protein $<2,5 \mathrm{q} / \mathrm{dl}$ ) və eksudativ (protein $>2,5 \mathrm{q} / \mathrm{dl}$ ) növlərə ayrılır. Son illərki klinik təcrübə və tədqiqatlar göstərir ki, transudat/eksudat prinsipinə görə təsnifat nəzəri olaraq effektiv görünsə də, diaqnostikada yüksək faydalılıq göstərmir. Məsələn, sirrozda transudativ assit qəbul olunmasına baxmayaraq bəzən yüksək protein miqdarı ola bilər. Yaxud, qarışıq səbəbli assitlərdə diaqnostik çətinlik yarana bilir. Digər tərəfdən, sirrozda diuretiklər və parasentez mayedə protein konsentrasiyasını dəyişdirə bilir. Kardiak assitlərdə də protein yüksək olur.

Hazırda assitlərin plazma-assit albumin fərqinə (PAAF) əsaslanan klassifikasiyasına üstünlük verilir. Plazmadakı albumin miqdarından assitdəki albumin miqdarını çıxdıqdan sonra alınan fərqin qiymətinə görə yüksək və aşağı fərqli assitlər ayırd edilir (Cədval 1). Yüksək fərqli assit (PAAF $>1,1$ q/dl) 97\% həssaslıqla PH-1 göstərir, o cümlədən sağ ürək yetməzliyində və miksodemada olur. Aşağı fərq (PAAF $<1,1$ q/dl) isə $97 \%$ həssaslıqla $\mathrm{PH}-1$ inkar edir və iltihabı, neoplastik, ekstravazasiya, limfatik assitlər üçün xarakterikdir. Nefrotik sindromda da aşağı fərqli assit təyin edilir.

\section{Cədvəl 1. Yüksək və aşağı fərqli assitlərin səbəbləri}

\begin{tabular}{|c|c|}
\hline $\begin{array}{l}\text { Yüksək fərqli assit } \\
\text { PAAF } \geq 1,1 \text { q/dl }\end{array}$ & $\begin{array}{l}\text { Aşağı forqli assit } \\
\text { PAAF }<1,1 \text { q/dl }\end{array}$ \\
\hline Sirroz & Peritoneal karsinomatoz \\
\hline Alkoqol hepatitis & TBC peritoniti \\
\hline Kardial assit & Pankreatik assit \\
\hline Kəskin Qc yetməzliyi & Biliar assit \\
\hline Baddi-Kiari sindromu & Bağırsaq perforasiyası \\
\hline Portal vena trombozu & Nefrotik sindrom \\
\hline Venooklüziv xəstəliklər & Limfatik blok \\
\hline Hamiləlikdə yağlı Qc & Serozitlər \\
\hline Qarışıq assit & \\
\hline
\end{tabular}

PORTAL HİPERTENZIYYADA ASSITIN PATOGENEZI 
$\mathrm{PH}$ və Qc xəstəliklərində assitin baş verməsində əsasən 3 mexanizm rol oynayır: tozyiqin artması, su vo elektrolit tutulması vo onkotik tozyiqin azalması (Şəkil 1).

Portal hipertenziya kompensator olaraq limfatik sistemin yüklənməsinə gətirib çıxarır. Limfatik yüklənmə artıq olduqda intrahepatik və portal kapilyarlarda hipertenziyanı azalda bilmir və hər iki damar sistemindən (qan və limfa) boşluğa transudasiya baş verir.

Assitin ikinci mexanizmi $\mathrm{Na}^{+}$və suyun böyrəklərdə reabsorbsiyasının artması və böyrək disfunksiyasıdır ki, bu proseslərdə, renin-angiotenzin-aldesteron sisteminin (RAAS) aktivləşməsi və ADH artımı mühüm rol oynayır.

PH və sirrozda RAAS aktivləşməsinin birinci səbəbi qan dövranına keçən vazodilatator-maddələrinin (NO, qlukaqon, substansiya $\mathrm{P}$ və s.) törətdiyi sistemik vazodilatasiyadır. İkinci mexanizmi isə, plazmanın peritona sekvestrasiyası nəticəsində dövr edən qanın azalmasıdır. Yəni, assitin özü onu törədən mexanizmi $\left(\mathrm{Na}^{+}\right.$və su tutulması) aktivləşdirir və nəticədə qüsurlu dövran yaranır.

Qc xəstəlikləri və PH-da assitin əmələ gəlməsinə səbəb olan üçüncü mexanizm hipoalbuminemiya və onkotik təzyiqin azalmasıdır. Hipoosmos plazmadakı suyun toxumaarası sahəyə və peritona keçməsinə şərait yaradaraq ödem və assitə gətirib çıxarır.

\section{GEDİŞi}

PH-da assit ən çox rast gələn əlamətlərdən biridir. Gedişinə görə yüngül, orta, refrakter və ă̆ırlaşmış (gərgin, spontan bakterial peritonit) assit qeyd etmək olar. Yüngül assit klinik təyin edilmir, USM və KT-də görünür. Orta dəracəli assit qarında şişmə törədir və klinik təyin olunur: perkutor kütlük, dalğalanma və s. Orta dərəcəli assit diuretik müalicəyə tabe olur. Refrakter assit yüksək dozadakı diuretiklərə (spironolakton $400 \mathrm{mq} /$ gün, furosemid $160 \mathrm{mq} /$ gün) cavab verməyən assitdə deyilir. Refrakter assit müalicə olunmadıqda qarındaxili təzyiqi artıraraq ağciyəri, böyrəkləri, venaları sıxaraq tənəffüs və böyrək yetməzliyinə, hipotoniyaya səbəb olur. Buna gərgin assit deyilir. Ona görə də təcili parasentez tələb edir. Assitin digər ağırlaşmaları infeksiya va yırtıqdır. 


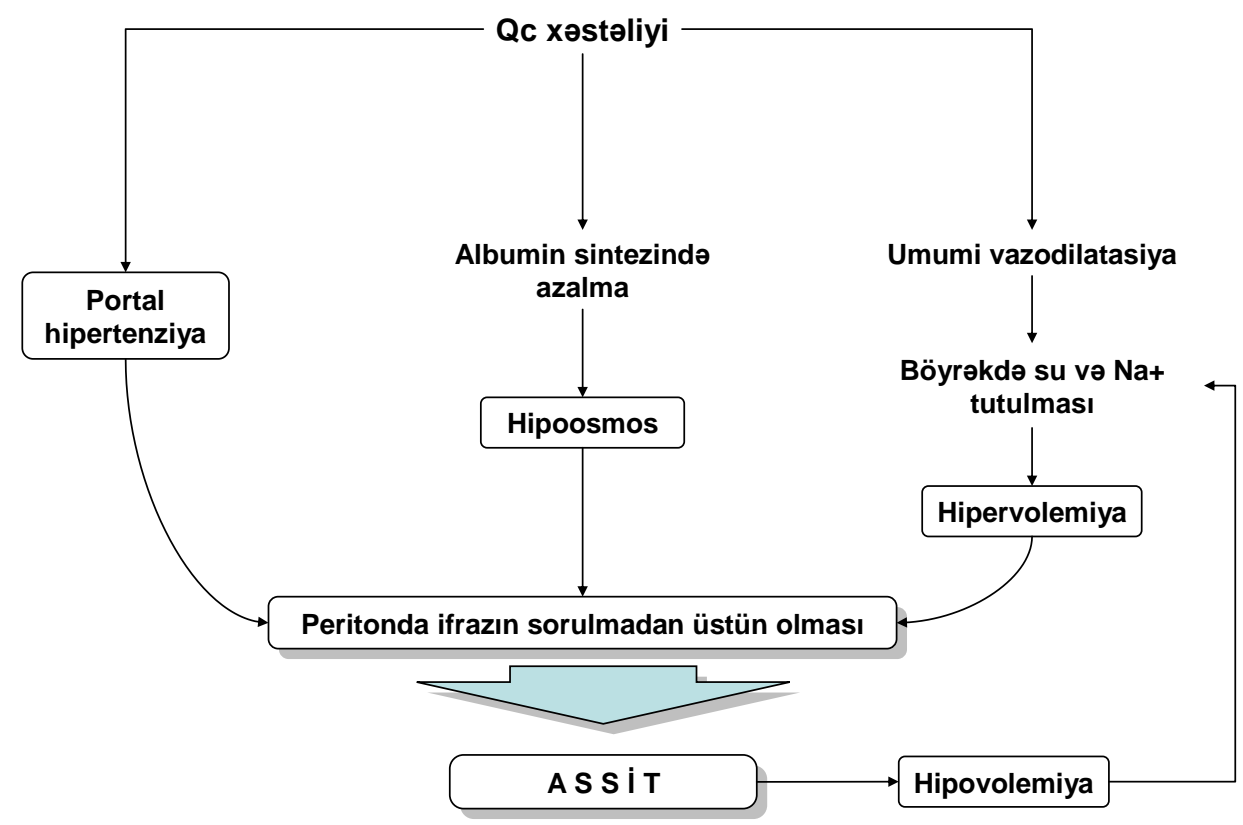

Şəkil 1. PH-da assitin patogenezi

\section{DİAQNOSTIKASI}

Assitin diaqnostikasında üç əsas məsələdən birincisi, assitin olub-olmadığg, ikincisi, səbəbinin təyini, üçüncüsü isə, ă̆ırlaşmanın təyinidir. Kiçik assitlərin klinik əlamətləri zəifdir və USM və/və ya KT ilə təyin olunur. Qarında şişkinlik törədən orta və böyük assitlərin klinik təyini bəzən çətin olur və köp, kütlə, köklük və s. ilə differensasiya etmək lazım gəlir. Dalğalanma, su qaçma əlamətləri assit üçün xarakterikdir və dəqiqləşdirmək üçün, xüsəsn kistşəkilli törəmələrdən fərqləndirmək məqsədi ilə USM və KT lazımdır.

Assitin səbəbini təyin etmək üçün klinik və görüntüləmə müayinələri yetrəsiz olarsa punksiya edərək assitik mayeni müayinə etmək lazımdır (Şəkil 2). İlk olaraq assitdə qan hüceyrələri, protein miqdarı və albumin miqdarı (plazmadakı albumin də eyni vaxtda araşdırılır) qiymətləndirilir və PAAF hesablanır. Assitin rəngi və şəffaflığına görə səbəbini təyin etmək həmişə doğru nəticə vermir.

PAAF-a görə assitin yüksək, və ya aşağı fərqli olduğu müəyyənləşdirilir.

Aşağ1 fərqli (PAAF $<1,1$ q/dl) assitlərdə əlavə müayinələrlə (sitoloji, mikrobioloji, öd piqmenti, amilaza, qlükoza, LDH və b.) iltihabi, neoplastik, ekstravazasiya, limfatik səbəblər axtarılır. Aşağı fərqli assitdə aşağı protein $(<2,5 \mathrm{q} / \mathrm{dl})$ nefrotik sindroma 
xasdır, yüksək leykositoz, yüksək protein, aşağı qlükoza ( $<50 \mathrm{mq} / \mathrm{dl})$, yüksək LDH (>250 tv/l) və qarışıq infeksiya ikincili peritonitlərdə görünür. Atipik hüceyrələr peritonal karsinomatozda rast gəlir. Vərəm peritonitində limfositar artımla yanaşı turşuya davamlı bakteriyalar tapıla bilir (40-60\%). Diaqnozu dəqiqləşdirmək üçün laparoskopiya (“darı dənələri” və "kamança simi” görüntüləri) və biopsiya vacibdir. Assitdəki bilirubinin və amilazanın plazmadakından çox olması uyğun olaraq öd və pankreatik assiti göstərir.

Yüksək fərqli (PAAF>1,1 q/dl) assitdə üç patologiya - PH, sağ ürək yetməzliyi və miksedema arasında diferensasiya aparmaq lazımdır. Pastoz sifət, sərt ödemlər, aşağı $\mathrm{T}_{3}, \mathrm{~T}_{4}$, yüksək TSH miksedemanı göstərir. Yüksək PAAF və transudativ assit sirroz üçün xarakterikdir. Kardiak assitlərdə adətən total protein yüksək olur (2,5 q/dl). Lakin qarışıq assitlərdə (PH və sirroz fonunda tuberkulez, karsinomatoz, ikincili bakterial peritonit və s.) və Baddi-Kiari sindromunda da assit eksudativ ola bilər. Belə hallarda ilk növbədə kardioloji müayinələrlə (ağciyər R-qrafiyası, EKO, EKQ) kardiak assiti təsdiq və inkar etmək lazım gəlir. Sağ ürəyin atım fraksiyasının azalması $(<40 \%)$, aşağı boş venanın (ABV) genişlənməsi və tənəffüsdə dəyişməməsi, periferik ödemin daha bariz olması kardiak assiti göstərir.

Yüksək PAAF və proteinli assitlərdə ürək funksiyası normal olarsa sirroz fonunda inkişaf edən karsinomatozu, tuberkulyozu, ikincili peritonit və Baddi-Kiari sindromunu araşdırmaq lazımdır. Tuberkulyozu dəqiqləşdirmək üçün laparoskopik biopsiya məqsədəuyğundur. Atipik hüceyrələrin tapılması karsinomatozu təsdiqləyir. Nəhayət, üçüncü və ən tacili məsələ ă̆ırlaşmış və tacili müdaxilə tələb edən assitin olub-olmadığını təyinidir. Xüsusən, gərgin assit və peritonit (spontan bakterial peritonit və ikincili peritonit) təcili müalicə tələb edən vəziyyətlərdir. Gərgin qarın və qarının tənəffüsdə iştirak etməməsi gərgin assitin və ikincili bakterial peritonitin əlamətləridir. Belə vəziyyətlərdə ilk növbədə qarını mayedən boşaldıb dekompressiya etmək lazımdır və xəstədə ikincili peritoniti təsdiq və ya inkar etmək çox vacibdir. İkincili peritonit təcili cərrahi müdaxilə, spontan bakterial peritonit (SBP) isə, konservativ müalicə tələb edir. SBP üçün yüksək PAAF ( $>1,1$ q/dl) və aşağı albumin $(<1 \mathrm{q} / \mathrm{dl})$ xarakterikdir. Eksudativ assit, polimorfnüvəli leykositlər $(>250 / \mathrm{ml})$ və aşağı $\operatorname{PAAF}(<1,1 \mathrm{q} / \mathrm{dl})$ ikincili bakterial peritonit üçün xarakterikdir. İkincili peritoniti inkar etmək mümkün deyilsə təcili laparoskopiya lazım gəlir. 


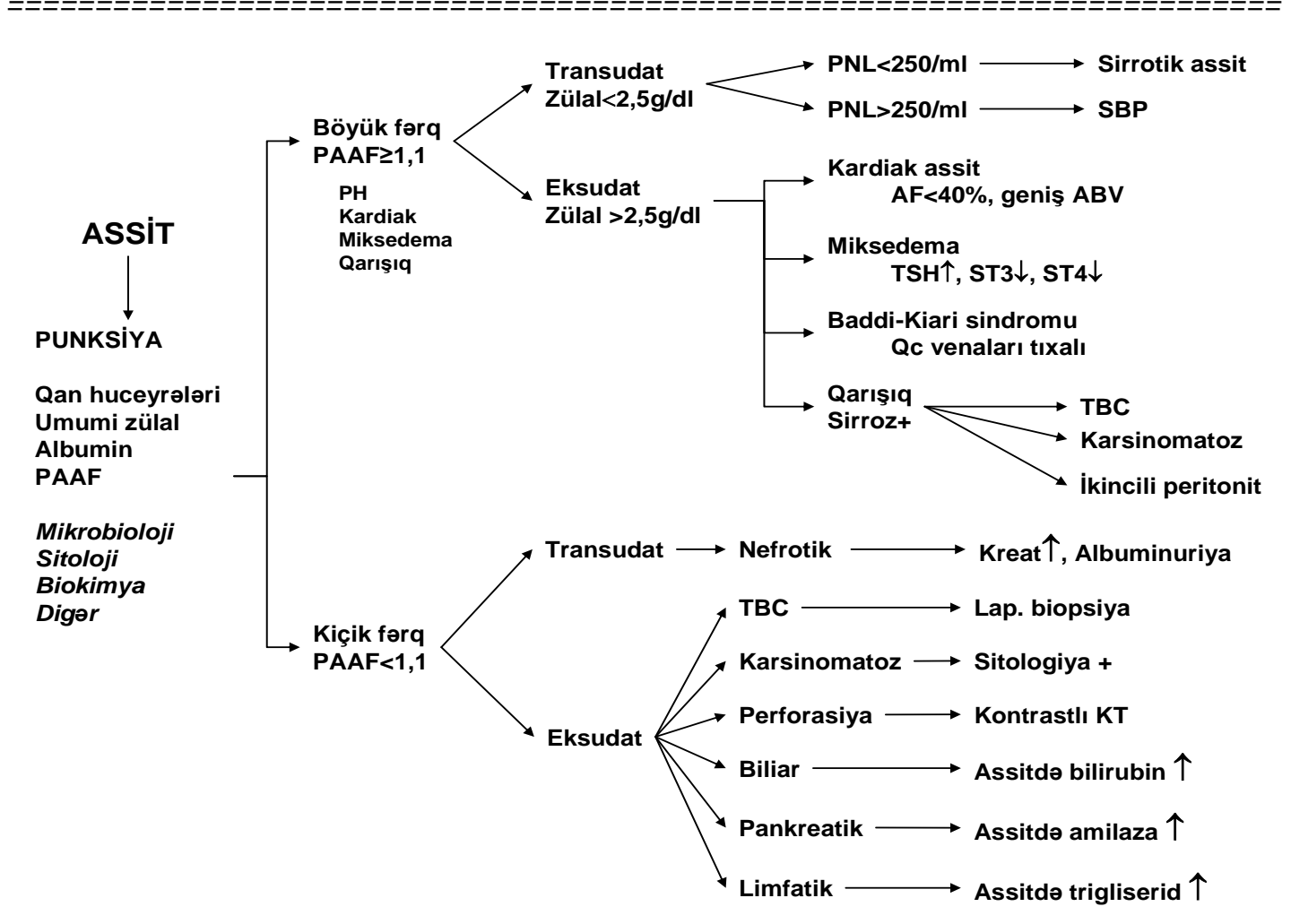

Şəkil 2. Assitdə diaqnostik alqoritm

\section{MÜALİCəSi}

Assitli xəstədə ilk hadəf tacili vaziyyatlara müdaxiladir (Şəkil 3).

Gərgin assitdə təcili olaraq parasentez edilir, periton boşaldılır. Kollaps və hepatorenal sindromun profilaktikası üçün eyni vaxtda kolloid (hər litrə 8-10 q albumin və ya dekstran) köçürmək lazımdır.

İkincili peritonitdə təcili laparoskopiya və ya laparotomiya lazımdır. Spontan bakterial peritonitdə albumin (1,5 q/kq/gün) və sefotaksim başlanılır.

İkinci müalicə hədəfi səbəbin aradan qaldırılmasıdır. Məsələn, tuberkulyozda vərəməleyhinə müalicə, miksedemada L-tiroksin, kardiak assitdə kardiotonik, biliar və pankreatik assitdə drenaj və düzəldici cərrahiyyə, endoskopik müdaxilə, karsinomatozda sitoreduktiv cərrahiyyə və kimyaterapiya və s.

Sirroz va PH mənşali assitlardə asas müalicə Qc Tx va PH-ın azaldılmasıdır. $\mathrm{Bu}$ mümkün olmadıqda ümumi hədəf - assitin patogenetik mexanizmlərinə təsir etmək lazım gəlir. İlk prinsip, su vo $\mathbf{N a}^{+}$qəbulunu azaltmaq vo diuretik istifadəsidir. 


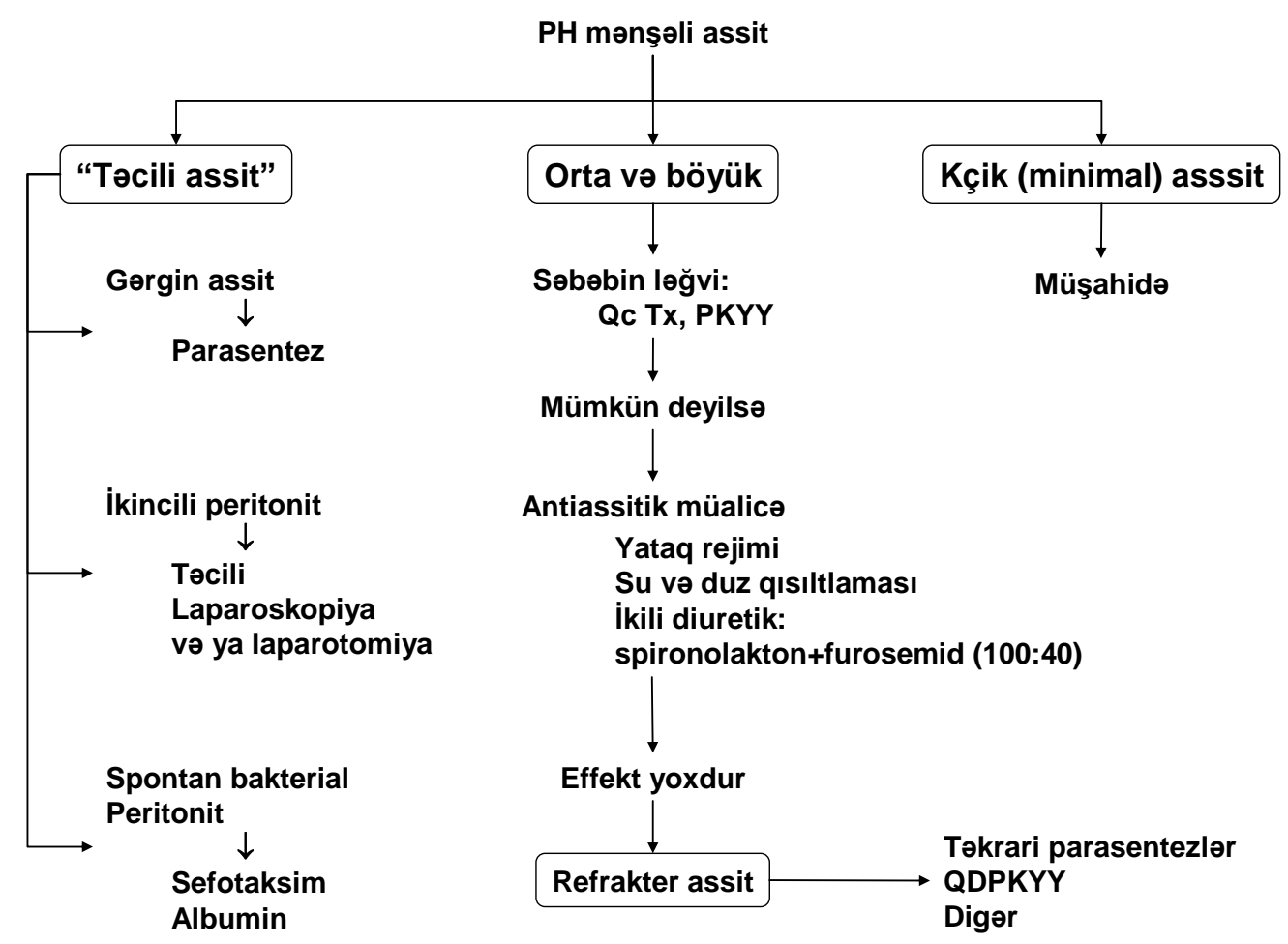

\section{Şəkil 3. PH mənşəli assitdə müalicə taktikası}

Xəstələrin gündəlik su qəbulu 1-5 L miqdarı, $\mathrm{Na}^{+}$isə 1 q-1 keçməməlidir. Bu tədbirlər assiti azaltmırsa diuretik lazım gəlir. Spironolakton və furosemid ən çox istifadə edilən diuretiklərdir. Bunların istifadəsinin standart dozası və şəkli qəbul olunmayıb. Bəzi müəlliflər 100-300 mq spironolaktonu gündə 3 dəfə istifadə edir, lazım gəlsə furosemidi (40 mq həftədə 2-3 dəfə) əlavə edir. Bəziləri isə, spironolakton-furosemid kombinasiyasını gündə 1 dəfə 100: 40 nisbətində istifadəsini tövsiyə edirlər. Lazım gəlsə bu doza 2 və 3 dəfə (spironolakton 200, $300 \mathrm{mq}+$ furosemid 80, $120 \mathrm{mq}$ ) artırıla bilər. Ogər xəstədə hipoantriemiya $\left(\mathrm{Na}^{+}<130 \mathrm{mmd} / \mathrm{l}\right)$ varsa əvvəlcə spironolakton təyin edilir, qanda $\mathrm{Na}^{+}$normallaşarsa gündəlik furosemid əlavə edilir. Hesab edilir ki, spironolakton/furosemid 100:40 nisbəti elektrolit səviyyəsini ciddi dəyişdirmir.

Yüksək doza diuretikə baxmayaraq (spironolakton 400+furosemid $160 \mathrm{mq}$ ) assit azalmırsa (refrakter assit) ilk növbədə xəstənin $\mathrm{Na}^{+}$və su qəbulunu azaltdığını yoxlamaq lazımdır. Buna riayət edən xəstədə refrakter assit varsa vaxtaşırı parasentez və ya $P K Y Y$ seçilə bilər. Peritono-venoz şunt YDDL və tutulma törədə bildiyi üçün hazırda istifadə edilmir. Vaxtaşırı parasentez (hər dəfə 3-5 1 maye çıxarma) asan 
üsuldur, lakin təkrarlamaq lazım gəlir və qarındaxili zədələnmə (qanaxma, perforasiya) törədə bilər.

Parasentez vaxtı HRS-in baş verməməsi üçün çıxarılan hər litr assitə 8-10 q albumin və ya dekstran-70 verilməlidir. QDPKYY refrakter assitin ən effektiv müalicəsidir, daha çox Tx gözləyən xəstələrdə tövsiyə edilir. Qc funksiyası saxlanılan xəstələrdə total və hissəvi PKYY tövsiyyə edilir. DSRYY assiti artıra bildiyi üçün refrakter assitdə tövsiyə edilmir.

\section{Osas ədəbiyyat}

1. Ağayev B.A. Cərrahi Xəstəliklər. Bakı 2001

2. Blumgart LH. Surgery of the Liver, Biliary tract and Pancreas. 4th ed. 2006

3. Cuschieri SA. Disorders of the liver. Module 10, p 321-374. in Cuschieri SA, Steel RJ, Moossa AR. Essentiale Surgical practice.. $4^{\text {th }}$ ed. 2002

4. Feldman M, Friedman LS, Sleisenger MH. Sleisenger and Fordtran's Gastrointestinal and Liver diseases. $7^{\text {th }}$ ed. Vol II, 2002.

5. Modern Surgical Care. 2 ed. Vol I, 1998

6. Oxford textbook of Surgery V.1,2004

7. Rob and Smith's Hepatobiliary and Pancreatic Surgery. 2. ed. 1996

8. Sabiston. Textbook of Surgery 17 ed., 2006, p.1112-1143

9. Timothy DS, Steven AC. Liver. Chapter 30, p 1139-1186. in Schwartz" ${ }_{S}$ Principles of Surgery18th ed., 2004

10. Thomas JN, Gordon AH. Pathophysology. International edition. 3th ed. P 369396, 2004

11. Sherlock S, Dooley J. Disease of the liver and biliary tract. 11-th ed. 2001

12. Sultanov H.A. Carrahi Xastaliklar. Bakı 2000

13. Surgical Anatomy and Embriology. Surgical Clinics of North America Vol 73, no 4, 1993

14. William RJ. Liver and Portal venouse system. In: Gerard MD, Lawrence WW, Current Surgical Diagnosis and Treatment. $12^{\text {th }}$ edition, 2006, p 539572

15. Zudema GD. Shackelford's Surgery of Alimentary tract, Vol III, 5th ed, 2006

\section{Olavə ədəbiyyat}

1. Deltenre P, Mathurin P, Barraud H, Bronowicki JP, Jacquet E, Puche P, Jaber S, Navarro F, Pageaux GP. Managing the complications of cirrhosis. Rev Prat. 2005 Sep 30;55(14):1555-63.

2. Kotiv BN, Basov SP. The role of portal hypertension and colloidosmotic blood pressure in the pathogenesis of ascitis in patients with hepatic cirrhosis. Klin Med (Mosk). 2006;84(3):46-9 
3. Mathews RE Jr, McGuire BM, Estrada CA. Outpatient management of cirrhosis: a narrative review. South Med J. 2006 Jun;99(6):600-6.

4. Sanyal AJ. Pros and cons of TIPS for refractory ascites. J Hepatol. 2005 Dec;43(6):924-5. Epub 2005 Oct 6.

5. Sandhu BS, Sanyal AJ. Management of ascites in cirrhosis. Clin Liver Dis. 2005 Nov;9(4):715-32.

6. Wong F. The use of TIPS in chronic liver disease. Ann Hepatol. 2006 Jan-Mar;5(1):5-15. 
Seminar 6

\section{HEPATÍK ENSEFALOPATIYA}




\section{TORIFI}

Hepatik ensefalopatiya neyro-psixoloji pozulma olub, kəskin və xronik qaraciyər xəstəliklərinin beyin funksiyalarında törətdiyi geriyədönən və ləngimə xarakterli dəyişiklərdir.

Portosistemik şunt (bağırsaqdan gələn fizioloji və toksik maddələrin qaraciyərdə zərərsizləşməməsi) və beyindəki dəyişikliklər hepatik ensefalopatiyanın baş verməsində önəmli rol oynayır. İlk növbədə beyin qabı̆̆ına məxsus intellektual (ayıqlıq, yaddaş, xarakter, qavrama, danışma, diqqət və s.) və hərəkətə nəzarət funksiyaları pozulur. Proses irəlilədikcə qabığaltı mərkəzlərin fəaliyyəti, hətta tənəffüs mərkəzi də dayana bilir. Bu pozulmaların əksəriyyəti geriyə dönə bilir.

\section{ETIOLLOGIYASI}

Səbəinə görə hepatik ensofalopatiya üç tipə ayrılır: kəskin, şunt və xroniki. Kəskin ensefalopatiya qaraciyərin kəskin diffuz nekrozu (kəskin qaraciyər yetməzliyi) nəticəsində meydana gəlir. Şunt ensefalopatiyaları Qc-i normal olan, lakin, portal sistemlə umumi qan dövranı arasında yaranan təbii (portal hipertenziya nəticəsində geniş kollaterallar), cərrahi (PKYY-lar) və ya endovaskulyar (QDPKYY) yanyollardan sonra meydana çıxır. Xroniki ensefalopatiya isə, xroniki Qc xəstəlikləri, xüsusən, sirroz nəticəsində baş verən neyro-psixoloji pozulmaya deyilir.

\section{PATOGENEZI}

Neyro-sinaptik disfunksiya, yəni, neyronların funksiyalarının və neyronlar arasındakı əlaqələrin pozulması ensefalopatiyanın baş verməsində bilavasitə rol oynayan prosesdir. Hepatik ensefalopatiyada bu proseslərə gətirib çıxaran mexanizmlər portosistemik şunt (neyrotoksikoz) va beyin ödemidir (Şəkil 1).

Porto-sistemik şunt bağırsaqdan çıxan qanın zərərsizləşmədən ümumi dövrana keçməsidir və iki səbəbdən meydana gələ bilər: hepatocellular yetməzlik və yanyollar. Hepatosellular yetməzlik (disfunksiya) qaraciyərə gələn qanın hepatositlərdə yetərsiz təmizlənməsinə, kollateral və yanyollar isə, qanın hepatositlərdən yankeçməsinə səbəb olur. 


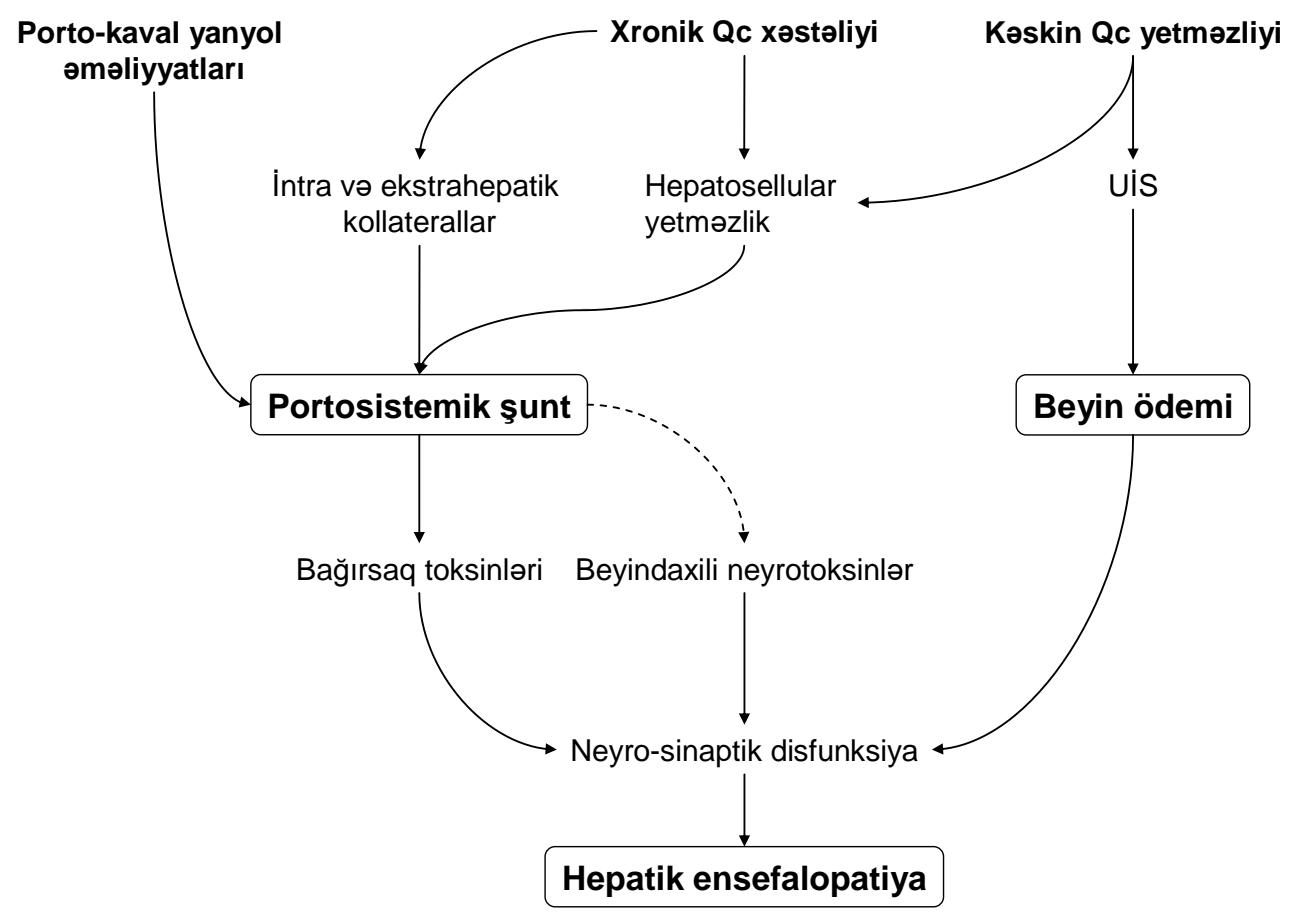

Şəkil 1. Hepatik ensefalopatiyanın patogenezi

Hər iki proses də, təkbaşına ensefaliyaya törədə bilir. Qaraciyərdə zərərsizləşməyən toksinlər beyində sinir əlaqələrinin (neyrotransmissiyanın) və neyronal funksiyaların pozulmasına gətirib çıxarır. Әmələ gəlmə yerinə görə neyrotoksinlər bağırsaq və beyin mənşəli ola bilər.

Bağırsaq mənşəli toksinlərə ammonyak, qamma-aminoyağ turşusu (QAYT), merkaptanlar, yalançı neyromediatorlar və s. aid edilir.

Ammonyak iki mənbədə - toxumalarda mübadilə nəticəsində və bağırsaqlarda mikroflora tərəfindən istehsal olunur, iki yolla daşınır - ammonyak və glutamin, iki yolla çıxarılır - qaraciyərdə sidik cövhəri dövranı və böyrəkdə glutamin deaminasiyası. Qaraciyər yetməzliyi və kollaterallar bağırsaqdan və orqanlardan gələn ammonyakın beyinə çoxlu miqdarda daxil olmasına səbəb olur. Ammonyak astrositlərdə glutamatdan glutaminin əmələ gəlməsinə, glutamin isə, neyronlarda glutamatın sintezinə şərait yaradır. Glütamat neyronlarda önəmli mediatordur və Krebs dövranının vacib komponenti olan $\alpha$-ketoglutaratdan sintez olunur. Hesab edilir ki, ammonyak artışı neyronlarda glutamatı artıraraq, $\alpha$-ketoglutaratı isə, azaldaraq neyrotransmissiyanı və neyron metabolizmini pozur. 
Ammonyak nəzəriyyasi hazırda xronik və kəskinloşmiş ensefalopatiyalarda ön planda duran nəzəriyyadir və klinik olaraq özünü müəyyən qadər do doğrultmuşdur.

QAYT (qamma-amino-yağ turşusu) sinir sistemində ən önəmli ləngidici mediatordur, bağırsaqda və beyində əmələ gəlir. QAYT təsirini adətən benzodiazepin reseptorları ilə birlikdə göstərir. Hesab edilir ki, QAYT təkbaşına yox, benzodiazepin reseptorlarında və liqandlarda dəyişikliklə birlikdə ensefalopatiyada rol oynayır.

Yalançı neyromediatorlar adlanan və aromatik aminturşuların (triptofan, tyrozin) məhsulu olan aralıq maddələr dopamin, nonadrenalin və serotonin reseptorlarına bağlanaraq təsir göstərirlər. Qaraciyər xəstəlikləri qanda aromatik aminturşuların zincirli aminturşulara nəzərən artmasına və beyində daha çox toplanaraq belə təsir göstərməsinə şərait yaradır.

Bunlardan başqa bağırsaqdan gələn digər maddələr (merkaptonlar və $\mathrm{s}$ ) neyrotoksikozda də rol oynayır.

Neyrotoksinlərin ikinci monbəsi beyin sayılır. Hesab edilir ki, qaraciyər xəstəliklərində beyindəki benzodiazepin reseptorlarında dəyişikliklər baş verir və benzodiazepinə bənzor mediatorlar artır ki, bunlar da ləngidici effektin meydana gəlməsində böyük rol oynayır.

Son illərki tədqiqatlar gəstərir ki, hepatik ensefalopatiya vaxtı benzodiazepin və QAYYT ilə yanaşı beyindəki neyrosteroidlərin səviyyəsində də dəyişiklik baş verir.

Qeyd etmək lazımdır ki, portosistemk şunt və neyrotoksikoz xronik və şunt ensefalopatiyalarında əsas patogenetik mexanizmlər sayılır. Kollaterallar və yanyolların torətdiyi yankeçmə mexanizmi şunt ensefalopatiyasının əsasında durur. Xronik ensefalopatiyalarda isə, hepatosellular yetməzlik və yankeçmə mexanizmləri birlikdə rol oynayır.

Beyin ödemi kəskin qaraciyər yetməzliyindəki hepatik ensefalopatiyada aparıcı mexanizm sayılır. Beyin ödeminin inkişaf mexanizmləri dəqiq məlum deyil. Hesab edilir ki, hepatosellular yetməzliyin törətdiyi neyrotoksikozla yanaşı UIS (umumi iltihab sindromu, intoksikasiya) və sepsis beyin ödeminin baş verməsində rol oynayır. 


\section{GEDIŞ̦I Və KLINIKKASI}

Etiopatogenezinə və gedişinə görə hepatik ensefalopatiyanın üç klinik forması var: kaskin, şunt va xronik.

Kəskin ensefalopatiya kəskin qaraciyər yetməzliyində meydana çıxır, beyin ödemi əsas patogenetik mexanizmidir və yüksək letallıqla seyr edir (80\%).

Xronik qaraciyər xəstəliklərində çox rastlanan və əsasən portosistemik şunt toksikozu nəticəsində baş verən xronik ensefalopatiya isə, müalicəyə tabe olur və adətən yüksək letallıq törətmir.

Xronik ensefalopatiya 3 klinik şəkildə görünür: subklinik, klinik və kaskinlaşmiş (ă̆ırlaşmış).

Subklinik və ya gizli ensefaloratiyada adi klinik müayinələrdə beyin fəaliyyəti normal görünsə də, xüsusi neyro-psixoloji testlərlə intellektdə və hərəkətlərdə incə dəyişikliklər təyin edilir.

Klinik ensefalaopatiyada klinik əlamətlər bariz şəkildədir və yavaş artan ensefalopatiya qeyd edilir.

Kəskinləşmiş və ya ağırlaşmış forma isə, xroniki ensefalopatiyanın kəskin dərinləşməsidir və adətən müəyyən ağırlaşdırıcı amillərin təsiri nəticəsində baş verir. Ensefalopatiyanı ağırlaşdıran amilləri 2 qrupa bölmək olar: nitrogeni (ammonyakı) artıranlar və qeyri-nitrogenoz amillər.

Qaraciyər funksiyası pozulmayan xəstələrdə yanyol əməliyyatları və ya geniş kollaterallar nəticəsində baş verən şunt (yanyol) ensefalopatiyası bir çox cəhətlərinə görə xronik ensefalopatiyaya bənzəyir. Yanyol kiçilərsə və ya aradan qalxarsa ensefalopatiya geriyə inkişaf edə bilir. Lakin yanyol davam edərsə prosesə hepatosellular yetməzlik də qoşulur və ensefalopatiyanı ağırlaşdıra bilir. Bununla yanaşı ağırlaşdırıcı amillər şunt ensefalopatiyasını da dərinləşdir.

Ağırlıq dərəcəsinə görə hepatik ensefalopatiyanın 4 dərəcəsi müəyyən edilir.

I dərəcə üçün diqqət pozulması və xarakter dəyişikliyi, II dərəcə üçün yaddaşın pisləşməsi və tremor, III dərəcə üçün çaşma, qarışdırma, amnesiya, asteniksis, danışmanın yavaşıması, IV dərəcə üçün isə, koma - reflekslərin itməsi, xarakterikdir.

\section{DİAQNOSTIKKASI}


Kəskin və xronik qaraciyər xəstəliklərində və yanyol əməliyyatlarından sonra ensfalopatiyaya şübhə yaranmalıdır. Ogər bu xəstələrdə davranış dəyişikliyi olarsa ensefalopatiyaya şübhə daha da artır.

Ensefalopatiyanın təyinində klinik əlamətlərə, xüsusi testlərə və MRT-yə istinad edilir. Klinik müayinə ilə intellektual, hərəki və şüur fəaliyyətləri qiymətləndirilir.

Xüsusi testlə porto-sistemik indeks adlanan göstərici hesablanır. Bu test 5 göstəriciyə əsaslanır: 1) Rəqəmləri birləşdirmə və ya fiqur çəkmə vaxtı; 2) yaddaş testi; 3) EEG, 4) asteniksis (barmaqlar və bilək açıldıqda əlin titrəməsi- tremor), 5) Ammonyak miqdar1.

Son illərki tədqiqatlar göstərir ki, MRT-də solğun kürrənin (globus pallidus) hipotalamusa nəzərən T1-də hiperintens görünməsi hepatic ensefalopatiya üçün xarakterik əlamətdir.

Ensefalopatiyanın diaqnostikasında ikinci önəmli məsələ ă̆ırlaşdırıcı amilin müəyyənləşdirilməsidir. Nitrogeni artıran və ya qeyri-nitrogenoz amillərin təyini məqsədi ilə mədə-bağırsaq sistemi, qan dövranı, tənəffüs və su-duz sistemi yoxlanılır, qan təhlilləri, hətta qanda dərman müayinəsi aparmaq lazım gəlir.

\section{MÜALİCəSi}

Hepatik ensefalopatiyanın müalicəsində ilk hədəf əsas səbəbin - qaraciyər xəstəliyinin və porto-sistemik yanyolun aradan qaldırılmasıdır. Oksər hallarda ensefalopatiya törədən kəskin və xroniki qaraciyər xəstəliklərinin (kəskin qaraciyər yetməzliyi, sirroz) yeganə müalicəsi Qc transplantasiyasıdır. Porto-sistemik yanyolun aradan qaldırılması üçün isə, şuntu kiçiltmək və ya bağlamaq lazım gəlir.

Səbəb aradan qaldırılmadıqda ensefalopatiyanın müəlicəsi üçün ikinci hədəf kimi patogenetik mexanizmlarə təsir strategiyası seçilir ki, bu da klinik formaya görə dəyişir.

Xroniki ensefalopatiyada əsas müalicə prinsipləri ağırlaşdırıcı amillərin aradan qaldırılması, ammonyakı azaltma, neyrotransmissiyanın, beyin metabolizminin korreksiyası və dəstək müalicəsidir (Codval 1). 


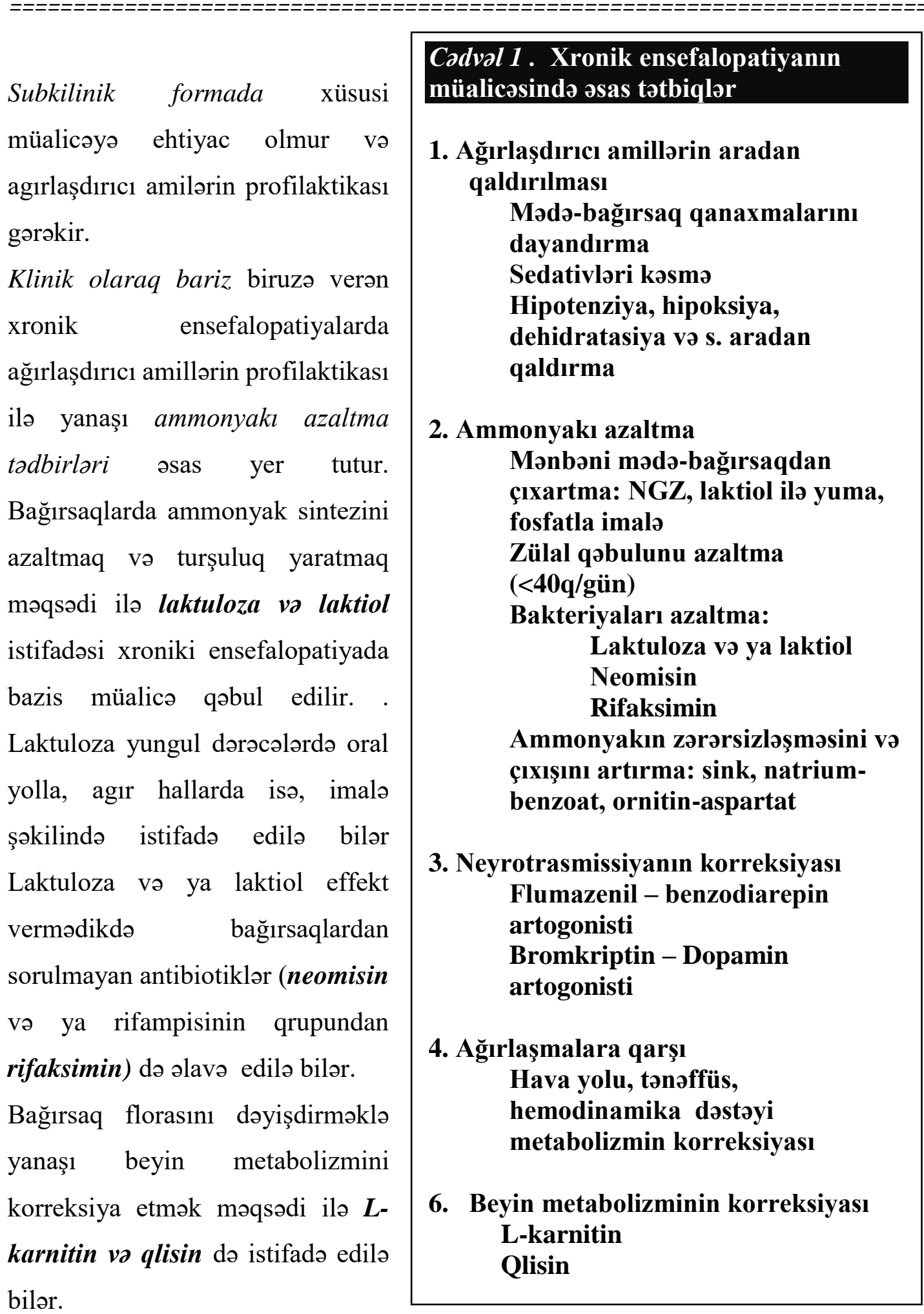

A ̆̆ırlaşmış xroniki ensefalopatiyada ağırlaşdırıcı amillərin aradn qaldırılması ilə yanaşı (mədə bağırsaq qanaxmasını dayandırma, bağırsaqları qan və eksogenoz proteinlərdən təmizləmə, sedativləri dayandırma, su-elektrik mübadiləsini düzəltmə və s.) ammonyakı azaltmaq və dəstək tədbirləri həyata keçirmək gərəkir. Belə xəstələrdə 
qanda ammonyakı azaltmaq üçün bir tərəfdən ammonyakın bağırsaqlarda istehsalını və sorulmasını azaltmaq, digər tərəfdən isə, orqanizmdən çıxmasını artırmaq lazımdır. Bu məqsədlə laktuloza (oral və ya imalə) ilə yanaşı venadaxili ornitin-aspartat (Hepamerth), natrium benzoat, sink istifadə edilir. Bəzi müəlliflər kəskinləşmiş ensefalopatiyanın müalicəsində benzodiazepin antoqonisti olan flumazenili tövsiyə edirlər. Son illər ensefalopatiyanın ağırlığını azaltmaq üçün süni qaraciyər sistemləri vo hepatosit köçürü̈lmosi də istifadə edilir.

Komatoz xəstələrdə havayolunu, tənəffüsü, qan dovranı və digər sistemləri nəzarət altına almaq lazımdır. Xüsusən, orqanizmin yetərli oksigenasiyasını və hiperventilyasiyanı təmin etmək üçün süni ventilyasıya və inotrop dəstək gərəkir.

Porto-sistemik ensefalopatiyada şuntu kiçiltmək və ya bağlamaq əsas tədbirdir. $\mathrm{Bu}$ mümkün deyilsə, müalicə xroniki ensefalopatiyada olduğu kimi aparılır.

Kəkin ensefalopatiyalarda xəstələrin sağalmasının ən effektiv müalicəsi Qc transplantasiyasıdır.

Qc transplantasiyası mümkün deyilsə, əsas müalicə beyin ödeminin azaldılmasına yönəlir. Xronik formadan fərqli olaraq, ammonyakı azaltma tədbirləri kəskin ensefalopatiyalarda yüksək effektiv deyil. Ödeməlehinə tədbirlər arasında ilk yeri hiperventilyasiya tutur. Bundan başqa osmotik diuretiklər (mannitol), deksametazon, thiopental istifadə edilə bilər. Bəzi klinikalarda komatoz xəstələrdə hipotermiya, hipertonik məhlullar va propofol sedasiyası totbiq edilir.

Medikamentoz müalicə effekt vermədikdə ekstrakorporal detioksikasiya üsulları (süni qaraciyər sistemləri, plazmoferez və s) istifadə edilə bilər. Bunlara baxmayaraq kəskin ensefalopatiyada letallıq yüksək dərəcə (70-80\%) seyr etməkdədir.

\section{Osas ədəbiyyat}

1. Blumgart LH. Surgery of the Liver, Biliary tract and Pancreas. 4th ed. 2006

2. Cuschieri SA. Disorders of the liver. Module 10, p 321-374. in Cuschieri SA, Steel RJ, Moossa AR. Essentiale Surgical practice.. $4^{\text {th }}$ ed. 2002

3. Feldman M, Friedman LS, Sleisenger MH. Sleisenger and Fordtran's Gastrointestinal and Liver diseases. $7^{\text {th }}$ ed. Vol II, 2002.

4. Modern Surgical Care. 2 ed. Vol I, 1998

5. Oxford textbook of Surgery V.1,2004

6. Rob and Smith's Hepatobiliary and Pancreatic Surgery. 2. ed. 1996

7. Sabiston. Textbook of Surgery 17 ed., 2006, p.1112-1143 
8. Timothy DS, Steven AC. Liver. Chapter 30, p 1139-1186. in Schwartz"s Principles of Surgery18th ed., 2004

9. Thomas JN, Gordon AH. Pathophysology. International edition. 3th ed. P 369-396, 2004

10. Sherlock S, Dooley J. Disease of the liver and biliary tract. 11-th ed. 2001

11. Surgical Anatomy and Embriology. Surgical Clinics of North America Vol 73, no 4, 1993

12. William RJ. Liver and Portal venouse system. In: Gerard MD, Lawrence WW, Current Surgical Diagnosis and Treatment. $12^{\text {th }}$ edition, 2006, p 539-572

\section{Olavə ədəbiyyat}

1. Al Mardini H, Douglass A, Record C. Amino acid challenge in patients with cirrhosis and control subjects: ammonia, plasma amino acid and EEG changes. Metab Brain Dis. 2006 Mar;21(1):1-10. Epub 2006 May 4.

2. Ardizzone G, Arrigo A, Schellino MM, Stratta C, Valzan S, Skurzak S, Andruetto P, Panio A, Ballaris MA, Lavezzo B, Salizzoni M, Cerutti E. Neurological complications of liver cirrhosis and orthotopic liver transplant. Transplant Proc. 2006 Apr;38(3):789-92.

3. Ahboucha S, Butterworth RF. Role of endogenous benzodiazepine ligands and their GABA-A--associated receptors in hepatic encephalopathy. Metab Brain Dis. 2005 Dec;20(4):425-37.

4. Binesh N, Huda A, Thomas MA, Wyckoff N, Bugbee M, Han S, Rasgon N, Davanzo P, Sayre J, Guze B, Martin P, Fawzy F. Hepatic encephalopathy: a neurochemical, neuroanatomical, and neuropsychological study. J Appl Clin Med Phys. 2006 Winter;7(1):86-96. Epub 2006 Feb 15.

5. Camus C, Lavoue S, Gacouin A, Le Tulzo Y, Lorho R, Boudjema K, Jacquelinet C, Thomas R. Molecular adsorbent recirculating system dialysis in patients with acute liver failure who are assessed for liver transplantation. Intensive Care Med. 2006 Aug 29

6. Charlton M. Branched-chain amino acid enriched supplements as therapy for liver disease. J Nutr. 2006 Jan;136(1 Suppl):295S-8S

7. Du WB, Li LJ, Huang JR, Yang Q, Liu XL, Li J, Chen YM, Cao HC, Xu W, Fu SZ, Chen YG. Effects of artificial liver support system on patients with acute or chronic liver failure. Transplant Proc. 2005 Dec;37(10):4359-64.

8. Deltenre P, Mathurin P, Barraud H, Bronowicki JP, Jacquet E, Puche P, Jaber S, Navarro F, Pageaux GP. Managing the complications of cirrhosis. Rev Prat. 2005 Sep 30;55(14):1555-63.

9. Fukuzawa T, Matsutani S, Maruyama H, Akiike T, Saisho H, Hattori T. Magnetic resonance images of the globus pallidus in patients with idiopathic portal hypertension: a quantitative analysis of the relationship between signal intensity and the grade of portosystemic shunt. J Gastroenterol Hepatol. 2006 May;21(5):902-7.

10. Faint V. The pathophysiology of hepatic encephalopathy. Nurs Crit Care. 2006 Mar-Apr;11(2):69-74

11. Festi D, Vestito A, Mazzella G, Roda E, Colecchia A. Management of hepatic encephalopathy: focus on antibiotic therapy. Digestion. 2006;73 Suppl 1:94-101. Epub 2006 Feb 8.

12. Han MK, Hyzy R. Advances in critical care management of hepatic failure and insufficiency. Crit Care Med. 2006 Sep;34(9 Suppl):S225-31. 
13. Iversen P, Hansen DA, Bender D, Rodell A, Munk OL, Cumming P, Keiding S. Portal hypertension. Curr Opin Gastroenterol. 2006 May;22(3):254-62.

14. Jover R, Rodrigo R, Felipo V, Insausti R, Saez-Valero J, Garcia-Ayllon MS, Suarez I, Candela A, Compan A, Esteban A, Cauli O, Auso E, Rodriguez E, Gutierrez A, Girona E, Erceg S, Berbel P, Perez-Mateo M. Brain edema and inflammatory activation in bile duct ligated rats with diet-induced hyperammonemia: A model of hepatic encephalopathy in cirrhosis. Hepatology. 2006 Jun;43(6):1257-66

15. Laleman W, Landeghem L, Wilmer A, Fevery J, Nevens F. Portal hypertension: from pathophysiology to clinical practice. Liver Int. 2005 Dec;25(6):1079-90.

16. Liu Q, Peng L, Du Y, Li M, Jia N, Zou HQ. A pilot study of using pure albumin as a dialysate in the treatment of liver failure. Zhongguo Wei Zhong Bing Ji Jiu Yi Xue. 2005 Oct;17(10):599-602.

17. Lai WK, Haydon G, Mutimer D, Murphy N. The effect of molecular adsorbent recirculating system on pathophysiological parameters in patients with acute liver failure. Intensive Care Med. 2005 Nov;31(11):1544-9.

18. Mas A. Hepatic encephalopathy: from pathophysiology to treatment. Digestion. 2006;73 Suppl 1:86-93. Epub 2006 Feb 8.

19. Malaguarnera M, Pistone G, Elvira R, Leotta C, Scarpello L, Liborio R. Effects of L-carnitine in patients with hepatic encephalopathy. World J Gastroenterol. 2005 Dec 7;11(45):7197-202

20. O'Neal H, Olds J, Webster N. Managing patients with acute liver failure: developing a tool for practitioners. Nurs Crit Care. 2006 Mar-Apr;11(2):63-8

21. Rinella ME, Sanyal A. Intensive management of hepatic failure. Semin Respir Crit Care Med. 2006 Jun;27(3):241-61.

22. Raghavan M, Marik PE. Therapy of intracranial hypertension in patients with fulminant hepatic failure. Neurocrit Care. 2006;4(2):179-89

23. Shawcross D, Jalan R. . The pathophysiologic basis of hepatic encephalopathy: central role for ammonia and inflammation. Cell Mol Life Sci. 2005 Oct;62(1920):2295-304.

24. Takikawa Y, Endo R, Suzuki K, Fujiwara K, Omata M; Fulminant Hepatitis Study Group of Japan. Prediction of hepatic encephalopathy development in patients with severe acute hepatitis. Dig Dis Sci. 2006 Feb;51(2):359-64.

25. Weissenborn K, Giewekemeyer K, Heidenreich S, Bokemeyer M, Berding G, Ahl B. Attention, memory, and cognitive function in hepatic encephalopathy. Metab Brain Dis. 2005 Dec;20(4):359-67.

26. Vaquero J, Butterworth RF. The brain glutamate system in liver failure. J Neurochem. 2006 Aug;98(3):661-9. Epub 2006 Jun 12.

27. Vaquero J, Fontana RJ, Larson AM, Bass NM, Davern TJ, Shakil AO, Han S, Harrison ME, Stravitz TR, Munoz S, Brown R, Lee WM, Blei AT. Complications and use of intracranial pressure monitoring in patients with acute liver failure and severe encephalopathy. Liver Transpl. 2005 Dec;11(12):1581-9. 
Seminar 7

\section{HEPATORENAL SINDROM}




\section{TORIFI}

Hepatorenal sindrom (HRS) qaraciyərin kəskin və xronik xəstəliklərinin böyrəklərdə törətdiyi funksional dəyişiklik olub, qlomerulyar filtrasiyada azalma, $\mathrm{Na}+$ və su tutulmasında isə artma ilə xarakterizə olunur. Böyrəklərdə xəstəlik, morfoloji dəyişiklik, nefrotoksik təsir və ya böyrək funksiyasını pozan amillər (hipovolemiya, obstruksiya və s.) olmur. Belə xəstələrin böyrəyini qeyri-sirrotik xəstələrə köçürdükdə normal fəaliyyətini bərpa edir.

HRS subklinik, xronik (kreatinin $>1,5 \mathrm{mq} / \mathrm{dl}$, klerens $<40 \mathrm{ml} /$ dəq, sidik ifrazı $<500$ $\mathrm{ml} /$ gün, hiponatremiya $<130 \mathrm{mEq} / \mathrm{L}$, sidikdə $\mathrm{Na}+$ azalmas $<10 \mathrm{mEq} / \mathrm{L}$ ) və kəskin böyrək yetməzliyi (kreatinin $>3 \mathrm{mq} / \mathrm{dl}$, klerens $<20 \mathrm{ml} /$ dəq.) şəklində görünə bilir. Sirrozda HRS təxminən 20-50\% hallarda rast gəlir.

\section{ETIOLLOGIYYASI}

HRS törədən səbəbləri iki qrupa ayırmaq olar: əsas və ă̆ırlaşdırıcı. Osas səbəblər adlandırılan qaraciyərin kəskin və xroniki xəstəlikləri bilavasitə HRS-ə səbəb olan və ya buna meyil yaradan amillərdir. Xüsusən, kəskin qaraciyər yetməzliyi, sirroz, mexaniki sarılıq, portal hipertenziya HRS-in ən çox rast gələn səbəbləridir. Ağırlaşdırıcı amillər isə, subklinik və ya stabil seyr edən xroniki HRS-i dərinləşdirərək kəskin formaya keçməsinə səbəb olur. Spontan bacterial peritonit, infeksiyalar, mədəbağırsaq qanaxmaları, refrakter assit, böyük həcmli parasentezlər, portal vena trombozu HRS-i ağırlaıdıran səbəblərdir.

\section{PATOGENEZI}

Hesab edilir ki, hepatorenal sindroma xas olan iki əsas funksional böyrək dəyişikliyinin (filtirasiya azalması və reabsorbsiya artması) əsasında iki önəmli mexanizm durur: böyrək arteriyalarının spazmı va böyrəkdaxili tənzimin pozulması (Şəkil 1). 


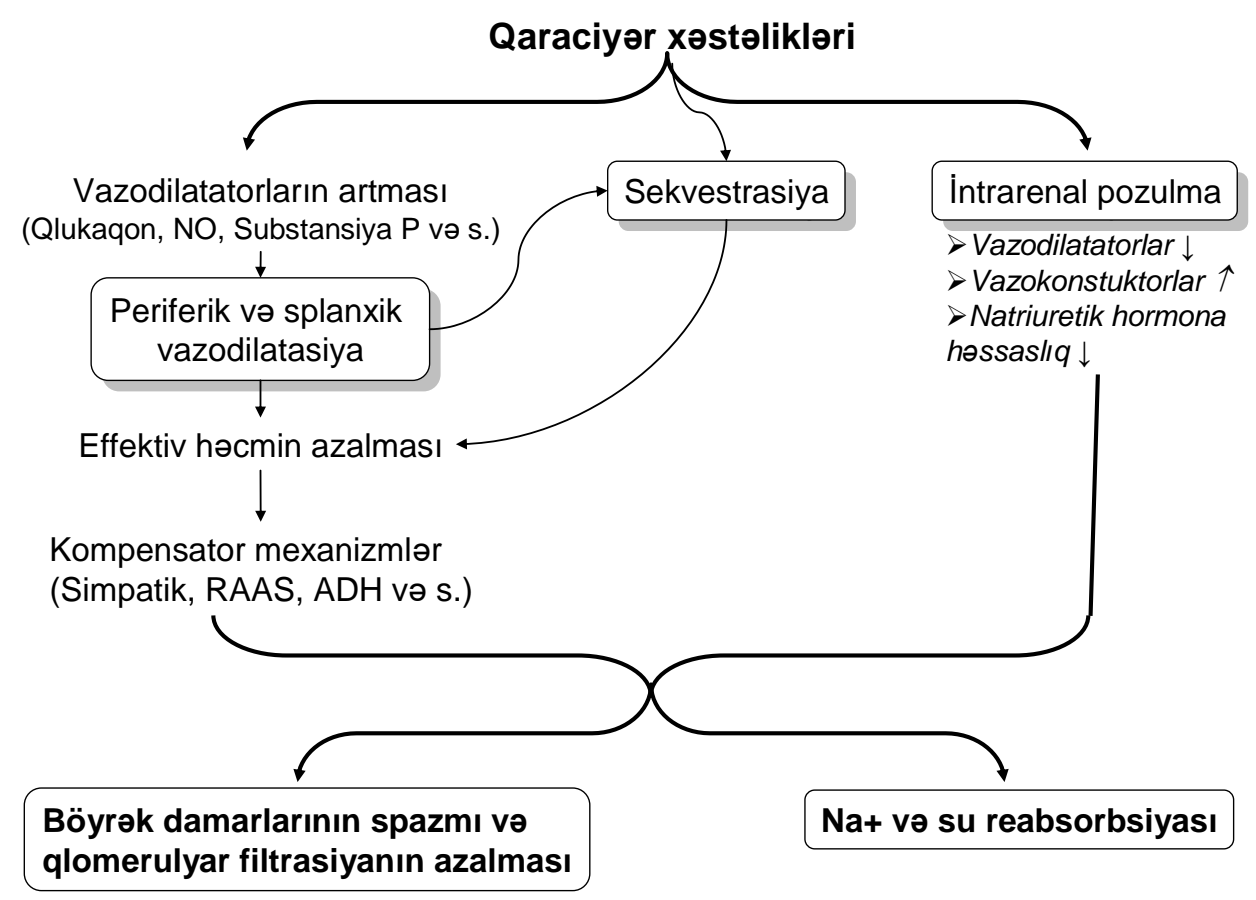

Şəkil 1. Hepatorenal sindromun patogenezi

\section{Böyrək arteriyalarının spazmı}

Böyrək arteriyalarının spazmını ümumi və yerli mexanizmlər törədə bilir. Məlumdur ki, qaraciyər xəstəliklərində vazodilatator maddələrin (qlukaqon, nitric oksid-NO, substansiya, P, və s.) zərərsizləşməsi azalır ki, bu da periferik vazodilatasiyaya səbəb olur. Digər tərəfdən portal hipertensiya və assit sekvestrasiyaya səbəb olur. Ümumi vazodilatasiya və periton boşluğunda sekvestrasiya dövredən qanın həcminin azalmasına səbəb olur. Bu isə, kompensator mexanizmləri aktivləşdirərək (simpatik sistem, renin - anqiotenzin -aldesteron, antidiuretik hormon-ADH və s.) böyrək damarlarında spazm törədir, filtrasiyanı azaldır və reabsorbsiyanı artıraraq effektiv həcmi bərpa etməyə çalışır.

Mexaniki sarllıqda atrial natriuretik pepdidin artması və ekstrasellular mayenin azalması (2-3 həftə ərzində 3-4\%, təxminən $3000 \mathrm{ml}$ ) digər faktorlarla birlikdə dövredən qan həcminin ciddi şəkildə azalmasına gətirib çıxarır.

Qan həcminin azalmasından başqa, böyrəkdə damar spazmı törədən ikinci mexanizm böyrəkdaxili tənzimin pozulmasıdır. Yerli vazokonstruktor maddələr olan 
prostoqlandin (PG-E2) və endotelinin (ET-1) vazodilatatorlara (NO) nəzərən artmas1 renal spazma şərait yaradır.

\section{$\mathrm{Na}+$ və su reabsorbsiyasında artma}

$\mathrm{Na}+$ və su reabsorbsiyasında artma həm ümumi amillərin, xüsusən aldesteron və ADH-ın, həm də, böyrəkdaxili həssaslığının dəyişməsi ilə əlaqələndirilir. Hepatorenal sindromda natriuretik hormonun artmasina baxmayaraq $\mathrm{Na}+$ ifrazı artmır. Hesab edilir ki, bu böyrəklərdə natriuretik hormona həssaslığın azalması ilə əlaqədardır.

Qeyd etmək lazımdır ki, effektiv həcmin azalması, böyrəkdə vazokonstruksiya kimi patogenetik mexanizmlər xronik qaraciyər xəstəliklərində önəmli rol oynayır. Kəskin qaraciyər xəstəliklərində isə, bunlarla yanaşı UİS və endotelial zədələnmə prosesləri də böyrək yetməzliyinin baş verməsinə səbəb olur.

\section{GEDİŞi Və KLİNIKASI}

Hepatorenal sindromun üç gediş forması qeyd edilir: subklinik, kaskin va xroniki. Subklinik forma xronik qaraciyər xəstəliklərində rast gəlir və kreatinin səviyyəsi və klirensinin normal olmasına baxmayaraq, Dopler USM ilə böyrək damarlarında spazm təyin olunur.

Kaskin forma va ya I tip HRS, böyrək funksiyasının kəskin azalması ilə xarakterizə olunur. $\mathrm{Bu}$ forma kəskin xəstəliklərdə və ya xroniki xəstəliklərdə ağırlaşdırıcı amillərin təsiri nəticəsində meydana gərir. Sidik ifrazının kəskin azalması, azotemiya, kreatinin artması $(>3 \mathrm{mq} / \mathrm{dl}-300 \mathrm{mmol} / \mathrm{l})$, klirens azalması $(<20 \mathrm{mml} / \mathrm{l})$ şəkilində ortaya ç1xır. Qaraciyər transplantasiyası edilməzsə I tip HRS-in proqnozu pisdir və adətən 2 həftə ərzində xəstə itirilir.

Xroniki forma və ya II tip HRS-də böyrək funksiyalarının azalması daimi xarakterlidir. Kreatinin artması $(>1,5 \mathrm{mq} / \mathrm{dl})$, klerensin azalması $(<40 \mathrm{ml} / \mathrm{dəq})$, hiponatremiya $(<130 \mathrm{mEq} / \mathrm{L})$ və sidikdə $\mathrm{Na}+$ azalması $(<10 \mathrm{mEq} / \mathrm{L})$ əlamətləri görünür. $\mathrm{Bu}$ forma diuretiklərə cavab versə də, xəstələrin yaşama müddətini qısaldır ( 1 illik yaşamı 20\%, 5 illik yaşamı isə, 39\% azaldır). Ağırlaşdırıcı faktorlar bu formanı dərinləşdirərək kəskin tipə çevirə bilir. 
Şübhə

Xronik qaraciyər xəstəlikləri

Kreatinin $>1.5 \mathrm{mq} / \mathrm{dl}$

$\mathrm{Na}+<130 \mathrm{mEq} / \mathrm{l}$

Kiçik qaraciyər

Müqavimət indeksinin artması

\section{Diqanostik kriteriyalar}

Әsas kriteriyalar (mütləq)

Qaraciyər xəstəliyi, yetməzliyi və/və ya portal hipertenziya var

Kreatinin $>1.5 \mathrm{mq} / \mathrm{dl}$ və ya klirens $<40 \mathrm{ml}$

Nefrotoksik dərmanlar, şok, infeksiya və ya hipovolemiya yoxdur

Proteinuriya $<500 \mathrm{mq} / \mathrm{dl}$ və böyrək xəstəliyi yoxdur

Diuretiksiz və 1,5 I izotonik maye köçürüldükdən sonra yaxşılaşma yoxdur

Olavə kriteriyalar (varlığı təsdiq edir, yoxluğu inkar etmir)

Sidik miqdarı $<500 \mathrm{ml}$

Sidikdə $\mathrm{Na}+<10 \mathrm{mEq} / \mathrm{l}$

Sidik osmolyarlığı > plazma osmolyarlığı

Sidikdə ertrositlər $<10 \mathrm{~g} / \mathrm{s}$

Plazma $\mathrm{Na}+<130 \mathrm{mEq} / \mathrm{l}$

\section{Şəkil 2. Hepatorenal sindromun diaqnostikası}

\section{DİAQNOZU}

Qaraciyər xəstəliyi və PH-olan xəstələrdə böyrək funksiyalarını yoxlamaq və HRS-in olub olmadığını müəyyənləşdirmək lazımdır. Xususən, sidik ifrazının azalması HRSə şübhə yaradan ən vacib klinik əlamətdir.

HRS-in əsas göstəricisi qanda kreatinin artmasıdır ( $>1,5 \mathrm{mq} / \mathrm{dl})$. HRS-in diaqnozunu dəqiqləşdirmək üçün böyük (olması mütləqdir) və kiçik (olması şərt deyil, lakin olmaması şübhə yaradır) kriteriyalar təklif edilmişdir (Şəkil 2)

Qaraciyər xəstəliyinin və qlomerulyar filtirasiyada azalmanın varlığı ilə yanaşı böyrəkdə xəstəlik və zədələnmənin olmaması HRS-in böyük kriteriyaları sayılır.

\section{MÜALICOSİ}

HRS-in müalicəsində ilk hadəf asas səbəbin va ă̆ırlaşdırıcı amillarin aradan qaldırllmasıdır. İkinci hadəf böyrək damarlarının genişləndirilməsi vo reabsorbsiyanın azaldılmasıdır. 


\section{Prinsip: \\ Renal vazodilatasiya \\ Splanxik vazokonstruksiya +həcm artırma \pm renal vazodilatator}

Nefrotoksik dərmanlar, infeksiya və

s. aradan qaldırılır

1,5 I izotonik məhlul verilir

Terlipressin + albumin verilir

$\mathrm{N}$-asetilsistein verilir

Dopamin + albumin + furosemid başlanır

Parasentez edilir

TiPS, Tx, Hemofiltrasiya və ya dializ düşünülür

Tәcili Qc Tx

\section{Şəkil 3. Kəskin (I tip) hepatorenal sindromun müalicəsi}

Bunun üçün müxtəlif vasitələr - qan həcmini artırma, sistemik vazokonstuksiya, renal vazodilatatorlar, diuretiklər və s. tətbiq edilir. Әvəzləyici müalicə-dializ son seçim tədbiridir.

Seçiləcək müalicə alqoritmi HRS-in gediş formasindan asılı olara dəyişir.

Kəskin (I tip) HRS-də ilk növbədə ağırlaşdırıcı amilləri aradan qaldırmaq gərəkir: nefrotoksik dərmənların kəsilməsi, həcmin bərpası-1500 ml izotonik maye köçürmə, infeksiya və xolestazın müalicəsi, qanaxmanın dayandırılması və s. (Şəkil 3). Bu tədbirlər faydasız olduqda əsas səbəbin müalicəsinə başlamaq lazımdır. Qc transplantasiyası kəskin qaraciyər yetməzliyi və sirrozda HRS-in ən effektiv müalicəsidir. Mexaniki sarılıqda böyükhəcimli infuziyalar (3000-4000 ml) böyrəyi müvəqqəti yaxşılaşdırsa da, effektiv düzəlmə ödün bağırsağa keçişindən 48 saat sonra baş verir.

Təcili Qc Tx mümkün olmayan hallarda ikinci hədəf - böyrək damarlarını genişləndirmə tədbirləri başlanır. Bu məqsədlə həcmi artırma, periferik (splanxik) vazokonstruksiya və renal vazodilatasiya həyata keçirilir. 


\title{
Prinsip: \\ $\mathrm{Na}+$ və suyu azaltma \\ Diet + Diuretik
}

\author{
Yataq rejimi \\ $\mathrm{Na}+$ azaldılması $(<1 \mathrm{q})$ \\ Sprinolakton 100-400 mq/gün \\ Furosemid 160 mq/gün qədər (müvəqqəti) \\ Ağırlaşdırıcı amillərin aradan qaldırıması \\ Qc Tx
}

\section{Şəkil 4. Xroniki (II tip) hepatorenal sindromun müalicəsi}

Həcmi artırmaq üçün maye köçürməklə (1500 ml izotonik məhlul) yanaşı osmotik-onkotik dərmanlar (mannitol, albumin) tətbiq edilir. HRS-də iki qrup vazokonstruktorlar itifadə olunur: umumi (adrenomimetiklər olan dopamin, noradrenalin) və yerli (vasopressin analoqları olan terlipressin vo ornipressin). Terlipressin+albumin və dopamin+albumin+furosemid birləşməsi və ən çox tovsiyə edilən kombinasiyalardır. Bunlara renal vazodilatator kimi $\mathrm{N}$-asetilsistein və pentoksifillin də əlavə edilə bilər. Bu tədbirlərə baxmayaraq, böyrək fəaliyyəti bərpa olunmazsa, portal hipertenziya və gərgin assiti olan xəstələrdə QDPKYY edilir ki, bu da glomerulyar filtirasiyanı 75\% yaxşılaşdıra bilir. Digər hallarda son vasitə kimi hemodializ tətbiq edilə bilər. Lakin, digər kəskin böyrək yetməzliklərindən fərqli olaraq I tip HRS-də hemodializ yüksək evvektiv deyil və ağırlaşmalara səbəb ola bilir.

İkinci tipdə-xroniki seyr edən HRS-də əsas müalicə prinsipi su və $\mathrm{Na}+$ reabsorbsiyasını azaltmaq vo ağırlaşdırıcı amillərin profilaktikasıdir(Şəkil 4). Aldesteron antoqonisti sprinolakton (100-400 mq/gün) bu məqsədlə ən çox istifadə edilən dərmandır. Bu effect vermədikdə furosemid (160 mg həftədə 2-3 dəfə) də əlavə edilə bilər.

Kəskinləşmənin profilaktikası məqsədi ilə ağırlaşdırıcı amillərin qarşısını vaxtında almaq vacib şərtdir. Böyük parasentezlərdə (>5000 ml) böyrək yetməzliyinin profilaktikası üçün albumin və ya dekstran (çıxarılan hər litir assitə 8 q) köçürmək lazımdır. Mexaniki sarılıqda erkən biliar drenaj, əməliyyatönü infuziyalar (3000-4000 ml), furosemid və oral ursodezoksixol turşüsü HRS-i önləyə bilir. Refrakter 
assitdə QDPKYY assiti azaltmaqla yanaşı böyrək fəaliyyətini də yaxşılaşdırır. Spontan bacterial peritonitin profilaktikası üçün (assitdə albumin $2 \mathrm{mq} / \mathrm{dl}$-dən aşağı olarsa) sefalosporin antibiotiklərinin istifadəsi həm də, kəskin böyrək yetməzliyinin profilaktikasıdır.

\section{Osas adobiyyat}

1. Ăgayev B.A. Corrahi Xəstəliklər. Bakı 2001

2. Blumgart LH. Surgery of the Liver, Biliary tract and Pancreas. 4th ed. 2006

3. Cuschieri SA. Disorders of the liver. Module 10, p 321-374. in Cuschieri SA, Steel RJ, Moossa AR. Essentiale Surgical practice.. $4^{\text {th }}$ ed. 2002

4. Feldman M, Friedman LS, Sleisenger MH. Sleisenger and Fordtran`s Gastrointestinal and Liver diseases. $7^{\text {th }}$ ed. Vol II, 2002.

5. Modern Surgical Care. 2 ed. Vol I, 1998

6. Oxford textbook of Surgery V.1, 2004

7. Rob and Smith's Hepatobiliary and Pancreatic Surgery. 2. ed. 1996

8. Sabiston. Textbook of Surgery 17 ed., 2006, p.1112-1143

9. Timothy DS, Steven AC. Liver. Chapter 30, p 1139-1186. in Schwartz"s Principles of Surgery18th ed., 2004

10. Thomas JN, Gordon AH. Pathophysology. International edition. 3th ed. P 369-396, 2004

11. Sherlock S, Dooley J. Disease of the liver and biliary tract. 11-th ed. 2001

12. Sultanov H.A. Corrahi Xastaliklar. Bakı 2000

13. Surgical Anatomy and Embriology. Surgical Clinics of North America Vol 73, no 4, 1993

14. William RJ. Liver and Portal venouse system. In: Gerard MD, Lawrence WW, Current Surgical Diagnosis and Treatment. $12^{\text {th }}$ edition, 2006, p 539-572

15. Zudema GD. Shackelford's Surgery of Alimentary tract, Vol III, 5th ed, 2006

\section{Olavo adobiyyat}

1. Arroyo V, Terra C, Gines P. New treatments of hepatorenal syndrome. Semin Liver Dis. 2006 Aug;26(3):254-64.

2. Bruha R, Skupiny C, Balihar K, Drastich P, Hulek P, Lata J, Petrtyl J, Prochazka V, Spicak J, Vanasek T, Volfova M, Zdenek P; Czech Hepatology Society; J E Purkinje Czech Medical Society. Diagnostics and therapy of hepatorenal syndrome. Recommendations of of the working group on portal hypertension of the Czech Hepatology Society and the J. E. Purkinje Czech Medical Society. Vnitr Lek. 2006 Jun;52(6):649-50

3. Cardenas A, Gines P. Therapy insight: Management of hepatorenal syndrome. Nat Clin Pract Gastroenterol Hepatol. 2006 Jun;3(6):338-48.

4. Demirtas S, Can M, Yarpuzlu A. Hepatorenal syndrome. Clin Chem Lab Med. 2006;44(4):379-86.

5. Debray D, Yousef N, Durand P. New management options for end-stage chronic liver disease and acute liver failure: potential for pediatric patients. Paediatr Drugs. 2006;8(1):1-13.

6. Garcia-Tsao G. Portal hypertension. Curr Opin Gastroenterol. 2006 May;22(3):254-62

7. Neuhofer W, Pittrow D. Role of endothelin and endothelin receptor antagonists in renal disease. Eur J Clin Invest. 2006 Sep;36 Suppl 3:78-88.

8. Han MK, Hyzy R. Advances in critical care management of hepatic failure and insufficiency. Crit Care Med. 2006 Sep;34(9 Suppl):S225-31

9. Hansard PC, Manning RA, Haseeb MA, Salwen MJ. Hepatorenal syndrome: resolution of ascites by continuous renal replacement therapy in an alcoholic coinfected with hepatitis B, C, and human immunodeficiency viruses. Ann Clin Lab Sci. 2006 Winter;36(1):96-100.

10. Moreau R, Lebrec D. The use of vasoconstrictors in patients with cirrhosis: type 1 HRS and beyond. Hepatology. 2006 Mar;43(3):385-94.

11. Schepke M, Appenrodt B, Heller J, Zielinski J, Sauerbruch T. Prognostic factors for patients with cirrhosis and kidney dysfunction in the era of MELD: results of a prospective study. Liver Int. 2006 Sep;26(7):834-9.

12. Wong F. The use of TIPS in chronic liver disease. Ann Hepatol. 2006 Jan-Mar;5(1):5-15. 
Seminar 8

\section{SPLENOMEQALIYA VӘ PORTAL HIPERTENZIV QASTROPATIYA}




\section{SPLENOMEQALIYA}

PH-ın əlamət və ağırlaşmalarından biri də splenomeqaliya və hipersplenizmdir. Buna durğunluq splenomeqaliyası və ya Banti sindromu da deyilir. Splenomeqaliya "soltərəfli” (dalaq venası trombozu) PH-da daha bariz şəkildə ortaya çıxır.

Durğunluq splenomeqaliyasında $\mathrm{PH}$ və splenomeqaliya qüsurlu dövran yaradır: $P H$ splenomeqaliya töradir, splenomeqaliya is portal sistema qangalimi artıraraq PH-nı artırır (Şəkil 1). Belə vəziyyətdə PH-nın splenomeqaliya törətdiyi, yoxsa splenomeqaliyanın PH törətdiyini təyin etmək çətin olur. Bunu dəqiqləşdirmək üçün Qc və portal venanı yoxlamaq vacibdir. Qc və portal sistemində tıxanma olmayan hallarda hematoloji, infeksion və digər xəstəliklər inkar olunarsa birincili splenomeqaliya (tropik splenomeqaliya) qəbul edilə bilər.

Kəskin forma istisna olmaqla, adətən PH-da splenomeqaliya yavaş inkişaf edir.

Stabil seyr edən PH-da dalağın sürətlə böyüməsi limfomaya, qapı venası trombozuna və hepatosellular karsinomaya şübhə yaradır.

Qc və portal vena xəstəliklərində splenomeqaliya iki halda klinik problem təşkil edir: hipersplenizm vo modo varikoz qanaxmasında.

Hipersplenizm splenomeqaliya ilə yanaşı sitopeniyanın olmasıdır. Sitopeniya tək trombositopeniya $\left(<100 \times 10^{12} / \mathrm{l}\right)$, leykopeniya $\left(<4 \times 10^{9} / \mathrm{l}\right)$, anemiya $(\mathrm{Hb}<100 \mathrm{q} / \mathrm{l})$ şəklində və ya bunların birliyi ilə (di-, pansitopeniya) ortaya çıxa bilər.

Qc xəstəliklərində sitopeniya və ya mədə varikoz qanaxması yoxdursa, yalnız splenomeqaliyaya görə hər hans1 müdaxiləyə ehtiyac yoxdur. Hipersplenizm və ya mədə varikoz qanaxması olan hallarda isə, splenektomiyadan çəkinmək lazımdır. Çünki, bu xəstələrdə adətən dalaq normal olur, hipertenziya aradan qalxarsa dalaq kiçilə bilir və splenektomiya ilə nəinki, PH aradan qalxmır, hətta ciddi ağırlaşmalar meydana gələ bilir. Ona görə də, bu xəstələrdə dalağı qorumaq gərəkir və aşağıdakı alternativlər tətbiq edilə bilər:

- Böyümə faktorları istifadəsi

- Hissəvi dalaq embolizasiyası

- Dalaq arteriyası stendlənməsi

- Distal spleno-renal şunt 


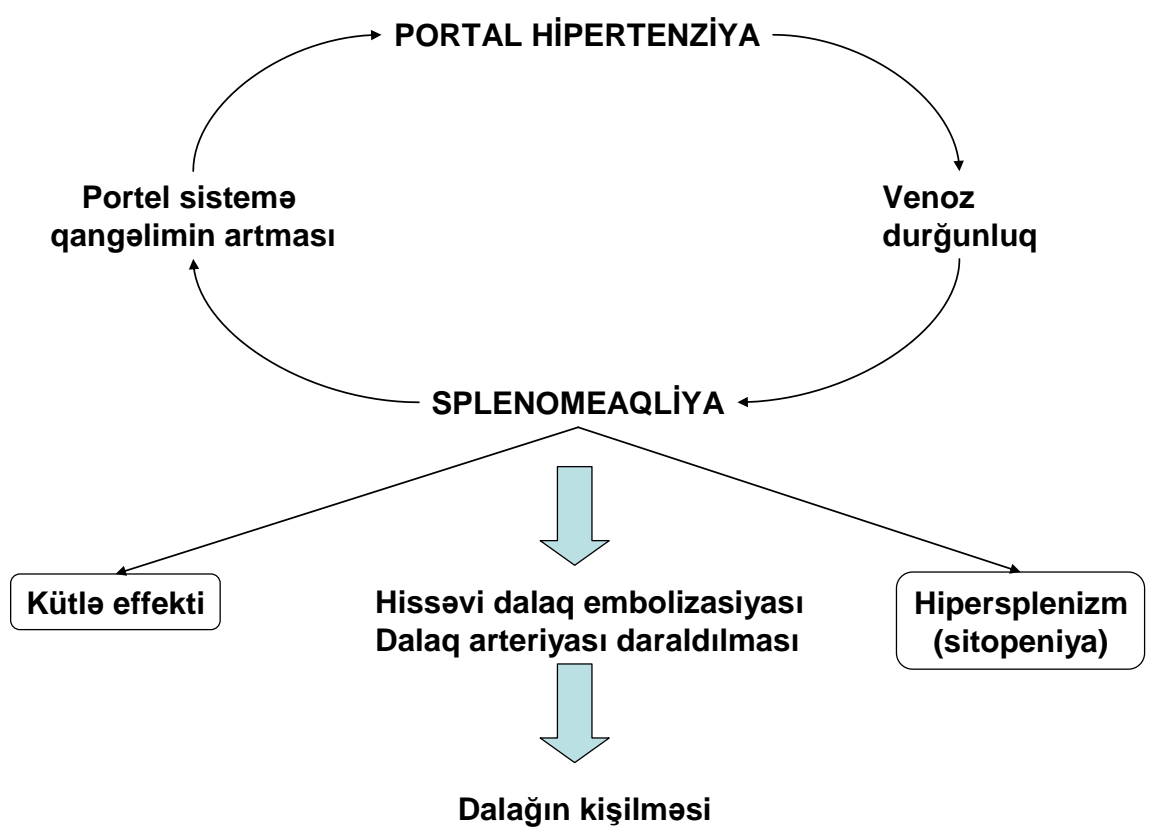

Şəkil 1. PH-da splenomeqaliyanın patogenezi və nəticələri

Portal və splenik vena trombozlarında hipersplenizm və ya mədə varikoz qanaxması varsa hissəvi dalaq embolizasiyası, dalaq arteriyasının stendlə daraldılması və ya splenektomiya edilə bilər.

Qeyd etmək lazımdır ki, splenomeqaliyası olan, lakin hipersplenizmi və ya mədə varikoz qanaxması olmayan xəstələrdə profilaktik əməliyyatlar tövsiyə edilmir.

\section{PORTAL HIPERTENZIV QASTROPATIYA (PHQ)}

Mədə varisindən başqa PH-nın mədədə törətdiyi digər xarakterik dəyişiklik portal hipertenziv qastropatiya (PHQ) adlanan xəstəlikdir. Uzunmüddətli venoz durğunluğa bağlı meydana gələn bu patologiyada selikli qişada ödem, distrofiya, venoz genişlənmə, selikaltı iltihabi infiltrasiya, hemorragiya, hemosideroz kimi dəyişikliklər görünür. Hətta eroziya və xoralar da ola bilər və bunlar kəskin və xroniki qanaxma da törədə bilər. 
PHQ klinik olaraq asimptomatik şəkildə ola bilər, dispeptik əlamətlərlə (qarında yeməkdən sonra və ya yeməksiz ağrı, köp, rahatsızlıq, gəyirmə) və ya ağırlaşma qanaxma əlamətləri ilə ortayaçıxa bilər. Kliniki olaraq PHQ diaqnozunu qoymaq çətin olur və diaqnoz adətən endoskopik müayinədə təyin edilir. Endoskopik olaraq PHQnin xarakterik əlamətləri, və müxtəlif formaları var (torşəkilli selikli qişa, hemorragiya nöqtələri və s.).

PHQ-nin osas müalicəsi PH-1 effektiv azaltmaqdır. Təcrübə göstərir ki, transplantasiya və dekompressiv əməliyyatlardan sonra qastropatiya ciddi şəkildə geriləyir.

Hazırda PHQ-nin digər spesifik müalicəsi yoxdur. Qastritlərdə tətbiq edilən standart müalicələr (antisekretor, anti-Helikobakter pillory) patologiyanı ciddi dəyişdirmir. PHQ adətən qanaxma törətdikdə ciddi klinik problem təşkil edir. Diaqnozu endoskopiya ilə dəqiqləşən qastropatiya qanaxmasında müalicə əsasən konservativ aparılır. PH azaldan dərmanlarla yanaşı yerli bürüyücü antasidlərin istifadəsi çox vaxt faydalı olur. Xüsusən, $60 \mathrm{ml}$ sukralfat suspenziyasını 4-6 dəfə mədəyə yeridilməsi qanaxmanı əksər hallarda dayandırır.

\section{Osas ədəbiyyat}

1. Ağayev B.A. Corrahi Xəstəliklər. Bakı 2001

2. Blumgart LH. Surgery of the Liver, Biliary tract and Pancreas. 4th ed. 2006

3. Cuschieri SA. Disorders of the liver. Module 10, p 321-374. in Cuschieri SA, Steel RJ, Moossa AR. Essentiale Surgical practice.. $4^{\text {th }} \mathrm{ed} .2002$

4. Feldman M, Friedman LS, Sleisenger MH. Sleisenger and Fordtran's Gastrointestinal and Liver diseases. $7^{\text {th }}$ ed. Vol II, 2002.

5. Modern Surgical Care. 2 ed. Vol I, 1998

6. Oxford textbook of Surgery V.1,2004

7. Rob and Smith's Hepatobiliary and Pancreatic Surgery. 2. ed. 1996

8. Sabiston. Textbook of Surgery 17 ed., 2006, p.1112-1143

9. Timothy DS, Steven AC. Liver. Chapter 30, p 1139-1186. in Schwartz"s Principles of Surgery18th ed., 2004

10. Thomas JN, Gordon AH. Pathophysology. International edition. 3th ed. P 369396, 2004

11. Sherlock S, Dooley J. Disease of the liver and biliary tract. 11-th ed. 2001

12. Sultanov H.A. Carrahi Xastaliklar. Bak1 2000

13. Surgical Anatomy and Embriology. Surgical Clinics of North America Vol 73, no 4, 1993 
14. William RJ. Liver and Portal venouse system. In: Gerard MD, Lawrence WW, Current Surgical Diagnosis and Treatment. $12^{\text {th }}$ edition, 2006, p 539572

15. Zudema GD. Shackelford's Surgery of Alimentary tract, Vol III, 5th ed, 2006

\section{Olavə ədəbiyyat - Splenomeqaliya}

1.

2. Chava SP, Pal S, Ghatak S, Kumar R, Sahni P, Chattopadhyay TK.

Splenectomy and proximal lieno-renal shunt in a factor five deficient patient with extra-hepatic portal vein obstruction. BMC Surg. 2006 May 19;6:7.

3. Colmegna I, deBoisblanc BP, Gimenez CR, Espinoza LR. Slow development of massive splenomegaly, portal and pulmonary hypertension in systematic lupus erythematosus: can nodular regenerative hyperplasia of the liver explain all these findings? Lupus. 2005;14(12):976-8.

4. Dib N, Konate A, Oberti F, Cales P. Non-invasive diagnosis of portal hypertension in cirrhosis. Application to the primary prevention of varices. Gastroenterol Clin Biol. 2005 Oct;29(10):975-87.

5. Goh SH, Tan WP, Lee SW. Clinical predictors of bleeding esophageal varices in the ED. Am J Emerg Med. 2005 Jul;23(4):531-5.

6. Luo HF, Wang HJ, Li B, Wang ZY. Diagnosis and management of extrahepatic portal vein aneurysm: a case report. Hepatobiliary Pancreat Dis Int. 2006 May;5(2):311-3.

7. Liu QD, Zhou NX, Zhang WZ, Wang MQ. Diagnosis and management of regional portal hypertension. Chin J Dig Dis. 2005;6(2):87-92.

8. Ohta M, Nishizaki T, Matsumoto T, Shimabukuro R, Sasaki A, Shibata K, Matsusaka T, Kitano S. Analysis of risk factors for massive intraoperative bleeding during laparoscopic splenectomy. J Hepatobiliary Pancreat Surg. 2005;12(6):433-7.

9. Pal S, Radhakrishna P, Sahni P, Pande GK, Nundy S, Chattopadhyay TK. Prophylactic surgery in non-cirrhotic portal fibrosis:is it worthwhile? Indian J Gastroenterol. 2005 Nov-Dec;24(6):239-42.

10. Petroianu A, De Oliveira AE, Alberti LR. Hypersplenism in schistosomatic portal hypertension. Arch Med Res. 2005 Sep-Oct;36(5):496-501.

11. Salihefendic N, Licanin Z, Zildzic M. Cavernous transformation of portal vein.

Med Arh. 2005;59(2):132-4.

12. Wang JT, Zhao HY, Liu YL. Portal vein thrombosis. Hepatobiliary Pancreat Dis Int. 2005 Nov;4(4):515-8.

13. Zapata-Colindres JC, Montano-Loza A, Zepeda-Gomez S, Uscanga L. Predictive factors for portal hypertension in patients with primary sclerosing cholangitis.

Gastroenterol Hepatol. 2006 Jan;29(1):7-10. 


\section{Olavə ədəbiyyat - PHQ}

1. De Palma GD, Rega M, Masone S, Persico F, Siciliano S, Patrone F, Matantuono L, Persico G. Mucosal abnormalities of the small bowel in patients with cirrhosis and portal hypertension: a capsule endoscopy study. Gastrointest Endosc. 2005 Oct;62(4):529-34

2. Karajeh MA, Hurlstone DP, Stephenson TJ, Ray-Chaudhuri D, Gleeson DC. Refractory bleeding from portal hypertensive gastropathy: a further novel role for thalidomide therapy? Eur J Gastroenterol Hepatol. 2006 May;18(5):545-8.

3. Rana SS, Bhasin DK, Jahagirdar S, Raja K, Nada R, Kochhar R, Joshi K. Is there ileopathy in portal hypertension? J Gastroenterol Hepatol. 2006 Feb;21(2):392-7.

4. Sarwar S, Khan AA, Alam A, Butt AK, Shafqat F, Malik K, Ahmad I, Niazi AK. Effect of band ligation on portal hypertensive gastropathy and development of fundal varices. J Ayub Med Coll Abbottabad. 2006 JanMar;18(1):32-5.

5. Yuksel O, Koklu S, Arhan M, Yolcu OF, Ertugrul I, Odemis B, Altiparmak E, Sahin B. Effects of esophageal varice eradication on portal hypertensive gastropathy and fundal varices: a retrospective and comparative study. Dig Dis Sci. 2006 Jan;51(1):27-30. 
Seminar 9

ANADANGӘLMӘ HEPATIK

FIBBROZ 


\section{FİBROPOLIKISTIK XəSTӘLIKLӘR}

Fibropolikistik xəstəlik və ya sistik fibroz anadangəlmə xəstəlikdir və genetik dəyişiklik nəticəsində axacaq sistemi embrional inkişafdan qalır (duktal malformasiya). Xəstəlik orqanizmin ümumi xəstəliyi hesab olunur və bir və ya bir neçə orqanda özünü göstərə bilir. Đn çox ağciyərdə, MAV-da, qaraciyər və öd yollarında ortaya çıxır. Xəstəliyin xarakterik morfoloji əlaməti olan duktal malformasiya kistlər və fibroz şəkilində ortaya çıxır. Xəstəliyin formasından asııı olaraq kist və ya fibroz, ya da hər ikisi üstünlük təşkil edə bilir.

Son tədqiqatlar göstərir ki, sistik fibroz xəstəliyi 7-ci xromosomda yerləşən və sistik fibroz transmembran requlyator (CFTR) adlanan genin mutasiyası nəticəsində meydana gəlir. CFTR geninin kodladığı protein hava yollarını, MAV axacağını, tər vəzilərinı, bağırsaqları, öd yollarını və toxum axacaqlarını örtən epitel hücüyrələrin membranlarında xlorid ionları ü̧̧ün kanal rolunu oynayır və $\mathrm{Na}+$ ionlarının hüceyrəyə giriş-çıxışını requlyasiya edir. CFTR-in mutasiyası nəticəsində xlorun hüceyrədən çıxışı azalır, $\mathrm{Na}+$ ionlarının isə hüceyrəyə absorbsiyası artır. Nəticədə epitel hüceyrələrindən axacağa su ifrazı da azalır ki, bu da sekretin qatılaşmasına, daşlaşmasına və axacaq sistemində durğunluğa səbəb olur. Axacaq sistemindəki durğunluq və keçməzlik nəticəsində orqanlarda iltihabi və infeksiyon ağırlaşmalar meydana gəlir (pnevmoniya, pankreatit, hidroadenit, sialadenit, sinusit, xolangit, mekonium keçməzliyi və s.)

Qaraciyər və öd yollarının fibropolikistik xəstəliyinin bir neçə morfoloji formaları var (Şəkil 1):

- Qaraciyər polikistozu

- Tək Qc kisti

- Anadangəlmə hepatik fibroz

- Karoli xəstəliyi

- Mikrohamartoma

- Xoledox kistləri

- Uşaqlarda xolestaz 


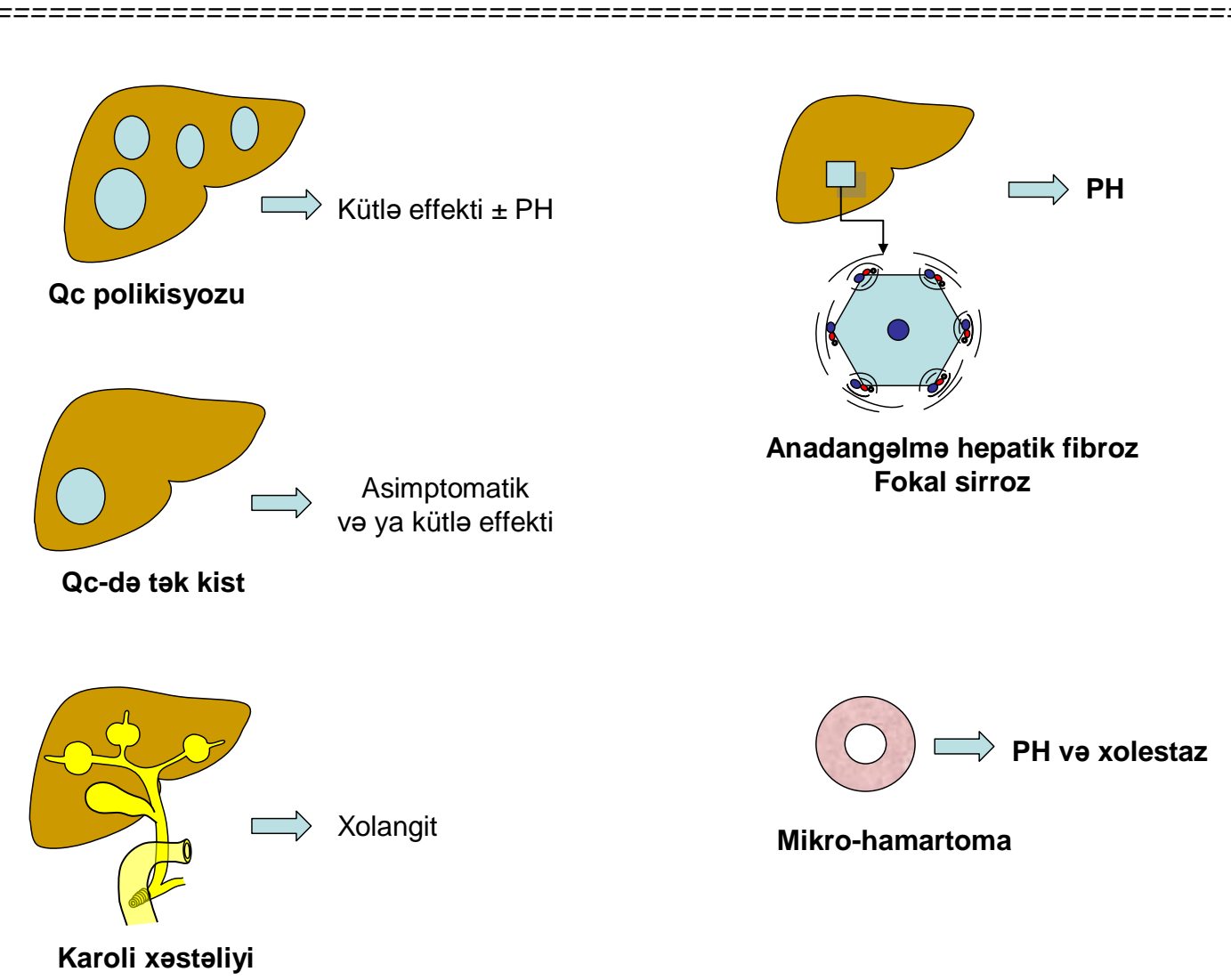

Şəkil 1. Qc və öd yollarının fibropolikistik xəstəlikləri

Bu xəstoliklər müxtəlif görünsələr do bəzi ümumi cəhətloro malikdirlor:

1. Bunların hamısı anadangəlmə genetik defektlə bağlı xəstəliklərdir və adətən eyni genin mütasiyası nəticəsində ortaya çıxırlar

2. Xəstəliklər digər orqanların fibropolikistik xəstəlikləri ilə birlikdə rast gələ bilir (məsələn, böyrək, pankreas, ağciyər polikistozu və s.)

3. Oksər xəstələrdə qaraciyər və öd yollarında iki və daha çox forma birlikdə rast gələ bilir.

4. Klinik olaraq bu xəstəliklər asimptomatik gedə bilər və ya dörd əlamətdən biri üstünlük təşkil edə bilər: kütlo effekti, xolestaz, xolangit, portal hipertenziya

5. Bu xəstəliklərdə bədxassəlilik potensialı var, ancaq çox aşağıdır.

6. Xəstəlik kiçik yaşlarda çox görünür, lakin böyük adamlarda da rastlanır.

\section{ANADANGOLMӘ HEPATIK FİBROZ}


Anadangəlmə hepatik fibroz fibrokistik xəstəliklərin digər növlərindən fərqləndiyi kimi, sirroz və nodulyar transformasiyalardan da fərqlənir (Şəkil 2).

AHF-də paycı̆̆ı̆ quruluşu qorunur və fibroz periportal bölgəni əhatə edir. Ona görə də, əksər hallarda Qc funksiyaları normal olur. Xəstəlik klinik olaraq əsasən portal hipertenziya ilə büruzə verir və PKYY-lar ciddi ensefalopatiya törətmir.

Nodulyar transformasiyada Qc paycıqlarını regenerativ düyünlər əvəz edir. $\mathrm{Bu}$ düyünlərdə paycıqlardan fərqli olaraq klassik arxitektonika pozulur. Öd kanalları, mərkəzi vena və sinusoid arxitektonikası olmur. Ona görə də, əksər hallarda hepatosellular disfunksiya müşahidə edilir.

Sirrozda isə, həm düyünlü transformasiya, həm də fibroz olmaqla yanaşı nekroz da müşahidə edilir.

AHF-dan fərqli olaraq kardiak fibrozda (durğunluq hepatopatiyası), fibroz perivenulyar bölgəni əhatə edir.

\section{Gedişi}

AHF ən çox uşaq yaşlarında üzə çıxsa da, böyüklərdə də görünə bilir. Әsasən PH əlamətləri ilə büruzə verir: assit, varikoz və hipersplenizm. Qc funksiyaları qorunduğu üçün ensefalopatiya və sarılıq çox nadirdir, hətta yanyol əməliyyatlarından sonra da az rast gəlir. Portal hipertenziyanı azaldılması bu xəstələrin yaşama müddətini xeyli artırır. Ovvəlcə də qeyd edildiyi kimi, AHF fibrokistik xəstəliyin digər formaları ilə birlikdə də rast gələ bilər.

\section{Klinikası və diaqnostikası}

Xəstəliyin əsas klinik əlaməti PH-dır. Bu özünü assit, varikoz qanaxması, splenomeqaliya şəklində göstərə bilər. Uşaqlarda, Qc və digər orqanlarında fibrokistik xəstəliyi olanlarda PH əlamətləri varsa, AHF ehtimalı çox yüksəkdir. Diaqnozu dəqiqləşdirmək üçün qaraciyər biopsiyası vacibdir. AHF üçün hepatosellular disfunksiya əlamətləri xarakterik deyil və adətən laborator göstəricilər normal olurlar. AHF diaqnozu qoyulmuş xəstələrdə qaraciyər göstəricilərində kəskin dəyişmə baş verərsə portal vena trombozu və viral hepatitin ortaya çıxdığını düşünmək olar. 


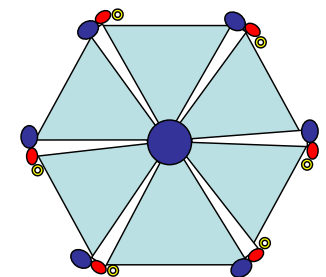

Qc paycığının normal arxitektonikası

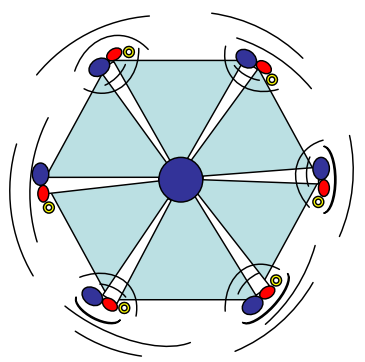

Periportal fibroz $A H F$

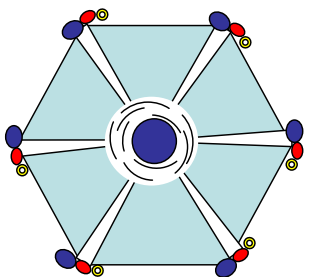

Perivenulyar fibroz Kardiak fibroz

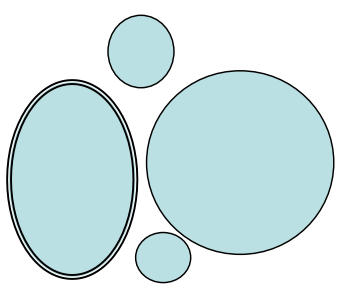

Paycığın düyünlü transformasiyası

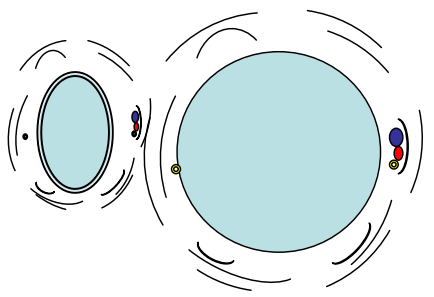

Düyün + fibroz

\section{Şəkil 2. Anadangəlmə hepatik fibrozun digər xəstəliklərdən diferensasiyası}

\section{Müalicəsi}

Xəstəlikdə dominant və həlledici sindrom $\mathrm{PH}$ olduğu üçün müalicə və proqnoz da $\mathrm{PH}$ 1n ağırlığından və müalicəyə cavabından asılıdır. Subklinik formada və konservativ tədbirlərlə nəzarətə alınan PH-da izləmə məsləhətdir. Ağırlaşma-qanaxma hallarında standart ilkin tədbirlərdə qanaxma dayandırılır. Təkrarlanan qanaxmalarda ən effektiv üsul PKYY hesab edilir. DSRYY ən çox tövsiyə olunanıdır. Lakin, digər YY-lar da eyni effektivliklə tətbiq oluna bilir. Hipersplenizmdə də PKYY lazım gəlir. Profilaktik yanyol isə, nəzarətdən çıxa bilən və ya müalicə mərkəzindən uzaqda yaşayan xəstələrdə və varikoz qanaxma risqi yüksək olanlarda tövsiyə olunur.

\section{Osas adobiyyat}

1. Ağayev B.A. Cərrahi Xəstəliklər. Bakı 2001

2. Blumgart LH. Surgery of the Liver, Biliary tract and Pancreas. 4th ed. 2006

3. Cuschieri SA. Disorders of the liver. Module 10, p 321-374. in Cuschieri SA, Steel RJ, Moossa AR. Essentiale Surgical practice.. $4^{\text {th }}$ ed. 2002 
4. Feldman M, Friedman LS, Sleisenger MH. Sleisenger and Fordtran's Gastrointestinal and Liver diseases. $7^{\text {th }}$ ed. Vol II, 2002.

5. Modern Surgical Care. 2 ed. Vol I, 1998

6. Oxford textbook of Surgery V.1,2004

7. Rob and Smith's Hepatobiliary and Pancreatic Surgery. 2. ed. 1996

8. Sabiston. Textbook of Surgery 17 ed., 2006, p.1112-1143

9. Timothy DS, Steven AC. Liver. Chapter 30, p 1139-1186. in Schwartz"s Principles of Surgeryl8th ed., 2004

10. Thomas JN, Gordon AH. Pathophysology. International edition. 3th ed. P 369396, 2004

11. Sherlock S, Dooley J. Disease of the liver and biliary tract. 11-th ed. 2001

12. Sultanov H.A. Carrahi Xastaliklar. Bak1 2000

13. Surgical Anatomy and Embriology. Surgical Clinics of North America Vol 73, no 4, 1993

14. William RJ. Liver and Portal venouse system. In: Gerard MD, Lawrence WW, Current Surgical Diagnosis and Treatment. $12^{\text {th }}$ edition, 2006, p 539572

15. Zudema GD. Shackelford's Surgery of Alimentary tract, Vol III, 5th ed, 2006

\section{Olavo adobiyyat}

1. Brancatelli G, Federle MP, Vilgrain V, Vullierme MP, Marin D, Lagalla R. Fibropolycystic liver disease: CT and MR imaging findings. Radiographics. 2005 May-Jun;25(3):659-70.

2. Desmet VJ. Cystic diseases of the liver. From embryology to malformations. Gastroenterol Clin Biol. 2005 Aug-Sep;29(8-9):858-60.

3. Giouleme O, Nikolaidis N, Tziomalos K, Patsiaoura K, Vassiliadis T, Grammatikos N, Papanikolaou V, Eugenidis N. Ductal plate malformation and congenital hepatic fibrosis Clinical and histological findings in four patients. Hepatol Res. 2006 Jun;35(2):147-50. Epub 2006 Mar 10

4. Housset C. Cystic liver diseases. Genetics and cell biology] Gastroenterol Clin Biol. 2005 Aug-Sep;29(8-9):861-9.

5. Luciani A, Kobeiter H, Zegai B, Anglade MC, Deux JF, Malhaire C, Rahmouni A. Imaging in congenital fibrocystic diseases of the liver. Gastroenterol Clin Biol. 2005 Aug-Sep;29(8-9):870-4.

6. Mazigh MS, Aloui N, Fetni I, Boukthir S, Aissa K, Sellami N, Bellagha I, Bousnina S, Barsaoui S. Congenital hepatic fibrosis in children. Report of 9 cases and review of the literature. Tunis Med. 2006 Mar;84(3):182-8.

7. Nelson LT. Cystic fibrosis. J Clin Gastroenterol. 2005 Apr: 39(4):307-17

8. Yonem O, Ozkayar N, Balkanci F, Harmanci O, Sokmensuer C, Ersoy O, Bayraktar Y. Is congenital hepatic fibrosis a pure liver disease? Am J Gastroenterol. 2006 Jun;101(6):1253-9. 
Seminar 10

\section{BADDİ-KİARİ SINDROMU}




\section{TORIFI}

Qaraciyərin venoz qan axınını ləngidən xəstəliklər tıxanma səviyyəsinə görə üç qrupa ayrilır (Şəkil 1).

Birinci qrup, sinus və kiçik venaların trombozu və sklerozu ilə xarakterizə olunan venokluziv xəstวliklar adlanır. Bu qrupda böyük venalar adətən açıq olur.

Böyük qaraciyər venalarının tıxanması nəticəsində meydana gələn venoz durğunluq Baddi-Kiari sindromu adlanır. Baddi-Kiari sindromunda qaraciyər venaları ilə yanaşı aşağı boş venada da tıxanma ola bilir.

Ekstrahepatik venostaz adlanan üçüncü qrupda isə, qaraciyərüstü aşağı boş venada qan axını əngəllənir. Sağ ürək yetməzliyi, konstruktiv perikardit, aşağı boş vena daralmaları (tromboz, membran, fibroz, şiş və s.) bu qrupa aiddir. Baddi-Kiari sindromundan fərqli olaraq, ekstrahepatik venostazda qaraciyər venaları nəinki açıq olur, hətta genişlənir.

$\mathrm{Bu}$ xəstəliklərin bəzi ümumi cəhətləri var. Venoz durğunluq nəticəsində hepatomeqaliya, assit və qaraciyər fibrozu bu qrupların ümumi cəhətləridir. Ekstrahepatik venostazda, xüsusən də, ürək yetməzliyinə bağlı durğunluqda (kardiak hepatomeqaliya) Qc funksiyaları ciddi pozulmur, sirroz inkişafı nadirdir, durğunluq ortadan qalxarsa Qc-də düzəlmə baş verə bilir. Sarılıq, xolestaz, ciddi Qc yetməzliyi venokluziv xəstəliklərdə daha çox rast gəlir. Baddi-Kiari sindromunda I seqment hipertrofiyası, eksudativ assit çox rast gəlir, kəskin qaraciyər yetməzliyi və sirroz meydana gələ bilir.

\section{SӘBӘBLӘRİ}

Baddi-Kiari sindromunu müxtəlif təbiətli xəstəliklər törədə bilir. Tromboz ən çox rast gələn tıxanma mexanizmidir. Şiş infiltrasiyası, iltihabi infiltrasiyalar və perihepatik fibroz venaları sıxaraq tıxanmaya səbəb ola bilər. Asiya ölkələrində Baddi-Kiari sindromunun ən çox rast gələn səbəbi kimi venalardakı membran (1/3-ində), avropa ölkələrində isə, mieloproliferativ xəstəliklər (polisitemiya vera, limfoma) bildirilir. Trombofiliya vəziyyətləri (protein $\mathrm{C}, \mathrm{S}$ defisiti, antilupus anticisimləri və s.) venoz tromboza səbəb ola bilir. Tromboza meyilli xəstələrdə kontraseptiv dərmanların istifadəsi də Baddi-Kiari sindromunu törədə bilər. 


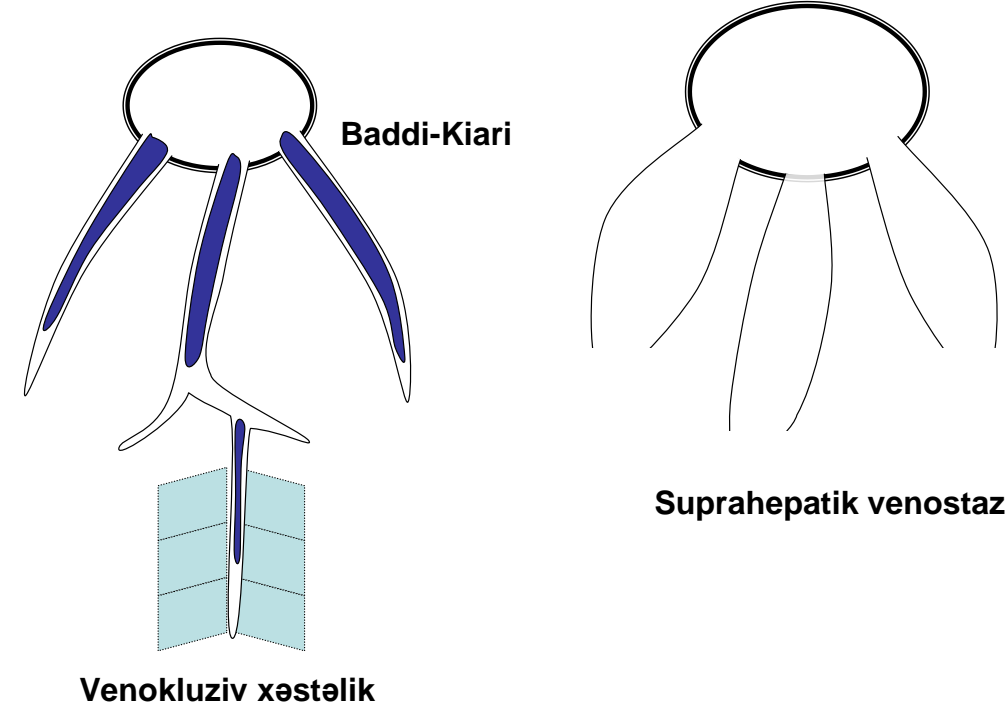

Şəkil 1. Qc-də venoz durğunluqların növləri

\section{PATOFIZİOLOGIYYASI}

Qc venalarının tıxanması nəticəsində meydana gələn venoz durğunluq Qc-də və orqanizmdə bir çox patoloji dəyişikliklərə səbəb olur (Şəkil 2). Hepatomeqaliya, ăgrı və assit ən erkən və xarakteritik dəyişiklərdir. Hepatomeqaliya erkən dövrdə venoz ödemlə, xronik fazada isə, fibrozla əlaqədar meydana gəlir. Ağrı Qlisson kapsulunun gərilməsi nəticəsində baş verir. Assit limfatik yüklənmə ilə əlaqədar ortaya çıxır. Qc venoz qanında protein çox olduğuna görə Baddi-Kiari sindromundakı assit eksudativ (proteini çox) tərkibli ola bilir. Venoz durğunluq qaraciyər parenximasında nekroza, hepatosellular disfunksiyaya gətirib çıxarır. Fulminant gedişdə geniş nekroza bağlı kəskin qaraciyər yetməzliyi meydana gəlir. Uzunmüddətli venoz durğunluq qaraciyərdə fibroza və sirroza səbəb olur. Qaraciyər venaları tutulduqdan sonra orqanın birinci seqmentindən başqa digər hissəsində venoz durğunluq yaranır. Birinci və VI seqmentin bəzi venaları birbasa boş venaya açıldıqları üçün bu seqmentlərin funksiyaları saxlanılır, hətta hipertrofiyaya məruz qalır. Bəzən I seqment yüksək dərəcədə hipertrofiya edərək aşağı boş venanı sıxa bilir. Qeyd etmək lazımdır ki, aşağı boş venada tıxanma olarsa I seqment hipertrofiyası meydana gəlmir.

\section{GEDİŞİ}


Baddi-Kiari sindromunun təbii gedişi ilk növbədə xəstəliyin səbəbindən asılıdır. Tromboza bağlı sindromda dörd gediş formasını qeyd etmək olar: fulminant, kəskin, xroniki va subklinik.

Fulminant forma massiv qaraciyər nekrozu və kəskin qaraciyər yetməzliyi əlamətləri (ensefalopatiya və koaqulopatiya və ya sarılıq ) ilə ortaya çıxır. Müalicə olunmazsa 23 həftə ərzində ölümə səbəb olur.

Kəskin forma hepatomeqaliya, ağrı və assit əlamətləri ilə ortaya çıxır və müalicə olunmazsa bir neçə həftə ərzində ölümə səbəb ola bilər.

Xroniki forma adətən müalicə olunmuş kəskin formanın nəticəsində meydana gəlir. Hepatomeqaliya və assit xarakterikdir. Fibroz mütləq rastlanır, bir neçə il ərzində sirroz inkişaf edə bilir.

Subklinik forma adətən ciddi əlamət vermir, təsadüfi müayinələrdə vaxtı I seqmentin hipertrofiyası görünəndə təyin edilir. Bu forma sirroza keçə bilər.

Beləliklə, Baddi-Kiari sindromu əksər hallarda proqressiv gedişli olub erkən ölümə və ya geriyədönməz xəstəlik olan sirroza gətirib çıxarır.

\section{KLİNİKASI}

Baddi-Kiari sindromunun klinik əlamətləri xəstəliyin səbəbi, trombozun yayılma dərəcəsi və gediş forması ilə sıx əlaqəlidir. Qarın ağrısı, ağrılı hepatomeqaliya və assit ən çox rastlanan əlamətlərdir.

Fulminant formada bu əlamətlər kəskin ortaya ç1xır və bir neçə gün ərzində kəskin qaraciyər yetməzliyi meydana gəlir: ensefalopatiya, koaqulopatiya, sarılıq, ağır ümumi vəziyyət. Bu xəstələr müalicə olunmazsa 2-3 həftə ərzində ölümlə nəticələnir.

Kəskin formanın ilk həftələrində əsas xəstəliyin əlamətləri üstünlük təşkil edir. Ağrı, hepatomeqaliya və assitlə yanaşı zəif sarılıq, ürəkbulanma əlamətləri görünür. Qc funksiyasının pozulması (koaqulopatiya, hipoalbuminemiya, yüksək sarılıq, ensefalopatiya) bu xəstələrdə tədricən inkişaf edir. Transaminazalarda artış qeyd edilir, assitin müayinəsində eksudativ xarakter tapılır. $\mathrm{Bu}$ xəstələr vaxtında müalicə edilməkdikdə tədricən inkişaf edən Qc yetməzliyi ölümə səbəb olur. Lakin son zamanlar aparılan müalicələr nəticələri yaxşılaşmışdır. 


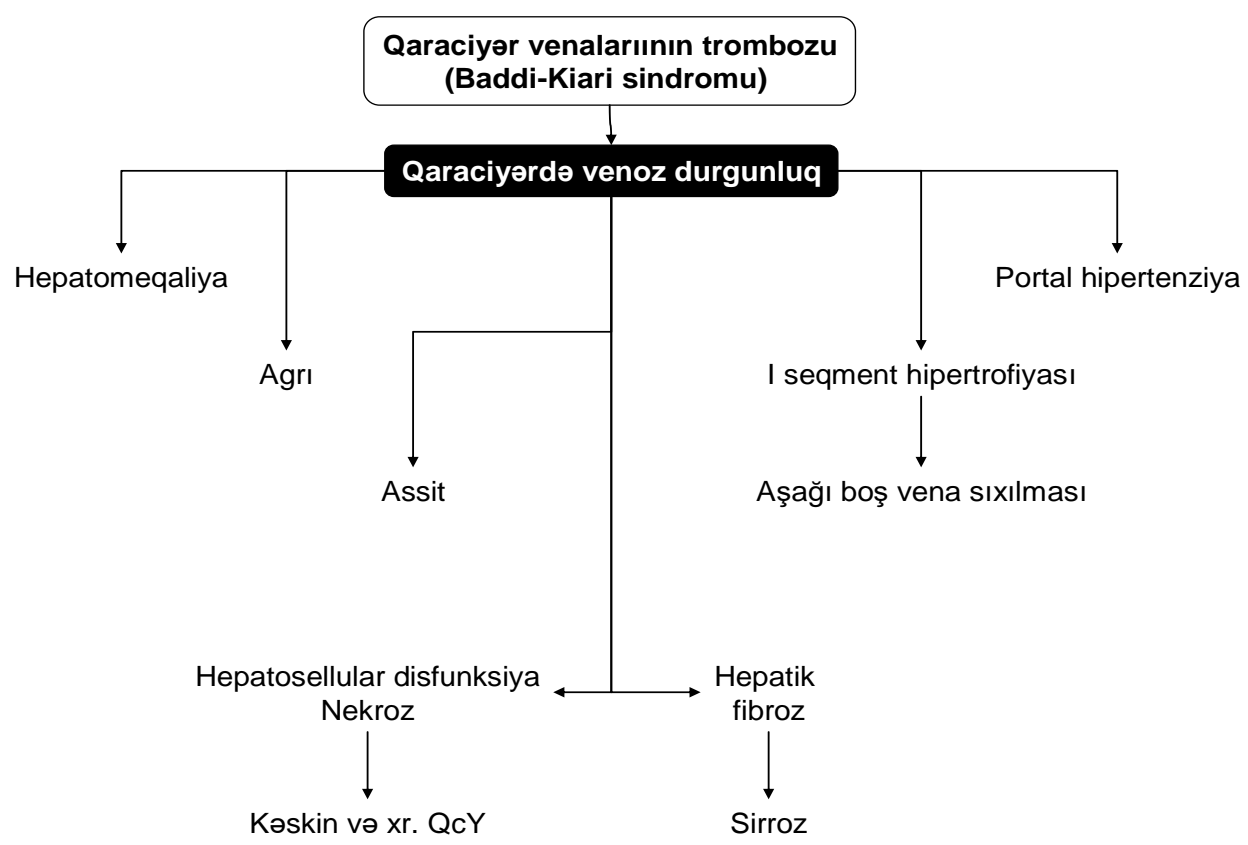

\section{Şəkil 2. Baddi-Kiari sindromunun patofiziologiyası və gedişi}

Xronik formalı xəstələrdə əsasən assit, portal hipertenziya əlamətləri ön plana çıxır. Bunlarda birinci seqment hipertrofiyası, hətta sirroz əlamətləri görünə bilir.

Asimptomatik forma adətən təsadüfi müayinələrdə tapılır. Bu xəstələrin müayinəsində Qc venalarının birinin kompensator genişlənməsi və geniş kollateral damarlar təyin edilir. Bu formanın sirroza keçmə ehtimalı var, lakin çox azdır.

Qeyd etmək lazımdır ki, Baddi-Kiari sindromu ilə yanaşı aşağı boş vena tıxanması olarsa xəstədə aşă̆ boş vena sindromu adlanan əlamətlər də ortaya çıxır: ətraflarda şişkinlik, kaval tipli kollaterallar və s.

\section{DİAQNOSTİKASI}

Kəskin qanın ağrısı, ağrılı hepatomeqaliya və assit Baddi-Kiari sindromuna şübhə yaradır (Şəkil 3). Bu əlamətlər riskli xəstələrdə (trombofiliyal1, kontraseptiv qəbul edən qadınlar, hematoloji xəstəliklər və s.) olarsa şübhə daha da artır.

Diaqnozu dəqiqləşdirmək üçün Qc venaları yoxlanılmalıdır. Venaların açıq olması və qan axınının olması diaqnozu inkar edir və bu xəstələrdə sağ ürək yetməzliyini, perikarditi, miksomanı araşdırmaq lazımdır. 


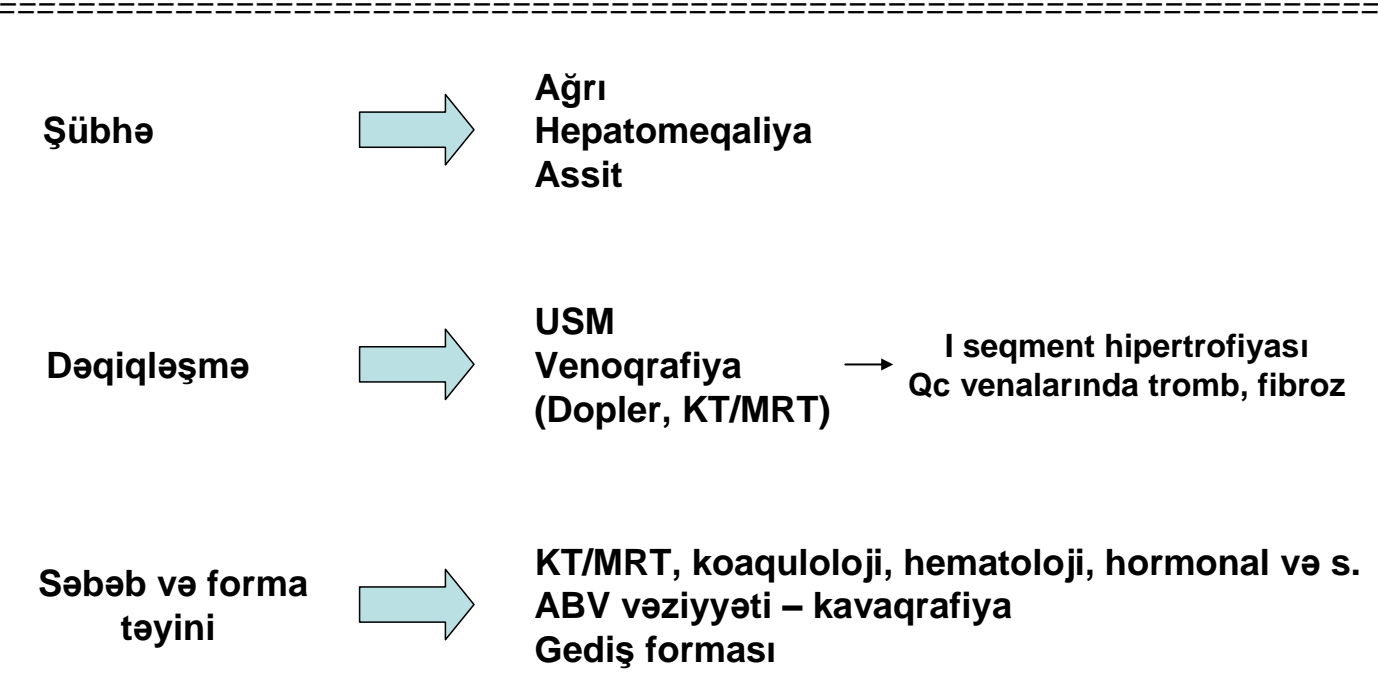

Şəkil 3. Baddi-Kiari sindromunun diaqnostikası

Qc venalarının trombotik tutlması Baddi-Kiari sindromunu təsdiq edən asas alamətdir. Baddi-Kiari sindromunun digər xarakterik əlaməti I seqmentin hipertrofiyasıdır ki, bu da əsasən xroniki formada görünür.

Qc venalarının müayinəsi üçün müxtəlif üsullar mövcuddur: kontrastlı venoqrafiya, dopler USM, KT və ya MRT-angioqrafiyalar. Qeyri-invaziv və dəqiq üsul kimi USM ilk seçimdir. Tomoqrafik üsullar ətraf orqanların vəziyyətini qiymətləndirmək üçün vacibdir.

Diaqnoz dəqiqləşdikdən sonra səbəbin axtarışı, Qc-in vaziyyəti və ən vacib olan məsələlərdən biri kimi, aşağı boş venada tıxanma olub olmadığ araşdırılır. Klinik və laborator göstəricilər Qc-in funksional vəziyyətini, tomoqrafiya isə morfoloji vəziyyətini təyin etməyə imkan verir. Hematoloji və immunoloji testlərlə digər xəstəliklər araşdırılır. Aşağı boş venanın dəqiq müayinəsi üçün KT və ya MPT angioqrafiya istifadə edilə bilər. Lakin, müalicə imkanlarını da nəzərə alaraq, kontrastlı punksion kavoqrafiya ən çox tövsiyə olunan üsuldur.

\section{MÜALİCəSI}

Baddi-Kiari sindromunun müalicəsi üç əsas prinsip üzərində qurulur:

- Osas xəstəliyin müalicəsi

- Qc-də geriyədönməz dəyişiklikləri qabaqlamaq üçün venoz durğunluğu azaltmaq 
- Ağırlaşmaların müalicəsi

Osas xəstəliyin aradan qaldırılması və ya nəzarət altına alınması Baddi-Kiari sindromunun müalicəsi üçün ilkin və vacib şərtdir. Bunlar həyata keçirilərsə sindromun inkişafinı qabaqlamaq mümkündür. Oks halda, bilavasitə sindroma yönəlmiş müalicələr effektsiz və ya mənasız olur. Baddi-Kiari sindromu olan və asas xəstวliyi müalicə olunan və ya nəzarət altına alınan xəstələrdə cərrahi müalicə ön planda tutulmalıdır. Çünki həm qaraciyərdə venoz durğunluğu azaltmaq, həm də geriyədönməz Qc zədələnməsinin müalicəsi üçün ən effektiv üsul corrahi metoddur.

\section{Venoz durğunluğu azaltma}

$\mathrm{Bu}$ məqsədlə cərrahi, endovaskulyar yanyollar mövcuddur. Porto-kaval yanyol əməliyyatı ən effektivdir və bu xəstələrdə əməliyyatdan sonra ensefalopatiya az rast gəlir. Lakin, aşağı boş vena trombozu və membranı olan xəstələrdə mezo-atrial yanyol (mezenterik vena ilə sağ qulaqcıq arasında yanyol) istifadə edilə bilər. Ancaq bu yanyol tezliklə tromboza uğradığı üçün geniş tövsiyə edilmir. Ona görə də, bu xəstələrdə endovaskulyar və ya açıq üsulla aşağı boş vena genişləndirilməsi (balon dilatasiyası, transatrial barmaq dilatasiyası) edərək porto-kaval yanyol qoyulması daha məqsədə uyğundur. Endovaskulyar yan-yol (QDPKYY) Qc venaları tıxalı olduğu üçün həmişə mümkün olmur və çox təcrübəli klinikalarda yerinə yetirilə bilir.

\section{Ağırlaşmalar və ya nəticələrin müalicəsi}

Baddi-Kiari sindromunun ən ciddi ağırlaşması kəskin qaraciyər yetməzliyi və sirrozdur. Hər iki ağırlaşmanın da effektiv müalicəsi Qc transplantasiyasıdır. Portal hipertenziyanın və ağırlaşmalarının müalicəsi əvvəlki bölümlərdə verilmişdir. Qeyd etmək lazımdır ki, konservativ müalicələr müvəqqəti simptomatik xarakter daşıyır. Qc-də venoz durğunluğu aradan qaldırılmaq, geriyə dönməz prosesləri qabaqlamaq və portal hipertenziyanı azaltmaq üçün ən faydalı üsul PKYY sayılır. 


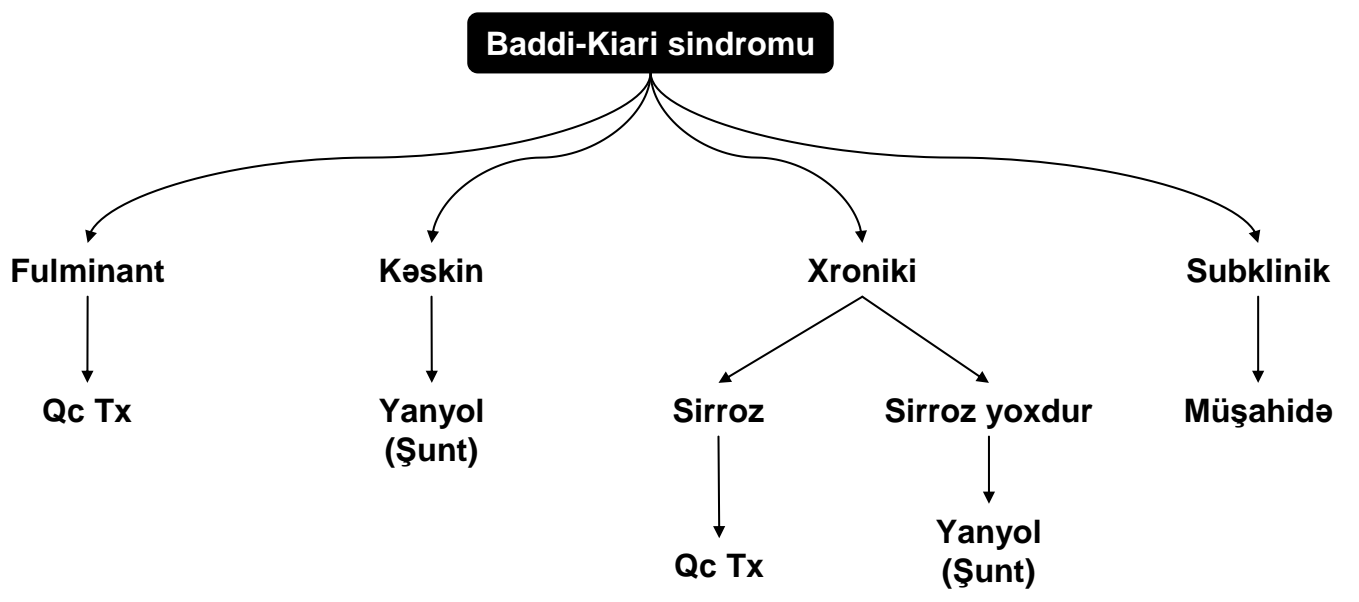

Şəkil 4. Baddi-Kiari sindromunda müalicə taktikası

\section{Müalicə taktikası}

Müalicə yolunun seçilməsində əsas göstəricilər xəstəliyin gediş forması, ABV tıxanmas1 və qaraciyərin vəziyyətidir (Şəkil 4).

Fulminant formada ən effektiv müalicə Qc transplantasiyasıdır.

Kəskin formada PKYY ilk seçimdir. Bu məqsədlə total, hissəvi və ya selektiv yanyol əməliyyatlarından biri seçilə bilər. ABV-da tıxanma varsa yanyol əməliyyatından əvvəl və ya birlikdə endovaskulyar və ya cərrahi genişləndirmə lazımdır (sonuncu daha effektivdir). Đgər ABV genişləndirilməsi mümkün deyilsə mezo-atrial yanyol istifadə edilə bilər.

Xroniki formada qaraciyərin və ABV-nın vəziyyəti nəzərə alınaraq müalicə üsulu seçilir. Qc sirrozu meydana gəlibsə transplantasiya ən doğru seçimdir. Qc funksiyası saxlanılan hallarda PKYY qoyulur.

Asimptomatik formada izləmə tövsiyə olunur.

Beləliklə, Baddi-Kiari sindromu olan xəstədə əsas xəstəlik müalicə oluna və ya nəzarət altına alına bilirsə, cərrahi müalicə ilk planda tutulur: fulminant və sirroz olduqda Qc transplantasiyası, kəskin və qaraciyər funksiyası saxlanılan xronik formada PKYY, ABV tıxanması varsa PKYY ilə birlikdə venanın endovaskulyar və ya cərrahi genişləndirilməsi, asimptomatik formada isə izləmə məsləhət görülür. 


\section{Osas adobiyyat}

1. Ăgayev B.A. Corrahi Xəstəliklər. Bakı 2001

2. Blumgart LH. Surgery of the Liver, Biliary tract and Pancreas. 4th ed. 2006

3. Cuschieri SA. Disorders of the liver. Module 10, p 321-374. in Cuschieri SA, Steel RJ, Moossa AR. Essentiale Surgical practice.. $4^{\text {th }} \mathrm{ed} .2002$

4. Feldman M, Friedman LS, Sleisenger MH. Sleisenger and Fordtran's Gastrointestinal and Liver diseases. $7^{\text {th }}$ ed. Vol II, 2002.

5. Modern Surgical Care. 2 ed. Vol I, 1998

6. Oxford textbook of Surgery V.1,2004

7. Rob and Smith's Hepatobiliary and Pancreatic Surgery. 2. ed. 1996

8. Sabiston. Textbook of Surgery 17 ed., 2006, p.1112-1143

9. Timothy DS, Steven AC. Liver. Chapter 30, p 1139-1186. in Schwartz"s Principles of Surgeryl8th ed., 2004

10. Thomas JN, Gordon AH. Pathophysology. International edition. 3th ed. P 369396, 2004

11. Sherlock S, Dooley J. Disease of the liver and biliary tract. 11-th ed. 2001

12. Sultanov H.A. Carrahi Xastaliklar. Bakı 2000

13. Surgical Anatomy and Embriology. Surgical Clinics of North America Vol 73, no 4, 1993

14. William RJ. Liver and Portal venouse system. In: Gerard MD, Lawrence WW, Current Surgical Diagnosis and Treatment. $12^{\text {th }}$ edition, 2006, p 539572

15. Zudema GD. Shackelford's Surgery of Alimentary tract, Vol III, 5th ed, 2006

\section{Olava adobiyyat}

1. Bayraktar Y, Harmanci O. Etiology and consequences of thrombosis in abdominal vessels. World J Gastroenterol. 2006 Feb 28;12(8):1165-74

2. Bargallo X, Gilabert R, Nicolau C, Garcia-Pagan JC, Ayuso JR, Bru C. Sonography of Budd-Chiari syndrome. AJR Am J Roentgenol. 2006 Jul;187(1):W33-41

3. Cauchi JA, Oliff S, Baumann U, Mirza D, Kelly DA, Hewitson J, Rode H, McCulloch M, Spearman W, Millar AJ. The Budd-Chiari syndrome in children: the spectrum of management. J Pediatr Surg. 2006 Nov;41(11):1919-23.

4. Dumortier J, Graber I, Gincoul R, Lot M, Pilleul F, Pourriol L, MettonFicarelli S, Hedelius F. Resolution of Budd-Chiari syndrome with anticoagulant treatment. Gastroenterol Clin Biol. 2006 Feb;30(2):327-8.

5. Fejfar T, Safka V, Hulek P, Vanasek T, Krajina A, Jirkovsky V. MELD score in prediction of early mortality in patients suffering refractory ascites treated by TIPS. Vnitr Lek. 2006 Sep;52(9):771-6.

6. Keshava SN, Kota GK, Mammen T, Jeyamani R, Moses V, Govil S, Kurian G, Chandy G. Direct intrahepatic cavo-portal shunts in Budd-Chiari 
syndrome: Role of simultaneous fluoroscopy and trans-abdominal ultrasonography. Indian J Gastroenterol. 2006 Sep-Oct;25(5):248-50

7. Kamath PS. Budd-Chiari syndrome: Radiologic findings. Liver Transpl. 2006 Nov;12(11 Suppl 2):S21-2

8. Klein AS. Management of Budd-Chiari syndrome. Liver Transpl. 2006 Nov;12(11 Suppl 2):S23-8

9. Larrousse C, Brasseur P, Bissen L, Sukkarieh F, Gouat F. Hepatic amebic abscess complicated by Budd-Chiari syndrome. JBR-BTR. 2006 MayJun;89(3):140-1

10. Martinelli P, Maruotti GM, Coppola A, Agangi A, Paladini D, Grandone E, Di Minno G. Pregnancy in a woman with a history of Budd-Chiari syndrome treated by porto-systemic shunt, protein C deficiency and bicornuate uterus. Thromb Haemost. 2006 Jun;95(6):1033-4

11. Plessier A, Sibert A, Consigny $Y$, Hakime A, Zappa M, Denninger MH, Condat B, Farges O, Chagneau C, de Ledinghen V, Francoz C, Sauvanet A, Vilgrain V, Belghiti J, Durand F, Valla D. Plessier A, Sibert A, Consigny Y, Hakime A, Zappa M, Denninger MH, Condat B, Farges O, Chagneau C, de Ledinghen V, Francoz C, Sauvanet A, Vilgrain V, Belghiti J, Durand F, Valla D. Aiming at minimal invasiveness as a therapeutic strategy for BuddChiari syndrome. Hepatology. 2006 Nov;44(5):1308-16.

12. Piersigilli F, Auriti C, Seganti G. Budd-Chiari syndrome and factor V Leiden in a neonate. N Engl J Med. 2006 Aug 3;355(5):527-8

13. Senzolo M, Cholongitas E, Davies N, Marelli L, Shusang V, Patch D, Burroughs AK. Transjugular Intrahepatic Portosystemic Shunt (TIPS), the preferred therapeutic option for Budd Chiari syndrome associated with portal vein thrombosis. Am J Gastroenterol. 2006 Sep;101(9):2163-4;

14. Valla DC. Prognosis in Budd Chiari syndrome after re-establishing hepatic venous drainage. Gut. 2006 Jun;55(6):761-3

15. Yamada T, Tanaka K, Ogura Y, Ko S, Nakajima Y, Takada Y, Uemoto S. Surgical techniques and long-term outcomes of living donor liver transplantation for Budd-Chiari syndrome. Am J Transplant. 2006 Oct;6(10):2463-9

16. Zimmerman MA, Cameron AM, Ghobrial RM. Budd-Chiari syndrome. Clin Liver Dis. 2006 May;10(2):259-73.

17. Zhang XM, Li QL. Radical surgery under genuine direct vision for the treatment of Budd-Chiari syndrome. Hepatobiliary Pancreat Dis Int. 2006 Feb;5(1):65-9. 
Seminar 11

\section{VENO-OKLUZIV XəSTӘLİK VӘ DURĞUNLUQ HEPATOPATIYASI}




\section{VENO-OKLUZIV XəSTӘLIKK(VOX)}

Veno-okluziv xəstəlik qaraciyər sinusoidləri və kiçik venulaların zədələnməsi tromboz və fibrozu nəticəsində ortaya çıxan venoz durğunluqdur. Bir çox kliniki əlamətlərinə görə Baddi-Kiari sindromuna bənzəsə də, səbəblərinə və gedişinə görə ondan fərqlənir. Bu barədə əvvəlki bölümdə məlumat verilmişdir.

\section{Səbəbləri}

VOX-un əvvəllər toksik səbəblərdən ortaya çıxdığı bildirildi. Lakin, son illər bu xəstəliyin ən çox rast gələn səbəbi sümük iliyi transplantasiyası (SİT) hesab olunur. Bundan başqa, kimyaterapiya, radioterapiya, pirrolizidin tərkibli bitki istifadəsi VOX törədə bilir.

\section{Gedişi}

Qeyd edildiyi kimi, VOX klinik olaraq SİT-dən sonrakı ilk iki həftə ərzində kəskin şəkildə ortaya çıxır. Xəstəliyin təbii gedişi tam dəqiqləşməyib. İlkin məlumatlara görə xəstələrin təxminən yarısı yaxşılaşır, üçdə birində Qc yetməzliyi və ölüm, onda birində isə xronikləşmə baş verir. Xronik forma sirroz və ya Baddi-Kiari (hepatomeqaliya, assit, portal hipertenziya) əlamətləri ilə büruzə verir.

\section{Klinikası}

Kəskin VOX sarılıq, hepatomeqaliya, assit, qarın ağrısı ilə ortaya çıxır. Ağır hallarda ensefalopatiya və koaqulopatiya görünə bilər. Transaminazalarda artım qeyd edilir, assit eksudativ ola bilər. Xronik forma hepatomeqaliya və təkrarlayan assit şəkilində seyr edir.

\section{Diaqnozu}

Hepatomeqaliyası, ağrısı, assiti olan və risk qrupu sayılan xəstələrdə (SİT, yüksəə doza radioterapiya, kimyaterapiya, transplantasiya keçirmiş xəstələr) VOX şübhəsi yaranır. 
Bu xəstələrdə ilk növbədə Baddi-Kiari sindromunu və ürək problemlərini inkar etmək lazımdır. Hepatik venaların açıq olması Baddi-Kiari sindromunu inkar edir, Qc venlalarının və $\mathrm{ABV}$-nin geniş görünməsi kardioloji problemə şübhə yaradır.

VOX diaqnozunu dəqiqləşdirmək üçün effektiv metod yoxdur. Porto-kaval təzyiq fərqinin $>10 \mathrm{~mm} \mathrm{Hg}$ st. olması xəstəlik üçün xarakterikdir.

Oksər xəstələrdə VOX ilə xolangiolit (toksik və ya immun) arasında diferensasiya aparmaq lazım gəlir. Hər iki halda da, xolestaz, transaminaza artımı, hepatomeqaliya görünür. Portal hipertenziya daha çox VOX üçün, yüksək dərəcəli xolestaz isə, xolangiolit üçün xarakterikdir. Bu iki xəstəlik eyni xəstədə rast gələ bilər. Son illər VOX diaqnostikasında sintoqrafik və bəzi laborator (tip 3 protollagen) göstəricilərin faydalı olduğu bildirilir.

Diaqnostik çətinlik varsa ən faydalı üsul biopsiyadır. Kəskin xəstəlikdə sinusoid və venulalarda tıxanma, intimal hiperplaziya, nekroz, xarakterikdir. Xronik fazada fleboskleroz, rekanalizasiya, arxitektonika dəyişikliyi görünür.

\section{MÜALİCOSİ}

Hazırda VOX-un qəbul edilmiş (standart) müalicəsi yoxdur. Səbəbi aradan aqldırmaq, sitotoksiklərin və radioterapiya dozalarını azaltmaq mühümdür.

VOX-un müalicəsi üçün ursodezoksixol turşusu, heparin, t-PA, prostoqlandin, qabexat mesilat kimi dərmanlar tövsiyə edilməkdədir. QDPKYY refrakter assitdə və artan sarılıqda istifadə edilir. Bəzi müəlliflər Qc Tx məsləhət görürlər.

Beləliklə, VOX-in standart effektiv müalicəsi olmadığı üçün yeni araşdırmalarına ehtiyac var.

\section{DURĞUNLUQ HEPATOPATIYYASI}

Durğunluq hepatopatiyası suprahepatik ABV-də qan axının əngəllənməsi nəticəsində qaraciyərdə baş verən venoz durğunluqdur. Bu xəstəlik ədəbiyyatda müxtəlif adlarla qeyd edilir: kardiak sirroz, kardiak fibroz, kardio-hepatik sindrom və s. Durğunluq 
hepatopatiyası üçün xarakterik əlamət hepatomeqaliya, fibroz, assit, ABV sindromunun digər əlamətləri və hepatik venaların açıq olmasıdır.

Durğunluq hepatopatiyasının ən çox rast gələn səbəbləri sağtərəfli ürək yetməzliyi, konstruktiv perikardit və aşağı boş venanın suprahepatik obstruksiyasıdır. Venaətrafı törəmələr (şişlər, yırtıqlar, qida borusu genişlənməsi) ABV-ni sıxaraq, qatlayaraq və ya venadaxili membran və tromb mənfəzi tutaraq axını əngəlləyə bilər.

Durğunluq hepatopatiyası səbəbin xarakterindən asılı olaraq, kəskin və xroniki şəkildə ortaya çıxa bilər. Hər iki formada da dominant klinik əlamət aşă̆ boş vena sindromudur: aşağı ətraflarda, xayalarda ödem, diurezdə azalma, assit, hepatomeqaliya, hətta qarının yan divarında kollaterallar. Qaraciyərdə dəyişiklik venoz işemiya, hepatomeqaliya, fibroz və portal hipertenziya ilə xarakterikdir. Durğunluğunun inkişaf surəti və müddətindən asılı olaraq bu dəyişikliklərin intensivliyi də dəyişir.

Kəskin durğunluqda venoz işemiya, sentrolobulyar nekroz və ödemə bağlı hepatomeqaliya üstünlük təşkil edir. Nekroz və ödem baş versə də, kəskin Qc yetməzliyi az hallara rast gəlir.

Xronik durğunluqda, qaraciyər fibrozu, hepatomeqaliya və portal hipertenziya inkişaf edir, Qc funksiyalarında isə, ciddi dəyişiklik rast gəlmir. Xronik formada sirrozun inkişaf edib-etmədiyi mübahisəlidir.

Durğunluq hepatopatiyasında səbəb aradan qaldırıldıqdan sonara, aksər hallarda qaraciyardə düzalma qeyd edilir.

Durğunluq hepatopatiyası olan xəstələr adətən sağ ürək yetməzliyi, ABV sindromu və ya hepatomeqaliya, assit əlamətləri ilə müraciət edirlər. Kəskin formada Qc yumşaq, xronik formada isə, sərt olur. Assit əksər hallarda transudativ xarakterli olur. Qc laborator göstəriciləri (ALT, AST, bilirubin, albumin, PTZ və s.) əksər hallarda normal olur və ya qeyri spesifikdir. Sarılıq adətən az rast gəlir, splenomeqaliya görünə bilər. Oksər hallarda Dopler USM ilə ABV və ürək problemlərini dəqiqləşdirmək mümkün olur və əlavə müayinələrə (KT, venoqrafiya və s.) az hallarda ehtiyac yaranır. $\mathrm{Bu}$ xəstələr üçün xarakterik əlamət qaraciyər venalarının və $A B V-n ı n$ geniş, dolğun görünməsi, tənəffüs hərəkəti və ya Valsalava sınağında vena diametrinin dəyişməməsidir. Digər tərəfdən, sağ ürək yetməzliyinin digər əlamətləri də Dopler USM-də ortaya çıxır. 
Durğunluq hepatopatiyasının əsas müalicəsi səbəbin aradan qaldırılmasıdır. Durğunluğun aradan qaldırılması əksər xəstələrdə Qc-dəki dəyişikliyi azaldır: Qc kiçilir, assit aradan qalxır, portal hipertenziya və splenomeqaliya azalır.

\section{Osas ədəbiyyat}

1. Ağayev B.A. Corrahi Xəstaliklar. Bakı 2001

2. Blumgart LH. Surgery of the Liver, Biliary tract and Pancreas. 4th ed. 2006

3. Cuschieri SA. Disorders of the liver. Module 10, p 321-374. in Cuschieri SA, Steel RJ, Moossa AR. Essentiale Surgical practice.. $4^{\text {th }}$ ed. 2002

4. Feldman M, Friedman LS, Sleisenger MH. Sleisenger and Fordtran's Gastrointestinal and Liver diseases. $7^{\text {th }}$ ed. Vol II, 2002.

5. Modern Surgical Care. 2 ed. Vol I, 1998

6. Oxford textbook of Surgery V.1, 2004

7. Rob and Smith's Hepatobiliary and Pancreatic Surgery. 2. ed. 1996

8. Sabiston. Textbook of Surgery 17 ed., 2006, p.1112-1143

9. Timothy DS, Steven AC. Liver. Chapter 30, p 1139-1186. in Schwartz"s Principles of Surgery18th ed., 2004

10. Thomas JN, Gordon AH. Pathophysology. International edition. 3th ed. P 369396, 2004

11. Sherlock S, Dooley J. Disease of the liver and biliary tract. 11-th ed. 2001

12. Sultanov H.A. Carrahi Xastaliklar. Bak1 2000

13. Surgical Anatomy and Embriology. Surgical Clinics of North America Vol 73, no 4, 1993

14. William RJ. Liver and Portal venouse system. In: Gerard MD, Lawrence WW, Current Surgical Diagnosis and Treatment. $12^{\text {th }}$ edition, 2006, p 539572

15. Zudema GD. Shackelford's Surgery of Alimentary tract, Vol III, 5th ed, 2006

\section{Olavə ədəbiyyat}

1. Bairey O, Kirgner I, Yakobi M, Hamdan A, Ben-Ari Z, Shaklai M. Clinical severe hepatic venoocclusive disease during induction treatment of acute monoblastic leukemia managed with defibrotide. Am J Hematol. 2002 Apr;69(4):281-4.

2. Daly AS, Hasegawa WS, Lipton JH, Messner HA, Kiss TL. Transplantation-associated hrombotic microangiopathy is associated with transplantation from unrelated donors, acute graft-versus-host disease and venoocclusive disease of the liver. Transfus Apher Sci. 2002 Aug;27(1):312.

3. Erturk SM, Mortele KJ, Binkert CA, Glickman JN, Oliva MR, Ros PR, Silverman SG. CT features of hepatic venoocclusive disease and hepatic 
graft-versus-host disease in patients after hematopoietic stem cell transplantation. AJR Am J Roentgenol. 2006 Jun;186(6):1497-501.

4. Jones AD, Maziarz R, Gilster J, Domreis J, Deveney CW, Sheppard BC. Surgical complications of bone marrow transplantation. Am J Surg. 2003 May;185(5):481-4.

5. Lefkowitch JH. Hepatobiliary pathology. Curr Opin Gastroenterol. 2004 May;20(3):188-97.

6. Reiss U, Cowan M, McMillan A, Horn B. Hepatic venoocclusive disease in blood and bone marrow transplantation in children and young adults: incidence, risk factors, and outcome in a cohort of 241 patients. J Pediatr Hematol Oncol. 2002 Dec;24(9):746-50.

7. Senzolo M, Patch D, Cholongitas E, Triantos C, Marelli L, Stigliano R, Dhillon A, Burroughs A. Severe venoocclusive disease after liver transplantation treated with transjugular intrahepatic portosystemic shunt. Transplantation. 2006 Jul 15;82(1):132-5. 
Seminar 12

\section{PORTAL VENA} TROMBOZU 


\section{TəRIFI}

Portal venanın trombozu (PVT) qapı venasının özündə və ya böyük şaxələrində (çöz və dalaq venaları, sağ və sol Qc şaxələri) kəskin və ya xroniki şəkildə ortaya çıxan, tam və ya hissəvi trombotik tıxanmadır. Xəstəliyin əsas əlaməti PH olsa da, kəskin və tam t1xanmalarda hepatosellular disfunksiya və digər qastrointestinal əlamətlər də (venoz işemiya) görünə bilər.

Portal vena trombozu portal hipertenziyanın uşaqlarda ən çox rast gələn səbəbini ( $\sim 50 \%)$, böyüklərdə isə təxminən $10-15 \%$-nin səbəbini təşkil edir.

\section{SOBӘBLORI}

Digər venoz trombozlarda olduğu kimi, PVT müxtəlif xəstəliklər nəticəsində ortaya çıxa bilər: trombofiliya, iltihabi, infeksiyon, neoplastik və digər. Bölgəyə, yaşa, tutlma dərəcəsinə görə səbəblərin rast gəlmə tezliyi də müxtəlifdir. Asiya ölkələrində trombofiliya və infeksiyalar, Avropada iltihab və neoplazmalar üstünlük təşkil edir. Uşaqlarda ən çox rast gələn səbəb göbək venasının infeksiyasıdır, böyüklərdə isə sirroz və tibbi müdaxilələr ilk sirada durur.

Dalaq venası trombozunun ən çox rast gələn səbəbi MAV şişi və pankreatitdir. PVT üçün xarakterik cəhətlərdən biri də tibbi müdaxilələrin nəticəsində son illərdə artmasıdır. Splenektomiya edilmiş xəstələrin təxminən 5-20\%-ində (xüsusən böyük dalağı olanlarda), varikoz vena skleroterapiyası olunmuş xəstələrdə isə, 40-60\%-ində portal vena trombozu rast gəlir.

Qc-i normal olan xəstələrdə trombozun ən çox rast gələn səbəbi hiperkoaqulyasiya vəziyyətləridir.

\section{GEDİŞi}

Portal vena trombozu yerinə görə 3 şəkildə ortaya çıxır: ana portal vena (ekstrahepatik), intrahepatik şaxə və dalaq venası trombozu. Çöz venasının kəskin trombozu sərbəst şəkildə olarsa, fərqli gedişə malik olduğu üçün (bağırsağın venoz qanqrenası) bu bölgüyə aid deyil. 
Ekstrahepatik qapı venası trombozunun gedişində kəskin, kollateral, rekanalizasiya və ağırlaşma və ya retromboz mərhələlərini qeyd etmək olar. Klinik olaraq bu mərhələləri həmişə dəqiqləşdirmək mümkün olmur. Kaskin dövr trombun formalaşması ilə xarakterizə olunur. Klinik olaraq ağrı, hepatit, sarılıq, assit əlamətləri ilə büruzə verə bilir, bəzən əsas xəstəliyin əlamətləri fonunda baş verir, bəzən də asimptomatik ola bilər. Az hallarda əsas vena ilə yanaşı Qc-daxili şaxələrin yayğın trombozu olarsa ağır Qc nekrozu və kəskin qaraciyər yetməzliyi baş verə bilər.

Trombozun ardınca kollaterallar inkişaf etməyə başlayır. Kollaterallar əsasən Qc qapısında, öd kisəsi ətrafında və girdə bağ ətrafında inkişaf edir. Digər tərəfdən, mədə venaları vasitəsi ilə kollaterallar aziqos sisteminə açılır. Trombun "əriməsi”" və fibroblastların inkişafı ilə vena mənfəzində rekanalizasiya baş verir. Venanın mənfəzində çoxsaylı, əyri-üyrü kanallar meydana gəlir və portal vena kavernaşəkilli transformasiyaya uğrayır. Kollaterallar və rekanalizasiya sayəsində Qc qan axını nisbətən bərpa olunur, lakin $\mathrm{PH}$ aradan qalxmır.

Bu mərhələdə xəstələr hətta asimptomatik ola bilərlər və təsadüfi müayinələrdə splenomeqaliya, portal venanın kavernoz trasvformasiyası, mədə və QB varikozu şəkilində tapıla bilər. Lakin bu xəstələr asimptomatik olsalar da təkrari tromboza və ağırlaşmalara (varikoz qanaxma, sitopeniya və s.) meyilli olurlar. Təkrari tromboz PVT-nin xarakterik xüsusiyyətidir. Tromboz vaxtaşırı təkrarlayaraq əsas şaxələrlə yanaşı böyümüş yan şaxələri də təkrar-təkrar əhatə edə bilər. Bu xəstələrdə geniş bağırsaq varikozları rastlana və qanaya bilir.

Qc-daxili şaxələrin trombozu daha dramatik şəkildə - Qc nekrozu şəklində ortaya çıxır. Hər iki şaxənin trombozu ağır Qc yetməzliyi törədir. Belə hal sirrozda və hepatosellular karsinomada çox rast gəlir. Birtərəfli tromboz hətta şişlərin müalicəsi üçün do istifado edilir.

Dalaq venası trombozu ədəbiyyatlarda soltərəfli, hissəvi portal hipertenziya da adlanır. Osas nəticəsi splenomeqaliya, mədə fundal varikozların inkişafı, hipertenziv qastropatiya və qanaxmadır.

\section{DİAQNOSTIKASI}


Portal trombozun kəskin dövrdə diaqnostikası həmişə asan olmur, adətən əsas xəstəliyin əlamətləri ilə üst-üstə düşür. Lakin bəzi əlamətlər, xüsusən birdən-birə sarılıq, assit və splenomeqaliyanın ortaya çıxması, Qc enzimlərinin kəskin artması PVT-yə yüksək şübhə yaradır. Stabil seyr edən sirrozda, HSK-da, müdaxilələrdən sonra (splenektomiya, skleroterapiya), septik xəstələrdə, infeksiyalarda xəstədə kəskin sarılıq, assit, splenomeqaliya, hətta mədə-bağırsaq qanaxması PVT-yə şübhəni artırır. Xroniki fazada (rekanalizasiya, kollaterallar) adətən zəif assit, splenomeqaliya, dispepsiya əlamətlri ola bilər. Bəzən təsadüfi (USM, KT) müayinələrdə Qc qapısında kollateral inkişafı, splenomeqaliya, endoskopik qastro-ezofageal varikozlar görünə bilər.

PVT-nin ağırlaşmaları arasında varikoz qanaxma, hipersplenizm və assit ən çox rast gələnidir. Qc funksiyası saxlanılan xəstələrdə ciddi ensefalopatiya olmur.

PVT-ni dəqiqləşdirmək üçün ən həssas müayinə Dopler USM, maqnit rezonans portoqrafiya və KT-portoqrafiyadır. Bu üsullar bir-birinə yaxın dəqiqlik göstərirlər. Görüntüləmə müayinələri venanın distalında genişlənməni, tutulan hissədə trombu, kavernoz transformasiyanı, qapıda və öd kisəsi ətrafında kollateralları göstərir. Assit və splenomeqaliya dolayı əlamətlərdir.

\section{MÜALİCəSi}

PVT-nun həlledici müalicəsi - tıxanmanın aradan qaldırllması əksər hallarda mümkün olmur. Ona görə də tədbirlər əsasən PH-ın müalicəsinə yönəlmişdir. Müalicə üsulunun seçilməsində PVT-nin mərhələsi, Qc-nın funksional vəziyyəti və ağırlaşma növü əsas istiqamətvericilərdir (Şəkil 1).

Kəskin dövrdə xəstələrə antikoaqulyant müalicə tövsiyə edilsə də (təxminən 6 ay müddətində), nəticəsi mübahisəlidir. Ona görə də, əsasən dəstək müalicəsi yerinə yetirilir. Bu tövsiyə retrombozlarda da məqsədəuyğundur.

Xronik mərhələdə asimptomatik xəstələrdə müşahidə tövsiyə olunur. Bəzi müəlliflər belə xəstələrdə PH-1 azaltmaq üçün $\beta$-blokator tövsiyə edirlər. 


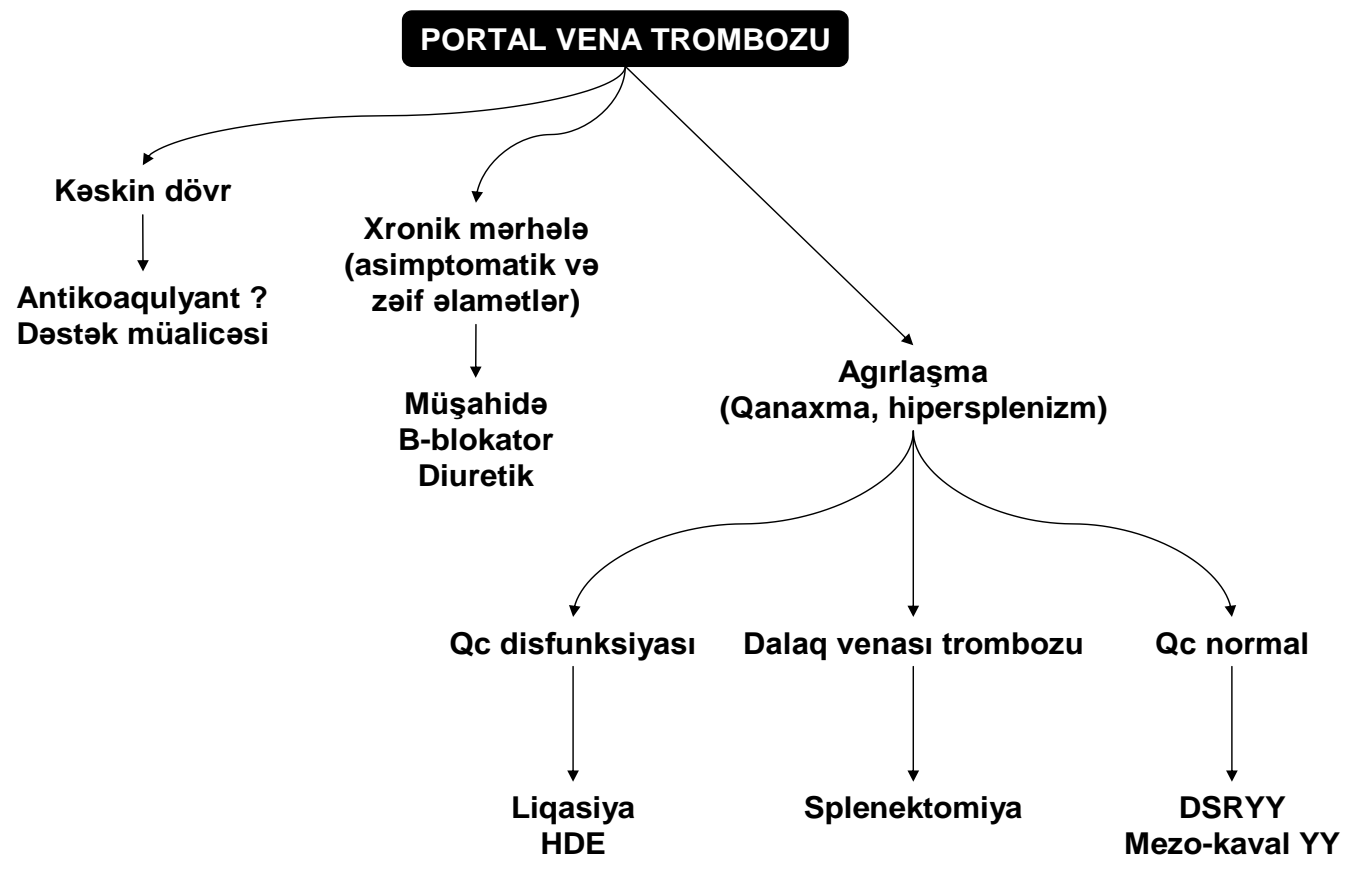

\section{Şəkil 1. Portal vena trombozunda müalicə taktikası}

Ağırlaşmalar - qanaxma və ya hipersplenizm meydana gələn xəstələrdə müdaxiləyə ehtiyac yaranır. Varikoz qanaxmada ümumi prinsiplərə uyğun olaraq ilkin müalicə tədbirlari (farmakoloji, endoskopik) ilə qanaxma dayandırılır. Sonra dekompressiya proseduraları həyata keçirilir. Soltərəfli PVT-də (dalaq venası trombozunda) ən effektiv müalicə splenektomiyadır. Bəzi

müəlliflər belə hallarda hissəvi dalaq arteriyası embolizasiyası da tövsiyə edirlər. Ana portal vena trombozunda Qc funksiyası saxlanılan xəstələrdə PKYY əməliyyatı ilk seçənək sayılır. Bu məqsədlə DSRYY ilk seçimdir. Bu mümkün olmadıqda çoxsaylı yanyollar təklif edilir: mezo-kaval, mezo-portal, mezo-qonadal və s. Son illər mezoportal (çöz venası ilə sol portal vena arasında) yanyolun daha faydalı olduğu bildirilir Qc funksiyası pozulmuş xəstələrdə yanyol əməliyyatlarından qaçmaq gərəkir. Bəzi hallarda yayğın tromboza görə yanyol qoymaq üçün uyğun vena tapmaq olmur. Hətta qoyulan çalaqlar tezliklə tromboza uğrayır.

Qeyd etmək laımdır ki, qanaxması və hipersplenizmi olmayan asimptomatik PVT-də profilaktik yanyol əməliyyatı tövsiyə edilmir.

Osas adobiyyat 
1. Ağayev B.A. Carrahi Xəstaliklar. Bak1 2001

2. Blumgart LH. Surgery of the Liver, Biliary tract and Pancreas. 4th ed. 2006

3. Cuschieri SA. Disorders of the liver. Module 10, p 321-374. in Cuschieri SA, Steel RJ, Moossa AR. Essentiale Surgical practice.. $4^{\text {th }}$ ed. 2002

4. Feldman M, Friedman LS, Sleisenger MH. Sleisenger and Fordtran's Gastrointestinal and Liver diseases. $7^{\text {th }}$ ed. Vol II, 2002.

5. Modern Surgical Care. 2 ed. Vol I, 1998

6. Oxford textbook of Surgery V.1, 2004

7. Rob and Smith's Hepatobiliary and Pancreatic Surgery. 2. ed. 1996

8. Sabiston. Textbook of Surgery 17 ed., 2006, p.1112-1143

9. Timothy DS, Steven AC. Liver. Chapter 30, p 1139-1186. in Schwartz"s Principles of Surgery18th ed., 2004

10. Thomas JN, Gordon AH. Pathophysology. International edition. 3th ed. P 369-396, 2004

11. Sherlock S, Dooley J. Disease of the liver and biliary tract. 11-th ed. 2001

12. Sultanov H.A. Carrahi Xastaliklar. Bak1 2000

13. Surgical Anatomy and Embriology. Surgical Clinics of North America Vol 73, no 4, 1993

14. William RJ. Liver and Portal venouse system. In: Gerard MD, Lawrence WW, Current Surgical Diagnosis and Treatment. $12^{\text {th }}$ edition, 2006, p 539-572

15. Zudema GD. Shackelford's Surgery of Alimentary tract, Vol III, 5th ed, 2006

\section{Olavo adobiyyat}

1. Ates O, Hakguder G, Olguner M, Secil M, Karaca I, Akgur FM. Mesenterico left portal bypass for variceal bleeding owing to extrahepatic portal hypertension caused by portal vein thrombosis. $\mathrm{J}$ Pediatr Surg. 2006 Jul;41(7):1259-63.

2. Condat B, Valla D. Nonmalignant portal vein thrombosis in adults. Nat Clin Pract Gastroenterol Hepatol. 2006 Sep;3(9):505-515.

3. Feng LS, Chen XP. Combined splenocaval or mesocaval C shunt and portoazygous devascularization in the treatment of portal hypertension: analysis of 150 cases. Hepatobiliary Pancreat Dis Int. 2006 Feb;5(1):70-3.

4. Kim HB, Pomposelli JJ, Lillehei CW, Jenkins RL, Jonas MM, Krawczuk LE, Fishman SJ. Mesogonadal shunts for extrahepatic portal vein thrombosis and variceal hemorrhage. Liver Transpl. 2005 Nov;11(11):1389-94.

5. Morag I, Epelman M, Daneman A, Moineddin R, Parvez B, Shechter T, Hellmann J. Portal vein thrombosis in the neonate: risk factors, course, and outcome. J Pediatr. 2006 Jun;148(6):735-9.

6. Murad SD, Valla DC, de Groen PC, Zeitoun G, Haagsma EB, Kuipers EJ, Janssen HL. Pathogenesis and treatment of Budd-Chiari syndrome combined with portal vein thrombosis. Am J Gastroenterol. 2006 Jan;101(1):83-90.

7. Ogren M, Bergqvist D, Bjorck M, Acosta S, Eriksson H, Sternby NH. Portal vein thrombosis: prevalence, patient characteristics and lifetime risk: a population study based on 23,796 consecutive autopsies. World J Gastroenterol. 2006 Apr 7;12(13):2115-9.

8. Romano F, Caprotti R, Scaini A, Conti M, Scotti M, Colombo G, Uggeri F. Elective laparoscopic splenectomy and thrombosis of the spleno-portal axis: a prospective study with ecocolordoppler ultrasound. Surg Laparosc Endosc Percutan Tech. 2006 Feb;16(1):4-7.

9. Superina RA, Alonso EM. Medical and Surgical Management of Portal Hypertension in Children. Curr Treat Options Gastroenterol. 2006 Sep;9(5):432-443.

10. Svensson M, Wiren M, Kimby E, Hagglund H. Portal vein thrombosis is a common complication following splenectomy in patients with malignant haematological diseases. Eur J Haematol. 2006 Sep;77(3):203-9.

11. Stamou KM, Toutouzas KG, Kekis PB, Nakos S, Gafou A, Manouras A, Krespis E, Katsaragakis S, Bramis J. Prospective study of the incidence and risk factors of postsplenectomy thrombosis of the portal, mesenteric, and splenic veins. Arch Surg. 2006 Jul;141(7):663-9.

12. Superina R, Bambini DA, Lokar J, Rigsby C, Whitington PF. Correction of extrahepatic portal vein thrombosis by the mesenteric to left portal vein bypass. Ann Surg. 2006 Apr;243(4):515-21. 